teresa cristina toledo de paula

\title{
Inventando moda e costurando história: pensando a conservação de têxteis no museu paulista/usp
}

Dissertação apresentada como exigência parcial para obtenção do grau de Mestre em Ciências à Comissão Julgadora da

Escola de Comunicações e Artes da Universidade de São Paulo, sob orientação da Profa Dra Maria Helena Pires Martins

Escola de Comunicações e Artes

Universidade de São Paulo 1998 
Comissão Julgadora: 
muito obrigada a:

\title{
Maria Helena Pires Martins
}

Murillo Marx

Teixeira Coelho

Waldisa Rússio Camargo Guarnieri (i.m.)

\author{
FAPESP \\ MUSEU PAULISTA - USP \\ SAMUEL H. KRESS FOUNDATION \\ THE TEXTILE CONSERVATION CENTRE \\ VITAE
}

\author{
Dinah Eastop \\ Gláucia Amaral \\ Janey Cronyn \\ Joaquim Tarquinio Wieth \\ Marco Ferretti \\ Paul Auster \\ Tatá
}




\title{
RESUMO
}

Este ensaio apresenta as principais idéias e metodologia que têm orientado os trabalhos de Conservação de Têxteis Históricos no Museu Paulista da Universidade de São Paulo.

Através dessa discussão específica, todavia, é repensado o papel da conservação/restauração de bens culturais frente à sensibilidade, atitude e ideário deste fim de milênio.

\begin{abstract}
This paper presents the main ideas and method which have been guiding the textile conservation works at Museu Paulista, Universidade de São Paulo.

Through this specific discussion, however, the author reconstructs the role of conservation/restoration of cultural heritage related with the sensibility, atittude and ideas brought by the end of the millennium.
\end{abstract}


"Há quem sempre estude, sem nunca aprender. Há quem aprenda sem nunca ter estudado. E há quem se beneficie tanto do que lê quanto do que sente. Claude pertencia ao último grupo, era o tipo de artesão que Diderot duvidava existir: erudito e prático, filosófico e habilidoso. Pois se Diderot punha pouca fé na capacidade intelectual do artesão, Claude punha pouca fé em Diderot. O editor da Encyclopédie descrevia, mas não fazia...."

Allen Kurzweil, Uma caixa de curiosidades. 
conteúdo

introdução

\section{capítulo 1}

mudando de idéia, mudando a idéia: a conservação do importante....10

capítulo 2

introduzindo uma necessidade: a idéia de patrimônio têxtil....29

capítulo 3

inventando moda e costurando história -

pensamento e trabalho prático....71

\section{capítulo 4}

reflexões possíveis sobre um trabalho em construção....167

a bibliografia comentada.....192 


\section{conclusão}

anexo

documentação do Estudo de Caso 10: desenhos digitais....240

\section{introdução}

Este ensaio apresenta as principais idéias e metodologia que têm orientado os trabalhos de Conservação de Têxteis Históricos no Museu Paulista da Universidade de São Paulo. Através dessa discussão específica, todavia, é repensado o papel da conservação/restauração de bens culturais frente à sensibilidade, atitude e ideário deste fim de milênio.

O trabalho foi desenvolvido com a seguinte estrutura formal: quatro capítulos, bibliografia comentada e um anexo.

No primeiro capítulo discutimos o que entendemos por conservação de bens culturais, as principais idéias associadas à atividade hoje, e introduzimos, já, 
algumas questões como o exagero e o politicamente correto, desenvolvidas nos capítulos seguintes.

No segundo capítulo três questões principais são discutidas: os reflexos do pensamento politicamente correto nas atividades de conservação; a transformação paulatina do perfil profissional de restaurador-artista para conservador-cientista; e por último a idéia de que um exagero crescente caracteriza a atividade de preservação em nossos dias.

No terceiro capítulo comentamos a natureza específica da atividade de conservação de têxteis históricos. As características da tipologia, assim como a ética e a teoria específicas antecedem a apresentação de dez estudos de caso desenvolvidos no Museu Paulista da USP.

No quarto capítulo encontram-se discutidas as possíveis peculiaridades dos trabalhos de conservação num contexto universitário específico: a Universidade de São Paulo.

Seguem-se aos capítulos a apresentação de toda a bibliografia utilizada, comentada caso a caso, e um Anexo no qual são apresentados os desenhos digitais complementares a um dos estudos de caso discutidos no capítulo 3. 
capítulo 1

mudando de idéia, mudando a idéia:

a conservação do importante 
Tantas coisas acontecem sem que ninguém fique sabendo nem recorde. De quase nada há registro, os pensamentos e movimentos fugazes, os planos e os desejos, a dúvida secreta, os sonhos, a crueldade e o insulto, as palavras ditas e ouvidas, depois negadas, ou mal entendidas, ou deformadas, as promessas feitas e não levadas em conta, nem mesmo por aqueles a quem foram feitas, tudo se esquece ou prescreve, o que se faz a sós e não se anota, e também quase tudo o que não é solitário mas em companhia, quão pouco vai ficando de cada indivíduo, de quão pouco há registro, e desse pouco que resta tanto se cala, e do que não se cala se recorda depois tão-somente uma mínima parte, e por pouco tempo, a memória individual não se transmite nem interessa a quem a recebe que forja e tem sua própria. Todo tempo é inútil. mim.

Javier Marías Amanhã, na batalha, pensa em

Escrever ou discutir sobre conservação de bens culturais, quase sempre, significa repetir as idéias que já na década de 1950 H.J. Plenderleith apresentava 
em trabalho pioneiro ${ }^{1}$. De lá até hoje - em uma primeira consideração -, diríamos que cada matiz - seja do conceito seja da atividade profissional -, já foi discutido e reafirmado dezenas de vezes e em vários idiomas.

Podemos afirmar que a atividade de conservação, neste final de milênio, encontra-se segura de suas metas e ciente de seus desafios. Se outros momentos históricos foram caracterizados pela expectativa de conhecimento e/ou tecnologia futuras que trouxessem melhores opções de trabalho, este nosso tempo apresenta-se como aquele do usufruto de tais condições: dispomos, hoje, de segurança, conhecimento e tecnologia para trabalhar. E talvez apenas por estarmos vivendo um momento assim tão favorável é que uma antiga questão tenha podido retornar: será que tudo isso importa?

Quase sempre as críticas que encontramos ao trabalho museológico aqui ou no estrangeiro, de modo geral, advêm de pessoas externas ao meio profissional imediato, ou mesmo, de não simpatizantes à instituição museu. É incomum encontrarmos uma literatura crítica consistente em qualquer uma das áreas museológicas e, especialmente, na de conservação. Os profissionais de conservação, tradicionalmente, ocuparam-se mais em discutir com competência os critérios, meios, técnicas e problemas físico-estruturais que se lhe foram apresentados, do que em pensar e repensar a natureza de sua atividade e a extensão de seu sentido num contexto social mais amplo.

A intenção deste capítulo introdutório - e do ensaio como um todo -, não é a de exatamente inovar o conceito de conservação, mas explicitá-lo, localizando-o no tempo e no espaço. Se quisermos produzir um pensamento novo ou diferenciado, ao menos, precisamos antes bem compreender o ideário

\footnotetext{
${ }^{1}$ H.J.Plenderleith THE CONSERVATION OF ANTIQUITIES AND WORKS OF ART: TREATMENT, REPAIR AND RESTORATION, London: Oxford University Press, 1956. 373p.il.
} 
que se assume e postula como correto e/ou conveniente ao mundo e às pessoas desse mundo ${ }^{2}$.

Preservar o planeta, preservar o verde, preservar os animais, preservar o patrimônio! Nunca antes, por certo, as idéias de preservação e extinção estiveram tão presentes em nosso cotidiano. Estamos chegando ao fim do milênio, imersos em uma ética que acredita que o nosso mundo- tal como o pensamos e o queremos, - não sobreviverá, ou não valerá a pena, sem as coisas e idéias que consideramos essenciais. Podemos pensar nesse momento histórico, também, como aquele do viajante que precisa planejar e escolher aquilo que levará consigo na bagagem: objetos, idéias e sentimentos, um pouco de tudo que o represente, que o identifique, que o localize no tempo e no espaço. Algo que contenha o seu gosto, seu modo de viver e ilustre seu projeto de felicidade.

Muito já se escreveu sobre a necessidade humana de construir uma cultura, uma memória e sobre querer preservá-las. E muito, também, já se viu e ouviu do contrário. O que se teria modificado, todavia, em cada momento histórico e em cada sociedade seria o grau de adesão, o número de pessoas

\footnotetext{
2 Esta é uma tendência do momento atual. Vários personagens do mundo da conservação/restauração tem produzido textos com estas preocupações; é o caso de Paul Philippot, diretor do ICCROM (International Centre for the Study of the Preservation and the Restoration of Cultural Property), que em texto recente apresentou as seguintes considerações: "When one examines the evolution of the concept of restoration in the professional literature and colloquia, one sees that interest in this type of question has grown in recent years. Simultaneously, the nature of these concerns has been clarified appreciably, to the point that today we may speak unequivocally of conservation as a discipline that is based on method, whereas formerly it was a profession resting on no more than empirical knowledge. In the context of such a change, the relationships that have arisen between two components of modern conservation - that which is relevant to the humanities and that which is relevant to technique and the exact sciences - merit very special attention." Paul Philippot "Restoration from the Perspective of the Humanities" APUD: Nicholas Stanley Price et alli (ed.) HISTORICAL AND PHILOSOPHICAL ISSUES IN THE CONSERVATION OF CULTURAL HERITAGE. (Readings in Conservation) Los Angeles: The Getty Conservation Institute, 1995, 500 p., p.216.
} 
que compunham um ou outro grupo. Ontem não se pensava como agora e tudo indica que amanhã pensar-se-á de outra forma. Nesse rumo parece mais sábio e mais justo pensarmos nosso tempo atual como um momento dessa discussão.

A idéia de preservação traz com ela, necessariamente, dois tempos distintos, senão três: um tempo passado, um tempo presente e um tempo futuro ou, ao menos, presente e futuro: preservamos alguma coisa hoje, de hoje ou de ontem, para alguém hoje e amanhã. Se concordamos que preservar é proteger, pôr ao abrigo de algum mal, dano ou perigo futuro, é defender e resguardar, concordamos, também, que só o fazemos porque o fazemos para alguém ou seja: nós, hoje, julgamos que isto ou aquilo deve permanecer, deve continuar existindo porque é importante e, assim, agimos no sentido de preserválo para alguém, hoje e amanhã.

Os anos 90 trouxeram consigo novas idéias e propostas para o fim do milênio. A ecologia, o politicamente correto, o respeito ao "diferente" e ao natural, influenciaram as idéias de preservação tal qual fizeram com tudo o mais no mundo. A idéia menos é mais ${ }^{3}$ passou a permear o discurso de preservação nos museus mundo afora. Um novo ideário- baseado em atitudes menos intervencionistas, pouco químicas de preservação,- passou a predominar nas práticas de trabalho e nos modos da preservação ${ }^{4}$. Podemos afirmar que os modos da preservação são diversos. A rigor toda atividade que contribua ou resulte na preservação de um bem cultural pode ser pensada enquanto um modo da preservação. Este capítulo, entretanto, limitar-se-á a discutir apenas um desses modos: a conservação.

\footnotetext{
${ }^{3}$ a expressão original, inglesa, é less is more.

${ }^{4}$ Toda vez que uma definição de termo for introduzida no texto, este aparecerá em itálico e/ou grifado.
} 
Muitos autores, de diferentes épocas, nacionalidades e culturas, já definiram e redefiniram os termos conservação e restauração. Acredito, mesmo, que quase tudo já tenha sido dito e pensado sobre estes termos. Aqui neste trabalho, portanto, estaremos adotando uma determinada idéia de conservação e restauração- dentre as muitas possíveis ,- idéia esta que afirma o seguinte: "a conservação tem como objetivo manter a integridade física e visual de um objeto, removendo-lhe elou acrescendo-lhe o mínimo de material. A restauração tem uma ordem diferente de prioridades: o aspecto visual ou funcional é predominante. Seu objetivo é recriar, ( no objeto), a aparência visual e física que se acredita tenha ele originalmente exibido." 5 A diferença básica entre os dois modos de preservação, percebe-se, está no objetivo da ação ${ }^{6}$ : tratemos de compreender, portanto, o que se entende ou se imagina, hoje, por conservação de bens culturais.

A conservação de bens culturais apresenta-se, hoje, como uma atividade científica e não como uma ciência. As novas tecnologias, a pesquisa dos diferentes materiais, a melhor compreensão dos processos de degradação, aliados à uma ética e à uma visão de mundo do profissional conservador e da instituição que ele representa ${ }^{7}$, juntos, é que formam a atividade de conservação ${ }^{8}$.

\footnotetext{
${ }^{5}$ Mary Brooks, Caroline Clark, Dinah Eastop e Carla Petschek "Restauração e conservação: algumas questões para os conservadores. A perspectiva da conservação de têxteis" IN ANAIS DO MUSEU PAULISTA. São Paulo, N.Ser. v.2 jan/dez 1994. p. 236. (Tradução Teresa Cristina Toledo de Paula)

6 “Parece conveniente estabelecer uma distinção entre conservação e restauração, o primeiro destinado à interrupção dos processos de degradação e o segundo aos casos em que couber um trabalho de maior interferência no original, ressalvando-se sempre o princípio da inalterabilidade da obra." Lenora Lerrer Rosenfield, GLOSSÁRIO TÉCNICO DE CONSERVAÇÃO E RESTAURAÇÃO EM PINTURA. Porto Alegre, Editora /UFRS Universidade, 1997, p.10.

7 apesar de sabermos que hoje, cada vez mais, cresce o número de profissionais conservadores privados, ou seja, que não trabalham dentro de uma instituição determinada, estaremos pensando, neste texto, nos profissionais de museus e naqueles que trabalham com museus.
} 
Esta atividade encontra-se organizada, internacionalmente, desde 1930 quando se realizou, em Roma, a primeira conferência internacional de conservação 9 . Atualmente as principais idéias e experiências de trabalho em conservação - mais no exterior do que no Brasil, - refletem as discussões surgidas nos congressos e/ou encontros promovidos pelas principais organizações internacionais de conservação: ICOM-CC ${ }^{10}$ (Comite de Conservação do ICOM), ICCROM (Centro Internacional para Preservação e Restauração de Bens Culturais), IIC (Instituto Internacional de Conservação), AIC (Instituto Americano de Conservação) UKIC (Instituto de Conservação do Reino Unido) e SSCR (Sociedade Escocesa para Conservação e Restauração). Além destas organizações, merecem especial destaque as atividades e publicações desenvolvidas pelo Canadian Conservation Institute, sediado em Ottawa, e pelo The Getty Conservation Institute sediado em Marina Del Rey, Estados Unidos. Vários museus, também, possuem equipes de conservadores cuja opinião acaba, sempre, por influenciar toda a coletividade da conservação. São

8 esta idéia, de uso corrente, aparece definida por Konstanze Bachmann na introdução de Conservation Concerns. A guide for collectors and curators.Nova York, Cooper-Hewitt National Museum of Design- Smithsonian Institution, 1992.

${ }^{9}$ Konstanze Bachmann, op.cit., p. 1 . Segundo afirma a A., seguiram-se a este encontro, do ponto de vista formal, o ICOM (International Council of Museums), fundado em 1946, na França; o IIC (International Institute of Conservation), em 1950, em Londres, e o AIC (American Institute for Conservation) formado em 1973.

${ }^{10}$ O Comitê de Conservação encontra-se subdividido, atualmente, em vinte três grupos de trabalho que possuem jornais específicos e, eventualmente, promovem simpósios temáticos. São eles: 1. Conservação Preventiva; 2. Formação em conservação/restauração; 3. Teoria e História da Restauração; 4. Exames Científicos das obras de arte; 5. Documentação; 6. Pintura I- conservação e restauração de pinturas; 7. Pintura II - Estudo científico de pinturas: métodos e técnicas; 8. Escultura e policromia; 9. Pinturas murais, mosaicos e arte rupestre; 10. Documentos gráficos; 11. Registros fotográficos; 12. Coleções Etnográficas; 13. Materiais orgânicos e arqueológicos submersos; 14. Têxteis; 15. Couro e materiais afins; 16. Coleções de História Natural ; 17. Pedra; 18. Vidro, cerâmica e materiais afins; 19. Metais; 20. Materiais laqueados; 21. Mobiliário e objetos em madeira; 22. Resinas: caracterização e avaliação; 23. Materiais modernos. 
exemplos as equipes: da National Gallery, British Museum e Victoria \& Albert Museum na Inglaterra; dos Museus da Smithsonian nos Estados Unidos e do Laboratoire de recherche des Musées de France, França.

Podemos afirmar que a atividade de conservação no lado ocidental do mundo, hoje, encontra-se construída sobre as seguintes idéias: A) o fim do mito da reversibilidade; B) o respeito ao objeto e interferência mínima; C) a necessidade de uma ética nos trabalhos; D) a importância da conservação preventiva $^{11}$.

O fim do mito da reversibilidade. Durante muito tempo, até a década de 1980, aproximadamente, toda a atividade de conservação e restauração pautou-se sobre a idéia da reversibilidade. Segundo essa idéia todo trabalho de intervenção realizado sobre um objeto, quer de conservação quer de restauração, deveria ser reversível, ou seja: tudo aquilo que fosse realizado por um profissional, hoje, teria que poder ser removido por outro profissional amanhã. Por exemplo: Suponhamos que um museu tivesse em seu acervo uma mesa do século 19, sem uma das pernas. No local da perna faltante, apenas resíduos da cola utilizada. O trabalho de intervenção na mesa - nesse caso a feitura e colocação de uma nova perna -, deveria ser reversível, ou seja: deveria ser exaustivamente documentado e passível de ser removido caso a nova perna colocada, no futuro, fosse considerada inadequada por alguma razão.

Durante décadas este tipo de atitude profissional foi entendida como a mais adequada, a mais ética e, mesmo, como a única tolerada nas instituições museológicas e órgãos de preservação. Mas na década de 1980, entretanto, essa

\footnotetext{
${ }^{11}$ É importante termos em mente que as idéias discutidas, aqui, são particularmente válidas no nosso lado do mundo. As especificidades culturais são determinantes na área museológica. Um mesmo objeto, por exemplo, poderá ser analisado de forma bastante diferenciada por um profissional brasileiro, por um profissional indiano ou por um profissional neo-zelandês.
} 
idéia começou a ser questionada e foi substituída pela afirmação de que nada é reversível, ou seja: não há modo de voltar atrás; o que foi modificado, modificado está. Com esta mudança radical no pensamento das atividades da área, todos os procedimentos de trabalho passaram a ser questionados e/ou reformulados e, a partir dessa premissa, podemos dizer, surgiram as outras que discutiremos a seguir. ${ }^{12}$

O respeito ao objeto e interferência mínima. O fim da crença no princípio da reversibilidade colocou novas questões a curadores, museólogos e/ou conservadores de museus. Há muito já se pensava um objeto como testemunho material de alguma coisa ou idéia, mas foi na década de 1980, sem dúvida, que surgiram vários textos comentando o assunto ${ }^{13}$. A idéia de que cada

\footnotetext{
${ }^{12}$ Aqui cabe um esclarecimento: a reversibilidade ainda é um critério utilizado e válido na conservação/restauração. O que terminou, por assim dizer, foi a crença de que era possível voltar-se atrás $100 \%$ numa intervenção sobre um objeto qualquer.

${ }^{13} \mathrm{Um}$ dos principais porta-vozes desse comportamento criterioso por parte do profissional conservador foi Hanna Jedrzejewska, profissional polonesa, que têm vários ensaios publicados sobre o assunto. Diz a A. : "o conceito básico fundamental é que os objetos antigos, a despeito de seu tipo, idade, dimensões e valor, são antes e acima de tudo, documentos do passado. E que sua maior importância é o fato de fornecerem informações sobre a história e o desenvolvimento do homem.(...) Todos os tipos de evidência, sejam primários ou secundários podem fornecer informações sobre materiais usados, técnicas de produção, tipos de design e suas formas artísticas e tantos outros detalhes únicos que caracterizam cada objeto. (...) Nos objetos antigos, essa evidência pode estar presente apenas de forma fragmentária. Às vezes, apenas alguns traços seus podem ser encontrados, e o conservador tem que se fazer quase de detetive para localizá-los. Aqui é importante frisar o seguinte: um documento somente se conservará como tal enquanto mantiver sua autenticidade. Um documento precisa ser autentico. Esta é sua definição essencial. Nos objetos antigos, autenticidade significa a existência de características originais, primárias, não só em relação aos materiais brutos de que são feitos, mas também em face das características humanas já citadas. Somente essa espécie de evidência terá importância enquanto assunto de estudos futuros. A questão é que o tratamento de conservação significa uma interferência direta na "essência" do objeto, e isso pode significar que características importantes correm o risco de perder-se." Hanna Jedrzewska, Problems of ethics in the conservation of textiles, IN: CONSERVAZIONE E RESTAURO DEI TESSILI: CONFERENCIA INTERNAZIONALE. Como: 1980, pp. 99-103. Este texto foi traduzido por nós em 1994, do original em inglês, para integrar a apostila do nosso primeiro curso de difusão ministrado no Museu Paulista: Introdução à Conservação e Restauração de Têxteis Históricos.
} 
objeto é único trouxe à discussão, também, as noções de cópia, imitação, falsificação e autenticidade. Afinal, passou-se a perguntar, o que diferencia um objeto restaurado de uma falsificação? A diferença estaria no processo de trabalho ou na maneira como o resultado é apresentado ao público, depois de pronto $?^{14}$ Os profissionais que até então atuavam sobre os objetos com a segurança de estarem apenas contribuindo para a sua preservação se deram conta, assim, de que por muitas vezes - mesmo sem o desejarem - estavam removendo, daqueles objetos, uma série de informações que nunca mais seriam recuperadas. Desse modo tornou-se consenso, hoje em dia, a idéia do menos é mais, da interferência mínima.

A necessidade de uma ética nos trabalhos. Vejamos as seguintes afirmações: "os objetos, por definição, são diferentes e cada caso é um caso" e "cada cultura tende a interpretar seus acervos segundo critérios próprios". Baseados nestas idéias e no que foi colocado até aqui surge, inevitavelmente, a pergunta: como podemos, então, garantir que todos os profissionais de museus trabalhem sob as mesmas idéias e normas de conduta? A resposta é simples, não podemos. E se não podemos, como determinar, então, o que é certo, o que é ético? Afinal, nos últimos anos, todos falam em ética, seja em conservação seja em sociedade, política ou esporte. Falar em ética virou moda $!^{15}$ Mas o que significa trabalho ético em conservação?

As diversas associações e organizações de conservação já citadas, desenvolveram ou aprimoraram, nos últimos anos, códigos de ética e sugestões de procedimentos de trabalho para seus membros. A intenção nunca foi a de vigiar ou punir nenhum profissional, mas, sim, garantir uma uniformidade na

\footnotetext{
${ }^{14}$ Esta idéia é apresentada por Mary Brooks et alli em texto já citado, p. 236.

${ }^{15}$ Mais uma vez verificamos que as idéias de preservação, vigentes agora, estão em sintonia direta com o que acontece mundo afora.
} 
abordagem dos mesmos problemas. A maior parte dos códigos, apesar de algumas diferenças regionais, considera ético o trabalho de conservação realizado sob os seguintes princípios básicos: 1. priorização dos valores documentais do objeto; 2. pesquisa prévia e documentação exaustiva de qualquer intervenção; 3. ação de modo a fazer apenas o necessário; 4. uso de todo o conhecimento disponível sobre o assunto; 5.uso, apenas, de materiais de qualidade comprovada; 6 . habilitação técnica e intelectual para desenvolver o trabalho que se pretende, não correndo riscos de nenhuma natureza.

Estes princípios básicos, norteadores, contudo, costumam ser interpretados de maneira diferente conforme as necessidades e problemas específicos de cada tipologia de objeto. Isto significa que o conceito de mínimo necessário, por exemplo, será muito diferente se aplicado a um trem, a um vestido ou a um lustre ${ }^{16}$. Acima de qualquer outra idéia, o trabalho ético pressupõe seriedade profissional, informação atualizada e bom senso.

A importância da conservação preventiva. Todas essas discussões apontadas, aqui, vieram reforçar uma proposta que não era nova ou inédita: a conservação preventiva. Embora já presente há muito na literatura de conservação, esta idéia passou a ser defendida mais acirradamente, todavia, a partir da década de 1980, podendo ser considerada a idéia-chave da conservação nos anos $90^{17}$. Prevenir, planejar, evitar; pensar na conservação não somente de um ou outro objeto, mas desenvolver estratégias de preservação para as coleções e acervos como um todo. Assim

\footnotetext{
${ }^{16}$ No caso dos objetos têxteis, por exemplo, há uma série de especificidades que precisam ser consideradas: as manchas, os padrões de cores, a própria idéia de "sujeira", a manutenção de costuras etc.

${ }^{17}$ H.J.Plenderleith em seu trabalho THE CONSERVATION OF ANTIQUITIES AND WORKS OF ART: TREATMENT, REPAIR AND RESTORATION, cuja primeira edição, em Londres, data de 1956, foi um dos primeiros teóricos da área a introduzir a discussão sobre a importância do trabalho de conservação preventiva.
} 
poderíamos, quem sabe, definir o que geralmente se pensa quando se fala, hoje, em conservação preventiva. Vejamos o que disse sobre o assunto Kathleen Dardes, Coordenadora do Programa de Treinamento Avançado (Senior Training Program Coordinator) do The Getty Conservation Institute, pouco tempo atrás, durante o VII Seminário da ABRACOR (Associação Brasileira de Conservadores e Restauradores de Bens Culturais):“A noção tradicional de conservação tem se transformado nos últimos anos. Não faz tanto tempo assim que conservação significava costurar um rasgo, colar uma rachadura ou preencher uma área perdida. Conservadores e Restauradores ainda executam estas tarefas e sempre o farão, mas nosso pensamento e nossa forma de abordar estas questões, sem dúvida, evoluiu, expandiu-se. Prevenir o dano ao invés de remediar o dano, é vista hoje, mais e mais, como a principal meta da conservação. Esta mudança da ênfase- do reparo e da restauração para a prevenção -, nos obriga, enquanto conservadores, a modificar nossa visão em vários aspectos. Nós, agora, devemos adotar uma abordagem mais ampla e pensarmos no bem-estar de coleções inteiras, ao invés de pensarmos na restauração de objetos individuais que já sofreram dano. Isto requer de nós, também, uma visão de preservação das coleções a longo prazo quando formos considerar como e onde usaremos nossos recursos. (....) É significativo que, nos últimos anos, uma série de conferências e seminários internacionais sobre conservação preventiva tenham sido realizados, permitindo, assim, que todos os que trabalham na área se beneficiem das experiências de seus colegas. Este é um momento importante e entusiasmante no desenvolvimento da nossa profissão." 18.

\footnotetext{
${ }^{18}$ Kathleen Dardes. Recent Developments In Preventive Conservation In The United States. IN: SEMINÁRIO DA ASSOCIAÇÃO BRASILEIRA DE CONSERVADORES E RESTAURADORES DE BENS CULTURAIS - ABRACOR, 7, PETRÓPOLIS, 1994. Anais. Rio de Janeiro, ABRACOR, 1994, p. 46.
} 
Retomando o que já dissemos, a conservação de bens culturais, hoje, se apresenta como uma disciplina científica. É preciso que saibamos distingüir- nela e sobre ela,- aquilo que se apresenta como evento e aquilo que é interpretação que uma época ou uma cultura determinada tiveram desse evento: a deterioração dos materiais é um evento; o modo como ela ocorre (constância, ritmo, intensidade) em ambientes com altos índices de umidade relativa e temperatura, por exemplo, é interpretação. Portanto, o que importa deixar claro, aqui, é que existem fatores constantes dos quais depende a preservação dos bens culturais, fatores determinantes sobre os quais todos os profissionais envolvidos na salvaguarda das coleções precisam atuar.

Todos os fatores determinantes na conservação de bens culturais poderiam ser resumidos em uma só idéia: segurança física ${ }^{19}$. Este é o princípio norteador da conservação. No contexto museológico, institucional, uma série de relações estão em jogo: a comunicação, a educação, a documentação, a pesquisa. Cada uma dessas atividades trabalha, no museu, de modo a desenvolver suas atividades da melhor forma possível; cada qual estabelece sua prioridade, seu princípio norteador. Façamos um exercício de imaginação e pensemos como cada uma dessas atividades do museu trabalharia, separadamente, o mesmo objeto em exposição. Aqueles responsáveis pela comunicação, ou museografia, tratariam de encontrar a melhor forma de expô-lo: o melhor mobiliário, os melhores materiais, a melhor iluminação, do ponto de vista visual, estético. Os responsáveis pela documentação tratariam de prover o objeto com uma etiqueta detalhada na qual estariam contidas todas as

\footnotetext{
19 Os fatores tradicionalmente lembrados são: 1. SEGURANÇA proteção contra roubo, vandalismo, acidentes, desastres naturais, intervenções inadequadas; 2. ACESSO: EXPOSIÇÃO E ARMAZENAGEM critérios e materiais para manuseio, embalagem, exposição e guarda; 3. QUESTÕES AMBIENTAIS luz, temperatura, umidade relativa, poluição atmosférica; 4. AÇÃO DE ORGANISMOS VEGETAIS E DE ANIMAIS.
} 
informações disponíveis sobre aquela peça. Já os responsáveis pela educação estariam preocupados com o resultado pedagógico da comunicação: talvez preferissem, por exemplo, que os visitantes tocassem o objeto, que o segurassem entre as mãos. E o conservador ? $\underline{\mathrm{O} \text { conservador, muito provavelmente, optaria }}$ por não trabalhar com o objeto e pensaria em expor uma fotografia. Mas o trabalho do profissional de museu, por definição, não deveria ser uma atividade integrada, uma fusão de todas estas preocupações ?

Idealmente a prática museológica de trabalho deveria integrar equilibradamente todas as áreas citadas acima. Todas deveriam ser trabalhadas com a mesma competência e atenção. Entretanto sabemos que - por uma série de fatores- isto, na prática da maioria das instituições brasileiras, acaba não acontecendo e uma ou outra dessas atividades que deveriam, sempre, caminhar paralelas acaba por sobrepor-se às demais. Ou seja: a maioria das instituições, mesmo sem o desejar, acaba enfatizando algumas áreas do trabalho museológico em detrimento de outras tantas. Alguns trabalham desta forma por opção; outras por negligência ou ignorância.

Somos fruto do nosso tempo e o nosso tempo acredita na conservação preventiva. Não se trata de insinuar que a conservação preventiva seja uma idéia inadequada: ela é uma idéia importada como tantas outras e a expressão do ideário politicamente correto $^{20}$, acreditamos, nas práticas de conservação de bens culturais. ${ }^{21}$

\footnotetext{
${ }^{20}$ As relações entre práticas de trabalho, ética profissional e o politicamente correto serão discutidas nos próximos capítulos.

${ }^{21}$ Um bom exemplo de importação e adoção equivocada de parâmetros internacionais pode ser tirado da adesão incondicional que sempre fizemos, no Brasil, das recomendações internacionais em relação aos índices de umidade relativa e temperatura dos locais que abrigam bens culturais móveis. A recomendação estrangeira de determinados índices ambientais favoráveis à boa conservação de acervos culturais foi, sempre, pautada sobre a realidade climática do Hemisfério Norte para atender às especificidades do Hemisfério Norte. Tais índices, hoje, bastante disseminados, nada mais são do que convenções que aliam situações climáticas favoráveis à conservação da maioria dos materiais orgânicos e
} 
A importação de tendências tem sido uma característica determinante, no Brasil, nos últimos anos. O pequeno número de cursos de conservação e restauração no país e, principalmente, a ausência de uma reflexão consistente sobre a nossa realidade patrimonial, tem contribuído para que uma série de idéias estrangeiras, com endereços e filosofias diversas, muitas vezes contraditórias, se instalassem entre nós. Não há o que fazer sobre o assunto, é uma decorrência destes dias: vários profissionais brasileiros têm deixado o Brasil para se especializar em diferentes países, em escolas que trazem, naturalmente, abordagens e práticas de trabalho diferenciadas. Ao retornar, nada mais natural que reproduzam, apliquem, divulguem e ensinem aquilo que aprenderam no estrangeiro. Isto é comum em todas as áreas do conhecimento onde não existe maturidade profissional, não sendo exclusividade, portanto, da área de conservação/restauração.

Uma última questão que mereceria ser introduzida já aqui, neste primeiro capítulo, seria a da valoração maior ou menor que atribuímos às nossas coleções e, conseqüentemente à conservação de nossos acervos. Historicamente, ao menos no Brasil, os museus acompanharam as tendências do mercado de arte, ou seja: aquilo que tem mais valor financeiro-comercial, acaba "valendo mais", também, dentro do museu. Assim foi que as pinturas de cavalete e esculturas, os acervos em papel e o mobiliário, na maioria dos museus, sempre

inorgânicos, aos índices igualmente toleráveis e confortáveis às pessoas. Assim surgiram os índices tão propagados como ideais, de temperatura entre 19 e 22 graus $\mathrm{C}$ e umidade relativa entre 45 e $55 \%{ }^{21}$. Diz, também, a literatura estrangeira que, variações de umidade relativa acima de $2 \%$ (para mais ou para menos) só podem ser toleradas em um espaço de 30 dias, ou seja: seriam necessários trinta dias para que um material pudesse passar de um ambiente com 50\% de umidade relativa, para um ambiente com $52 \%$ ! Sabemos que em boa parte do Brasil é comum termos variações de umidade relativa superiores a dez pontos por dia. Não há como negar que exista um ótimo ambiental à conservação dos materiais, ou seja, uma situação climática favorável à melhor conservação dos objetos. Entretanto não há como negar, também, que, a despeito do que afirma a literatura estrangeira, - os acervos do Museu Paulista e outras instituições tropicais -, sobreviveram. 
foram pensados como núcleos principais de coleções. O restante das tipologias dos veículos à plumária, dos instrumentos musicais às rendas e brinquedos -, ocuparam, freqüentemente, um segundo plano ou mesmo um terceiro. E esta valoração de mercado, endossada pelos museus, influenciou muito nos trabalhos de conservação das coleções como um todo. Tal valoração, internamente, tratou de priorizar determinados grupos de acervo em detrimento de outros. Do mesmo modo, laboratórios de conservação foram criados, sempre, para atender às mesmas categorias de bens culturais. Basta pensarmos, por alguns minutos, em nossos poucos cursos de formação e, mesmo, na quantidade de profissionais atuando nesta ou naquela modalidade da conservação para concluirmos que, estranhamente, é o mercado de arte que ainda determina as diretrizes da preservação de bens culturais no Brasil. Parece uma afirmação estranha de se fazer; mais estranho, todavia, é não termos no país instituições museológicas - universitárias ou não -, dotadas de laboratórios com profissionais especializados na conservação de metais, de veículos, de couros e peles, de instrumentos musicais, de objetos com mecanismo, de plumária, de plásticos e materiais modernos, e tantas outras possibilidades. A simples idéia de desenvolvermos estas atividades, dentro dos museus, ainda causa estranheza, soa como novidade, tal é a forma pela qual nos encontramos habituados a pensar, hierárquica e tradicionalmente, nosso patrimônio ${ }^{22}$.

A conservação, de um modo geral, passou a ser mais enfatizada dentro dos museus nos últimos anos. Provavelmente isto possa ser explicado, mais uma vez, por aqueles fatores "fim de século"- mencionados no início deste texto e que deverão ser melhor explorados nos próximos capítulos -, mas também pela

\footnotetext{
${ }^{22}$ Curiosamente novas hierarquias estão sendo criadas. De dez anos para cá presenciamos um boom na conservação de imagens fotográficas, o que como fato museológico poderia ser
} 
necessidade real que décadas de negligência acabaram por impor às instituições, hoje. E , talvez, esse "passado negligente" possa explicar uma tendência que se apresenta nestes dias, a do exagero conservativo. $\mathrm{O}$ exagero conservativo é a prática da conservação pela conservação. É a ênfase exagerada na atividade de conservação; é a adesão à crença de que ela, conservação, representa a meta principal, contemporânea, do trabalho museológico.

Nunca se investiu tanto em conservação. Os grandes museus estrangeiros criam, a cada dia, recursos cada vez mais sofisticados para proteger seus objetos. Aparelhos sensores, vidros de vitrine que deterioram, reservas técnicas especiais à preservação de objetos de chocolate e açúcar, sistemas de iluminação por fibra ótica; são apenas alguns exemplos do que se pode encontrar mundo afora. Os museus andam exagerados; a idéia de preservação anda exagerada, e a atividade de conservação, também.

Estamos vivendo um tempo de mudanças radicais em tudo e para tudo. A era da globalização, do fim das geografias tradicionais, anda transformando rapidamente algumas das atividades museológicas e, talvez, a museologia, como um todo, não se tenha dado conta disto. De qualquer modo o exagero está presente e é preciso enxergá-lo. Sabemos que nunca teremos tempo, espaço e condição de estudar, exibir e conservar todos os objetos que estão sendo coletados. Então, cabe sempre perguntar: por quê fazemos isso $?^{23}$

bastante positivo, caso não trouxesse consigo uma nova onda hierárquica, um novo modismo: o imagético.

${ }^{23}$ Dentre as coleções pessoalmente visitadas, nos últimos anos, contabilizamos um número que ultrapassa os 10 bilhões de objetos (apenas no British Museum, Victoria \& Albert Museum, Merseyside Museums, Metropolitan, Smithsonian, Louvre ) sem calcular, aqui, livros e coleções cartográficas. Ignoramos, com certeza, quantos humanos somos, hoje. Mas pensemos que a população do planeta seja algo ao redor de 5 bilhões. Pensemos, ainda, que cada um desses objetos custe mensalmente, ao seu depositário legal, entre 50 e 100 dólares: teremos cifras e somatórias assustadoras.Esta contabilidade mundial dos acervos parece-nos um tema bastante interessante para um trabalho futuro. Desconheço qualquer publicação que se tenha ocupado de calcular quantos objetos estão sendo preservados em museus, hoje. 
Em 1997, no Textile Symposium em Ottawa, Canadá, Linda Hillyer e Jonathan Ashley-Smith, do Victoria \& Albert Museum, Londres, (chefe do Departamento de Conservação de Têxteis e chefe da Conservação, respectivamente) apresentaram comunicação questionando o trabalho desenvolvido pelo museu e que neste momento nos serve para ilustar o exagero do qual falamos:

"In the real dynamic system in which objects decay, treatments do not last forever and the museum continously interacts with its audience, the calculation of the apparent backlog for textiles objects at the $V \& A$ increases from 40 to 150 years. At the end of 40 years, even though some 40,000 treatments have taken place, the 'backlog' remains at about 150 years. If it is true that conservation treatments only last for a limited period of time, say a few decades, then it is obvious that the work can never be completed. All the objects that are treated eventually revert to the category of objects awaiting treatment." 24

Talvez seja a hora de nos perguntarmos se vale a pena, se é importante gastarmos nosso tempo e recursos em tantos objetos. Talvez seja a hora de nos perguntarmos o quê, exatamente, é importante. Falar em preservação de objetos em um mundo onde ainda se morre de fome é ao menos polêmico, para não dizer insensato. Será que a preservação de toda essa materialidade assegurar-nos-á, ao menos, a conservação de nossos projetos de felicidade, de nossa condição sensível ?

Não poderemos salvaguardar tudo. Teremos que optar, sempre, pela conservação daquilo que mais importa. Só que aquilo que mais importa não pode

\footnotetext{
${ }^{24}$ Jonathan Ashley-Smith e Lynda Hillyer- Can high productivity be productive? FABRIC OF AN EXHIBITION: AN INTERDISCIPLINARY APPROACH, Ottawa, 1997. Preprints. Ottawa, Textile Symposium 97, Canadian Conservation Institute, 1997, p.8
} 
ser determinado, apenas, pelo mercado de arte ou por um modismo de ocasião. A conservação do importante é ampla por definição, e pressupõe abrangência e eqüidade. 
capítulo 2

introduzindo uma necessidade:

a idéia de patrimônio têxtil

No capítulo anterior introduzimos algumas das idéias que, acreditamos, permeiem de modo evidente as atividades de conservação/restauração de bens 
culturais neste final de século XX. Sabemos, entretanto, que não é apenas isso. Hoje encontramos estas e outras idéias igualmente fortes e contundentes agindo na formação das sensibilidades, dos ideários, de um modo di fare bastante característico. Nossa intenção neste segundo capítulo, portanto, será discutir algumas delas, relacionando-as umas com as outras para então contextualizar o que chamamos de "introdução de uma necessidade", ou seja: a forma como foi trazida do estrangeiro e introduzida- primeiramente na Universidade de São Paulo e hoje bastante disseminada -, a idéia de que há um patrimônio têxtil a ser preservado.

\section{A filosofia do less is more: a conservação politicamente correta}

Dirt can be defined as a material which is in the wrong place, rather as a weed is thought as a plant growing in the wrong place. ${ }^{25}$

A sutil definição de sujeira - surgida na Inglaterra ainda na década de $1980^{26}$-, pode ser considerada um marco ou um forte indício das mudanças de mentalidade e práticas de trabalho que passariam a ocorrer nas diversas áreas da conservação nos anos subseqüentes ${ }^{27}$. Novas idéias em um discurso novo e

\footnotetext{
${ }^{25}$ THE CONSERVATION UNIT - SCIENCE FOR CONSERVATORS - CLEANING. London, The Conservation Unit of the Museums \& Galleries Commission/Routledge, 1992, vol 2, p.13.

${ }^{26}$ A primeira edição de Science for Conservators, em 3 volumes (Introduction to Materials, Cleaning e Adhesives, respectivamente) data de 1982. Os três volumes, essenciais às atividades de conservação/restauração, hoje, foram produzidos por Jonathan Ashley-Smith, Victoria \& Albert Museum, Londres.

${ }^{27}$ Toda a vez que mencionarmos a expressão áreas da conservação aqui neste trabalho, estaremos nos referindo às atividades e teorias praticadas pelas diversas modalidades de materialidade: têxtil, metal, materiais modernos, plumária, etc e não necessariamente à divisão formal de grupos de interesse estabelecidos pelos comitês internacionais, como os mencionados no primeiro capítulo.
} 
diferente passaram a sugerir e induzir, pouco a pouco, uma nova prática e atitude profissionais. O politicamente correto alcançava o pensamento preservacionista e lhe atribuía novos qualificativos: necessário, indispensável, transigente ${ }^{28}$, ético, passaram a ser os novos adjetivos utilizados na equação de projetos de intervenção e investigação ${ }^{29}$. Tais mudanças, aparentemente, foram ocorrendo nas diferentes áreas em ritmos e volumes bastante diferenciados: as áreas de tipologias "tradicionais", com Escola, como a pintura (mural e de cavalete), arquitetura, mobiliário e escultura relutaram, e ainda hoje relutam, muitas vezes, em repensar antigas noções. Já aquelas das artes "decorativas", materiais modernos e outras- como a área têxtil -, estruturadas mais recentemente (após 1950), parecem sempre ter se comportado de modo mais receptivo ${ }^{30}$. Ao analisarmos a bibliografia mais recente dos diversos grupos veremos que aqueles aqui chamados de "tradicionais", ainda se encontram bastante próximos das idéias de Cesare Brandi em seu Teoria del Restauro , marco na historiografia. ${ }^{31}$

A idéia de intervenção, tal qual a entendemos hoje, também é recente. Ao pontuarmos as considerações de H.J. Plenderleith, já no prefácio de The Conservation of Antiquities and Works of Art (1956), notaremos que uma

\footnotetext{
${ }^{28}$ Transigente, aqui, surge como tradução para compromised.

${ }^{29}$ Um "projeto de intervenção e investigação" na área de conservação significa o mesmo que um "tratamento"- modo como freqüentemente se conhece e denomina, fora da Universidade, o planejamento e desenvolvimento de um processo de conservação sobre um objeto.

${ }^{30}$ É interessante notarmos uma outra possibilidade de leitura da adesão dessas diferentes áreas às novas propostas. De um modo geral, as áreas consideradas mais conservadoras em conservação/restauração, parecem corresponder àquelas dos objetos que precisam "ficar em pé”, ou seja, daqueles cujo sentido de existência, de preservação, é unívoco em sua proposta estrutural, ou seja: diferentemente de um fragmento de cerâmica ou de parte de um vestido, um mural, uma cadeira, ou uma pintura de cavalete só podem ser apresentados no exercício de sua função, desconsideradas aqui é claro, as releituras e propostas das artes moderna e contemporânea.

${ }^{31}$ Cesare Brandi , TEORIA DEL RESTAURO. Torino, Einaudi, 1977, 6ed.
} 
série de ações sobre os objetos hoje consideradas já o próprio trabalho de intervenção, eram concebidas somente como medidas preliminares ao trabalho conservativo propriamente dito: "As collectors know only too well, the acquisition of objects is but the first step towards their incorporation in the collection. In order to be able to appreciate and study the objects, it is usually necessary to clean, restore and always maintain a suitable environment which will ensure their stability whether in storage or on exhibition. In the following chapters simple instructions are given for cleaning and preservation, and the collector with a practical mind who desires to carry out for himself the methods described can do so without any special technical training.

Cesare Brandi e H.J. Plenderleith - assim como William Morris e Alöis Riegl o foram até meados do século $\mathrm{XX}^{33}$, podem ser considerados os polarizadores do pensamento e da geografia nas quais se desenvolveram os principais trabalhos e pensamento de conservação/restauração desde o pósguerra. Teoria e prática, respectivamente, explicitaram as posturas profissionais, indagações e propostas que vigiram até a década de 1980, aproximadamente, época em que a reversibilidade deixou de ser paradigma e ganharam força outras idéias até então menos consideradas, conforme apresentamos no capítulo anterior $^{34}$. As mudanças verificadas daqueles para estes dias são sobretudo de

\footnotetext{
${ }^{32}$ H.J. Plenderleith, op.cit., Prefácio, vii.

33 William Morris (1834-1896), inglês, fundador da Society for the Protection of Ancient Buildings, em 1877, para a qual escreveu seu Manifesto.

Aloïs Riegl ( 1858-1905 ), professor da Universidade de Viena e presidente da Comissão dos Monumentos Históricos austríacos, autor de Le culte moderne des monuments, foi pioneiro na reflexão sobre o conceito de monumento, suas significações não explícitas e diferentes valores a eles atribuídos.

${ }^{34} \mathrm{O}$ trabalho de Plenderleith pode ser considerado a primeira tentativa de sistematização científica de procedimentos técnico-práticos da conservação/restauração. $\mathrm{O}$ autor, cientista
} 
forma e grau: os procedimentos propriamente ditos, quando levados à frente, hoje, são bastante semelhantes aos praticados nos anos 50, obviamente excluindo-se desta afirmação os aprimoramentos advindos das novas condições mercado-tecnológicas.

Sabe-se que o pós-guerra trouxe à Europa, principalmente, o sentimento de "é preciso fazer" em todas as áreas nas quais reparos e restauração se faziam necessários ${ }^{35}$. Também não podemos esquecer o imenso trabalho dos museus durante e após a Segunda Guerra (Louvre, British, Victoria\&Albert), quando a quase totalidade das coleções foi transferida e escondida em subterrâneos e/ou fora das capitais como medida de proteção ${ }^{36}$. Havia muito trabalho a ser feito, poucos profissionais habilitados, portanto. No texto de Plenderleith fica evidente a preocupação do autor em ser claro, em facilitar o acesso à informação e à execução de trabalhos. Naquele contexto de mundo eram raros os especialistas e

do Laboratório de Pesquisa do British Museum, reconhecia em seu trabalho a necessidade de orientar e informar curadores e profissionais de conservação não só sobre aquelas áreas chamadas aqui de tradicionais, mas igualmente a respeito de todas as outras tipologias de objeto.

${ }^{35}$ A imagem de Rosie the Riveter, arregaçando as mangas sob os dizeres "WE CAN DO IT", apesar de anterior, parece bem ilustrar este sentimento de "mãos à obra" do qual falamos.

${ }^{36}$ Plenderleith - no capítulo dedicado ao estudo das condições ambientais, chega a citar os danos ocorridos às coleções devido às mudanças para os esconderijos: "Before the Second World War a technician was employed for eight months in the year to deal with such defects in pictures at the National Gallery where the atmosphere was not conditioned. On the other hand, in the repository which housed the same pictures during the war and where the air was conditioned to 58 per cent. R.H. at $63 \mathrm{~F}$. the work of the technician was reduced to approximately one month during the first year, progressively less in the following years, and finally after five years his visits became a mere formality as there was no longer anything for him to do. The significance of the relative humidity factor in the conservation of pictures was further emphasized by the fact that, when the pictures were returned to London, they behaved in the same way as before the war, the paint flaking off as badly as ever in rooms that were not air-conditioned.

Similarly, in a large repository used during the war to house the British Museum and Victoria and Albert Museum collections (antiquities, books, textiles, prints, drawings, furnitures, \&c.), the air was controlled at the constant figures 60 per cent.RH.at $60 \mathrm{~F}$., and not a single case of deterioration was recorded in this repository." Plenderleith, op.cit., p. 4. 
outras as preocupações, portanto; acreditava-se na reversibilidade e na positividade da conservação/restauração, ou seja, toda e qualquer iniciativa sobre um objeto era interpretada como um ganho, um passo em direção à sua preservação.

Tais trabalhos encontraram no texto de Cesare Brandi o suporte teórico necessário às intervenções pretendidas. Todos os conceitos e princípios básicos apresentados, embora relacionados diretamente à Arquitetura, acabaram por influenciar e determinar as abordagens metodológicas das outras tipologias materiais. Brandi retoma as discussões do século XIX sobre restauração ou não restauração, ampliando as idéias de ruína ${ }^{37}$, autenticidade e intervenção ${ }^{38}$.

Plenderleith, diferentemente, teve como principal preocupação arrolar os procedimentos práticos necessários aos trabalhos de intervenção. E neste contexto interessa-nos, sobretudo, o modo como isso se deu. Vejamos os seguintes trechos do capítulo que o autor dedicou aos têxteis:

\footnotetext{
37 "A ruin is anything that is a witness to human history. Its appearance, however, is so different from the one it originally had that it becomes almost unrecognizable...... Consequently, the preservation of a work of art that is reduced to a state of ruin depends to a great extent on the historical significance that is assigned to it....... When dealing with ruins, restoration can only be a consolidation and preservation of the status quo." Theory of Restoration, APUD: Nicholas Stanley Price et alli, op. cit., p. 233.

38 "If we thus come back to the alternatives of conservation or removal from a visual, historical perspective, we will consider it appropriate, whenever possible, to return a monument to that state of imperfection in which it had been left by the historical process and which ill-considered restorations have instead completed. However we should always respect the new unity that, independently of the foolishness of restorations, was established within the work of art through a new fusion, the more this fusion affects the work of art is also a real source of historical material and testimony............ One can point out, nonetheless, that even the worst reconstruction does, in fact, document human activity, albeit an erroneous one, and that it is still part of human history. Thus it should not be removed - at the most it can be isolated. This position would seem to be historically unassailable if it did not, in fact, lead to a conviction for the entire work of art. Such a conviction would lead us to question the very veracity of the monument as a historical monument: this cannot be allowed at the level of philological critique. Furthermore, a similar requirement to completely conserve all phases through which the work of art has passed must not contradict the aesthetic requirement."

Ibidem p. 235.
} 
1. "Before begining restoration work on textiles the first step is to carry out an examination...It may be impossible to record all particulars until the textiles have been washed, but is important to get as much information as possible in the first place in case any evidence should be lost during treatment. The preliminary examination will decide what are the safest methods to adopt for cleaning and restoration.” 39

2. "There are three general ways of protecting textiles from insects. The first is to isolate the textile-to parcel it up so that insects cannot get at it. The second is to use insecticides, and the third is to use an inhibitor that is either so disasteful to the insect or so toxic that protection is assured. This last method involves the use of a proofing reagent that can be permanently fixed on the textile fibre. This necessitates the use of special apparatus and is a technique that can only be applied to new material in the course of manufacture. “ 40

3. "Apart from vacuum fumigation that can be applied on a large scale to protect costumes or ethnographical material in bulk, the most effective protection is given by the presence of a volatile insecticide such as dichlorobenzene, which, though perhaps a trifle too volatile, is otherwise satisfactory and efficient. “ 41

Talvez seja difícil ao leitor externo à área de conservação entender o quão estranho, radical e mesmo inadmissíveis soem hoje, ao profissional contemporâneo, as recomendações fornecidas pelo autor. Tomemos alguns pontos para discussão. A primeira observação que pode ser feita, por exemplo,

\footnotetext{
${ }^{39}$ Plenderleith, op.cit.p. 94

${ }^{40}$ Ibidem p. 114.
} 
diz respeito a quantidade de ações propostas, no sentido em que mencionamos antes: lavar, limpar, aplicar ou seja: fazer, executar, agir. A nossa filosofia do less is more, politicamente correta de hoje em dia, praticamente nos impossibilita de compreender ou considerar sério um trabalho que mencione explicitamente um agir contundente e/ou um risco de percurso como o apontado na citação 1 ou, ainda, a pouco preocupada recomendação para o uso de produtos químicos como o diclorobenzeno, na citação 3.

O less is more impôs aos profissionais uma postura sobretudo de observação. Antes de qualquer ação é preciso observar, observar muito, exaustivamente, exageradamente. Nos museus de história e etnografia tudo pode ser considerado importante, preservável, documento. Um simples fio de cabelo depositado sobre um paletó pode ser encarado como um documento valioso $^{42}$. O comportamento profissional mudou da ação para a observação. Agir somente quando necessário: é melhor prevenir do que remediar, afirma o discurso profissional vigente, politicamente correto. Tal abordagem da cultura material, acreditamos, encontrou na conservação preventiva ${ }^{43}$ o modo de reintroduzir o discurso da anti-restauração, tão propagado por John Ruskin no século $\mathrm{XIX}^{44}$. No momento atual nada parece justificar uma ação radical, definitiva, que gere arrependimento.

\footnotetext{
${ }^{41}$ Plenderleith, p. 115

${ }^{42}$ Em 1998 foi encontrado um fio de cabelo sobre um smoking que pertenceu a Santos Dumont. O procedimento por nós adotado foi o de identificá-lo e encaminhá-lo ao setor responsável pela documentação. Um simples fio de cabelo, se submetido hoje a um exame de DNA, por exemplo, talvez possa trazer uma série de informações sobre o personagem e esclarecer melhor seu envelhecimento e morte prematuros.

${ }^{43}$ Conservação Preventiva aqui entendida como uma série de práticas que objetivam proteger os objetos e retardar seu processo de degradação.

${ }^{44}$ "Do not let us talk of restoration. The thing is a lie from begining to end....But, it is said, there may come a necessity for restoration! Granted. look the necessity full in face, and understand it on its own terms. It is a necessity for destruction. Accept it as such, pull the building down, throw its stones into neglectd corners, make a ballast of them or mortar, if
} 
Tratando-se da conservação de objetos provenientes de culturas outras que não a dos profissionais do museu depositário, por exemplo, há ainda um forte apelo antropológico e/ou etnográfico no sentido do respeito às diferenças culturais, às diferentes formas de enxergar e interpretar o mundo. Textos como o de Kahlemberg (1986), e o de Orlofsky (1993), autores americanos, enfatizam suas análises na demonstração dos limites da interpretação durante o estudo e conservação dos objetos $^{45}$.

Aqui talvez seja o momento de introduzirmos uma observação. As considerações gerais que vêm sendo feitas e boa parte das que serão feitas neste ensaio, têm como objeto de discussão as atividades desenvolvidas em determinados grupos de países: os americanos, os euro-ocidentais mais Austrália e Nova Zelândia. Não estão sendo considerados aqui, portanto, países como Japão, India e Irã- dentre outros -, que apresentam um outro modo de pensar as questões preservacionistas.

Há todavia, hoje, um grupo de países cujo trabalho permanece diferenciado. Esse grupo- ao menos na área têxtil,- é formado pelos países escandinavos (mais a Holanda) e os leste-europeus. Nesses países, ideário e

you will; but do it honestly, and do not set up a Lie in their place. And look that necessity in the face before it comes, and you may prevent it... Take proper care of your monuments, and you will not need to restore them." John Ruskin(1819-1900), The Seven Lamps of Architecture (1849). APUD: Nicholas Stanley Price et alli, op. cit., p. 322.

${ }^{45}$ Kahlenberg, ao narrar a trajetória de um Pua -tecido cerimonial produzido em Bornéu -, sugere que os profissionais de museus conheçam melhor o histórico dos objetos com os quais lidam, antes de abordá-los e/ou submetê-los a algum tratamento de conservação e/ou modo expositivo. Mesmo afirmando que todo objeto de museu é necessariamente resemantizado, a autora sugere uma nova atitude por parte dos profissionais de museu. KAHLENBERG, Mary Hunt. Collecting considerations. In: TEXTILE CONSERVATION SYMPOSIUM. Los Angeles: Los Angeles County Museum of Art, 1986. p. 54-57. No mesmo sentido escreve Orlofsky, enfatizando que a formação do profissional (background) será definitiva no encaminhamento e/ou direcionamento dos trabalhos de conservação a serem executados. ORLOFSKY, Patsy; TRUPIN, Deborah Lee. The role of connoisseurship in determining the textile conservator's treatment options. JOURNAL OF THE AMERICAN INSTITUTE FOR CONSERVATION v.32, n.2, p. 109-118, 1993. 
procedimentos de trabalho parecem não ter sido permeados pelo discurso e atitude politicamente corretas. Desconhece-se ou mesmo ignora-se a idéia da intervenção mínima. Um bom exemplo são os trabalhos recentes apresentados em uma conferência internacional em Estocolmo $(1997)^{46}$; quando assinados por profissionais daquela geografia, eles se assemelham bem mais às idéias e práticas postuladas por Plenderleith na década de 1950 do que às publicações ocidentais atuais. Contudo este é um grupo delimitado cuja tendência, acreditamos, será adotar, pouco a pouco, os procedimentos da maioria institucionalizada e participante dos foros internacionais de discussão. Mas retornemos à idéia anterior, insistindo um pouco mais em ilustrar a conservação politicamente correta.

Em 1993 o Departamento de Conservação do British Museum, Londres, organizou o seminário Restoration - Is it acceptable ?, cujas discussões, posteriormente publicadas, apontaram o entendimento que as diversas áreas da conservação vêm tendo a respeito de seus procedimentos de trabalho ${ }^{47}$. As dezenove comunicações apresentadas sobre tipologias bastante diferenciadas (relógios, instrumentos musicais, mural, madeira, tapetes, tecidos, armaduras, veículos, computadores e mosaicos) evidenciaram as preocupações do momento: intervenção mínima, trabalho ético, limites de ação. $\mathrm{O}$ trecho abaixo, de autoria do organizador do encontro, é um bom exemplo do modo atual, politicamente correto, como vêm sendo discutidas as temáticas da conservação:

"Cleaning is generally understood as the revelation of detail by the removal of surface dirt and concretion. But it is always right (ethically

${ }^{46}$ SFT SILK CONFERENCE, Estocolmo, 1997. Preprints. Estocolmo, Svenska Föreningen för Textilkonservering (SFT), 1997. 70p. il.

${ }^{47}$ RESTORATION. IS IT ACCEPTABLE ? BRITISH MUSEUM CONFERENCE, London, British Museum, 1994, 170p.il. 
acceptable) to remove surface dirt? What if it relates to the use to which the object was put? What if it has accumulated while the object was in use, but is incidental to the actual use? And what if the deposit is actually derived from the object itself?

Deposits relating to the original use of the object are usually known as 'ethnografical dirt' and may consist of food remains in vessels, wax or oil in lamps, traces of religious offerings on altars or images, or simply traces of animal secretions on horse harness for instance. A classic example is the blood stain on the shirt which president Lincoln was wearing when he was assassinated. In the past, all these stains and deposits would have been removed without question. Today, none of them would be."48

O politicamente correto, em sua origem - se é que podemos falar assim, - apresentou-se, exatamente, como uma filosofia legisladora, auto-limpante, sobre o mundo dos exageros. Era preciso podar arestas, evitar abusos, promover a sutileza de práticas e discursos. Mas ironicamente, pondera-se, o politicamente correto transformou-se em uma moral não de sutileza, mas de exagero. Todas as instâncias da vida social passaram a ser observadas e patrulhadas por uma ética ranheta e tola em seus excessos. Fumantes passaram a ser perseguidos, crianças estão sendo condenadas por "assediarem" sexualmente outras crianças e há indícios de que, brevemente, o chocolate será taxado como droga. Tudo em nome do bem, do que é certo e verdadeiro. Velhos não podem mais ser chamados de velhos, crianças transformaram-se em pré-adolescentes, e assim por diante. A noção ultrapassada da construção de uma sociedade em nome da fé e da moral, foi substituída pelo discurso ético, moralizante.

\footnotetext{
${ }^{48}$ Andrew Oddy, Restoration - Is it acceptable ? IN: RESTORATION. IS IT ACCEPTABLE ? BRITISH MUSEUM CONFERENCE, London, British Museum, p.3.
} 
Seguindo os novos tempos e a sensibilidade atual, portanto, a conservação de bens culturais não tardou em se fazer politicamente correta, elaborando um discurso e uma prática que alternam, o tempo todo, sutileza e exagero $^{49}$. Os exemplos são muitos e serão mais evidentes durante as discussões que serão feitas no capítulo seguinte. $\mathrm{O}$ discurso less is more, politicamente correto, portanto, passou a reger o trabalho dos museus formadores da opinião mundial, e portanto da maioria dos museus mundo afora, inclusive no Brasil e na Universidade de São Paulo. Inclusive no Museu Paulista.

\title{
2. $O$ especialismo: da restauração arte à conservação ciência.
}

\author{
“O homem de gosto cedeu o lugar ao \\ especialista. $" 50$
}

\footnotetext{
49 Várias das idéias relacionadas à sensibilidade atual que serão discutidas neste trabalho,nos foram sugeridas por Teixeira Coelho dentro da disciplina Cultura $e$ Sensibilidade, por ele ministrada na pós-graduação da ECA, em 1997.

${ }^{50}$ Esta afirmação encerra as considerações de Hegel sobre o gosto "Ter gosto é, pois, ter o sentimento, o sentido do belo; é uma apreensão que, sem sair do sentimento, passa por uma tal formatação que descobre o belo imediatamente, qualquer que seja e onde quer que esteja. A teoria das belas-artes e das ciências do belo destina-se a formar o gosto, $e$ tempo houve em que esteve muito em voga. mas o gosto é um modo sensível de apreender o belo, adotando, para com ele, uma atitude sensível. .....

Fala-se, hoje, menos do gosto porque, como meio de apreensão e juízo imediatos, ele se mostrou incapaz de nos levar muito longe e aprofundar o que quer que seja. Tudo exige um juízo em profundidade; o gosto, o sentimento, não perfura a superfície e contenta-se com reflexões abstratas. O gosto não vai além dos pormenores, a fim de que estes concordem com o sentimento, e repele a profundidade da impressão que o todo possa produzir. São os aspectos exteriores, secundários, acessórios, das coisas que importam ao gosto, e são-lhe suspeitos, porque repugnam ao seu amor pelas minudências, os grandes caracteres e as grandes paixões que o poeta nos descreve. Perante o gênio, o gosto recua e esvai-se.

Renunciou-se, pois, à tentativa de formar o gosto para adquirir um juízo fundado sobre a própria coisa e sobre seus aspectos. E assim se chegou a uma fase mais adiantada, a do especialismo.O homem de gosto cedeu o lugar ao especialista."
}

G.W.F. Hegel, ESTÉTICA: A IDÉIA E O IDEAL. SP: Abril Cultural, 1980 (Os pensadores). 
A idéia de que o mundo da arte foi preterido pelo mundo da ciência apresenta-se sempre como uma possibilidade instigante de análise. Em todas as áreas de atividade, em graus e cronologias diferenciadas, mencione-se, tal passagem pôde ser verificada: medicina, química, botânica, astronomia. A idéia também sempre sugeriu uma questão elementar: mudou o mundo, ou mudaram as coisas do mundo ?

O mundo politicamente correto, dentre outras coisas, trouxe aos anos 1990 a proposta de compartimentação total do sujeito, do assunto e do objeto. Se desde o pós-guerra verificara-se uma transformação paulatina nos perfís sociais e profissionais dos indivíduos assistimos nesta década ,com uma maior rapidez, triunfarem o especialismo e a visão de mundo ISO 9000. No contexto da conservação/restauração não aconteceu diferente; a frase de Hegel, se transportada para esse contexto específico, soa válida e pertinente. O restaurador-artista, homem de talento, cedeu lugar ao conservador-cientista. Certamente tal mudança no perfil do profissional não ocorreu rapidamente. A idéia corrente, hoje, é que ela teve início após a Segunda Guerra Mundial ${ }^{51}$.

Mais importante do que tentarmos datar tal transformação, todavia, seja pensarmos as idéias de passado e futuro que os diferentes perfís trazem associados. Nas últimas décadas o restaurador-artista, homem de talento ${ }^{52}$,

\footnotetext{
${ }^{51}$ Como referência a essa idéia vide Paul Philippot, Restoration from the Perspective of the Humanities. APUD: Nicholas Stanley Price et alli, op. cit., p. 217

${ }^{52}$ Uma distinção bastante interessante entre talento e gênio surge no romance de Allen Kurzweil, UMA CAIXA DE CURIOSIDADES, passado no século XVIII, durante a discussão de dois homens a respeito da natureza das qualidades de Claude Page, um habilidoso restaurador de objetos com mecanismo: “'Embora não deseje polemizar', ele polemizou, 'devo dizer que as qualidades que iguala são muito diferentes, meu caro amigo. Muito diferentes. Otalento qualifica alguém para um serviço específico. Trata-se de uma manifestação comum na capacidade externa de realização. O gênio é um dom raro, a posse dos poderes da invenção. Assim temos gênios na poesia e na pintura, mas talentos para falar e pintar.Os possuidores de talento na relojoaria nem sempre são gênios na mecânica." SP, Cia das Letras, 1993, p. 106.
} 
passou a ser associado - dentro do imaginário específico da área, - a um tempo passado e, certamente, ultrapassado. $\mathrm{O}$ artista muitas vezes associado à figura de Michelângelo, Rubens ou Aleijadinho - no contexto local -, deitado sobre andaimes sujos de tinta, passou a ser encarado como um amador, alguém não qualificado e inapto a dedicar-se ao trabalho de restauração ${ }^{53}$. Isto se deu primeiramente naquelas áreas chamadas "tradicionais" e só em um segundo momento foi estendida às demais especialidades. ${ }^{54}$

O conservador-cientista, por outro lado, é um especialista, um homem do futuro, de hoje, portanto. É curioso como estas noções se fundiram nesta última década: estamos vivendo um tempo presente que não é exatamente o presente- tal qual o entendíamos na década anterior, - mas um presente que já é futuro, aquele futuro que nosso imaginário social e afetivo fez construir sobre todas as coisas do mundo, aquilo que J.G. Ballard em vários de seus textos denomina como sense of the future ${ }^{55}$.

\footnotetext{
${ }^{53}$ No Brasil, principalmente nos anos 1980, várias polêmicas foram criadas, principalmente nas cidades históricas de Minas Gerais, quando artistas locais - ensinados por seus pais a manter e recuperar as pinturas das igrejas -, foram impedidos de trabalhar sob a alegação de não possuírem a especialização necessária.

${ }^{54}$ A principal a idéia a justificar os julgamentos das práticas profissionais, aqui, é aquela que especifica que o conservador não deve criar sobre o trabalho de outro.

${ }^{55}$ Dentre os vários textos do autor que discutem esta idéia, este, de 1982, é especialmente interessante:

"As THE YEAR 2000 approaches, releasing a rush of millenial hopes and fears, I take for granted that the future will once again play a dominant role in our lives. Sadly, at some point in the 1960s our sense of the future seemed to atrophy and die. Overpopulation and the threat of nuclear war, environmentalist concerns for our ravaged planet and unease at an increasingly wayward science together made everyone fearful of the future. Like passengers on a ship blown towards a rocky coast, we retreated to our cabins and drew the curtains over the portholes.

Yet I can remember when people throughout the world were intensely interested in the future, and convinced that it would change their lives for the better. In the years after the Second World War the future was the air that everyone breathed. Looking back, we can see that the blueprint of the world we inhabit today was then being drawntelevision and the consumer society, computers, jet travel and the newest wonder drugs transformed our lives and gave us a powerful sense of what the 20th century could do for us once we freed ourselves from war and economic depression. In many ways, we all
} 
A literatura de ficção traz alguns exemplos que ilustram bem essa mudança de perfil. Se, por exemplo, compararmos os personagens Claude Page, de A. Kurzweil em Uma Caixa de Curiosidades e Aoi Uë, de Salman Rushdie, em O Último Suspiro do Mouro, veremos que eles pouco tem em comum, embora tenham sido criados em data próxima ${ }^{56}$. O primeiro é um restaurador de mecanismos, do século XVIII, que aprendeu seu ofício com um velho Abade. O segundo, uma especialista japonesa da Fundação Miró, Barcelona, seqüestrada para Bombaim.

Claude Page é romântico, perfeccionista, um leitor compulsivo e crítico severo dos desenhos de Diderot na Encyclopédie ${ }^{57}$. Já Aoi Uë, é uma cientista, politicamente correta, cuja avaliação profissional fundamenta-se nos princípios éticos e científicos dos anos 1990: "Ao chegar ao Pequeno Alhambra, trazendo consigo seus instrumentos de trabalho, tal como ele lhe pedira com insistência, a restauradora foi levada para conhecer o 'Mouro' por ele pintado e as radiografias da pintura que havia por baixo da superficie; $e$ Vasco perguntou-lhe se seria possível exumar a pintura enterrada removendo a camada superficial. 'Seria perigoso, mas talvez possível, sim', disse ela, após realizar um exame preliminar. 'Mas certamente o senhor não vai querer destruir uma obra sua.' 'Pois foi para isso que a chamei até

became Americans, turning our backs on the past and confident that we could shape our world in any way we wished, dream any dream and see it come to life. For the first time the future was a better key to the present than was the past.

All this had ended by the 1970s, though a few romantics like myself still believe that our sense of the future remains intact, a submerged realm of hopes and dreams that lies below the surface of our minds, ready to wake again as one millenium closes and the next begins." J.G. Ballard MYTHS OF THE NEAR FUTURE. London, Vintage Books, 1994, Introdução.

56 Allen Kurzweil, UMA CAIXA DE CURIOSIDADES SP, Cia das Letras, 1993. Salman Rushdie, O ÚLTIMO SUSPIRO DO MOURO. SP, Cia das Letras, 1996. 
aqui', disse ele. Ela se recusou..." ${ }^{58}$. E a personagem só realiza o trabalho encomendado ao ser aprisionada e ameaçada de morte!

A construção da personagem de Salman Rushdie, ela própria, é intrigante. Sem dúvida, podem ser encontrados na India, hoje, vários profissionais de perfil semelhante ao apresentado pelo autor. E aqui vale a pena comentarmos um pouco a associação imediata, caricatural - que se tem neste fim de século XX, - de determinadas nacionalidades com esse ou aquele perfil de profissional. Poderíamos representar tal tendência em um quadro como este:

\begin{tabular}{|cc|}
\hline conservador-cientista & restaurador-artista \\
\hline Estados Unidos & Itália \\
\hline Inglaterra & Bélgica \\
\hline Canadá & França \\
\hline Austrália & Suíça \\
\hline Japão & países escandinavos \\
\hline & países leste-europeus \\
\hline & Egito \\
\hline & India \\
\hline & México \\
\hline & Peru \\
\hline
\end{tabular}

É evidente que um quadro dessa natureza pode ser analisado de diferentes formas. Nada se constrói nem se afirma no vazio. Se nos dias de hoje,

\footnotetext{
57 “ O editor da Encyclopédie descrevia, mas não fazia....Algo visual incomodava Claude, a qualidade das ilustrações. Claude disse que tinha objeções a elas porque não mostravam o suor, a dor, o medo da medida errada....” A. Kurweil, p. 98.

${ }^{58}$ S. Rushdie, op. cit. p. 436
} 
determinados países são associados a um determinado perfil, vários fatores com certeza, contribuíram para que isso ocorresse. Um dos fatores a serem considerados, sem dúvida, é o número de cursos universitários de especialização existentes nesses países e o capital investido na construção de grandes laboratórios analíticos que, não só garantiram o suporte científico necessário às pesquisas pretendidas, como também deram continuidade à especialização dos profissionais. Foi nesses países, igualmente, que surgiu a figura do conservator scientist, um analista de materiais e consultor científico: um conservador virtual que jamais entra em contato direto com um objeto, apenas com lâminas contendo amostras ${ }^{59}$.

Muitos podem considerar surpreendente que países como Itália, Bélgica e França, principalmente, sejam associados ainda hoje ao trabalho "artístico" a despeito das atividades e centros de pesquisa que desenvolvem. Ao mesmo tempo, é preciso destacar, existe o interesse dos países "científicos" em perpetuar essa situação caricatural, esse pretenso distanciamento de qualidade entre o trabalho de um grupo e outro. Por razões políticas, do mesmo modo, reforça-se deliberadamente, no contexto internacional, a "baixa qualidade" dos trabalhos desenvolvidos em países como Egito, India e México, países estes que há anos reivindicam no Tribunal de Haia o retorno de seus acervos ${ }^{60}$.

\footnotetext{
${ }^{59}$ Um bom exemplo do que discutimos pode ser encontrado no Smithsonian Institution nos Estados Unidos. A maioria dos seus museus possui, individualmente, laboratórios de conservação dotados de especialistas nas respectivas áreas de interesse do acervo que detêm. Apoiando esses laboratórios existe o CAL - Conservation Analythical Laboratory um complexo científico unificado com conservadores-cientistas especializados nos diversos materiais.

${ }^{60}$ Pudemos acompanhar em 1993, na Inglaterra, uma série de documentários na televisão que mostravam o "quão despreparados estavam os egípcios para salvaguardar seu patrimônio". Um deles, em especial, chegou a enfatizar a precariedade do trabalho de conservação realizado no Egito, focalizando um profissional quebrando um vaso na tentativa de restaurálo. Tais imagens, chocantes ao espectador comum, acompanhavam um discurso que alertava sobre os perigos que a devolução das coleções egípcias (em poder dos ingleses) traria ao patrimônio da humanidade. Segundo o editorial, caso os objetos - há décadas ambientados
} 
Podemos, afirmar, portanto, que as características de um ou outro perfil profissional acabam sendo enfatizadas conforme a situação convém. A postura inglesa é um bom exemplo dessa atitude "relativista". No contexto europeu os ingleses fazem questão de manter inabalada sua imagem de cientistas. Já em um ambiente euro-americano, apresentam-se orgulhosos de suas habilidades manuais e tradições artísticas ${ }^{61}$.

É mais fácil reconhecermos essa tendência de transformação no perfil do profissional deste fim de século XX, do que propriamente evidenciá-la. Mas talvez seja exatamente na atitude inglesa, acima mencionada, que possamos detectar o conteúdo principal, a atitude definidora de um perfil de conservador para este fim de milênio. Nem artesão, nem cientista: um profissional especializado, pesquisador, pós-graduado, que se apoia em toda a tecnologia e assessoria científica disponíveis para utilizar-se, então, de técnicas manuais tradicionais. "There seem to be an international agreement amongst conservation specialists that conservators/restorers should be trained at university or a comparable technical level. Much care should be taken to establish a sound equilibrium between practical training and theoretical knowledge. To compare again with the world of medicine: the physician who has no skill in his hands is no good. The physician and perfect craftsman who doesn't understand the chemistry of the human body or can not find the appendicitis is equally frightening". ${ }^{62}$.

\footnotetext{
ao clima europeu, - não fossem destruídos ao entrar em contato com o clima egípcio, fatalmente o seriam devido à falta de qualificação dos profissionais de museus daquele país !

61 "Os americanos estudam ciência e depois vêm para a Inglaterra aprender a usar as mãos!" Esta é uma frase bastante ouvida nos debates internacionais e meios profissionais ingleses.

${ }^{62}$ Agnes Gräfin Ballestrem, Lecture on Conservation Management IN: SEMINÁRIO DA ASSOCIAÇÃO BRASILEIRA DE CONSERVADORES E RESTAURADORES DE BENS
} 
No Brasil e outros países sul-americanos vemos conviverem os dois perfis profissionais que, peculiarmente, atuam com segmentos diferenciados ${ }^{63}$. Embora não possamos reduzir a realidade brasileira a uma mesma e única representação, o fato é que no país, hoje, formam-se profissionais para atender o mercado de arte e formam-se profissionais para atuar junto ao patrimônio público. Quase sempre os profissionais que atendem ao mercado de arte são associados e se fazem associar ao perfil do restaurador-artista, do profissional de talento, cujo aprendizado apenas reforçou um dom nato. E é este o imaginário da profissão que, sem dúvida, prevalece no Brasil. Bonito, chic, elegante, criativo, são comentários comuns associados à prática profissional no país.

Ao mesmo tempo os poucos cursos de formação existentes, bem como os profissionais que trabalham em instituições públicas e/ou museológicas, esforçam-se por transformar esse imaginário local- internacionalmente ultrapassado, -e firmar a imagem do conservador-cientista, do especialista completo, up-to-date. Este esforço pode ser verificado na simples construção de discursos e atitudes institucionais cientifizadas, como também em ofensivas bastante questionáveis como a desqualificação pública do outro perfil profissional, geralmente em nome de uma pretensa Ética. ${ }^{64}$

Contudo no caso do Brasil tal setorização de perfís profissionais não significa que os indivíduos a eles associados possuam qualquer coesão em suas práticas de trabalho. A falta de um pensamento e uma prática locais fizeram com

CULTURAIS - ABRACOR, 7, PETRÓPOLIS, 1994. Anais. Rio de Janeiro, ABRACOR, 1994, p. 17.

${ }^{63}$ Nossas afirmações relativas aos profissionais sul-americanos dizem respeito tão somente à área têxtil e, em especial à Argentina, Bolívia, Chile, Colômbia e Peru.

${ }^{64} \mathrm{O}$ esforço dos profissionais e instituições em reforçar seu perfil científico, nem sempre é acompanhado de uma prática coerente. No recente Survey on Scientific Research for the Conservation of Physical Heritage, realizado pelo ICCROM em 1997, dos vinte sete 
que idéias e metodologias de diferentes países, muitas vezes radicalmente divergentes, fossem transplantadas para cá e imediatamente absorvidas por aqueles profissionais mais jovens ou oriundos de regiões de menor contato com o estrangeiro. Estes, na maioria das vezes, não são informados sobre a origem daquilo que lhes é ensinado e tampouco da existência de outras abordagens igualmente válidas. Na Universidade de São Paulo não ocorreu diferente, como veremos no capítulo quarto: é o background do especialista e não a diretriz da instituição, o fator determinante na adoção deste ou daquele perfil profissional e de uma ou outra metodologia de trabalho ${ }^{65}$.

\section{A quimera sem rumo: o exagero nos museus}

\begin{abstract}
As grandes coleções são vastas, não completas. Incompletas: motivadas pelo desejo de completar. Sempre há mais um....Uma grande coleção é um concentrado material que continuamente estimula, superexcita. Não só porque sempre pode receber acréscimos, mas porque em si já é demais. A necessidade do colecionador é precisamente de excesso, exagero, profusão. ${ }^{66}$
\end{abstract}

O romance de Allen Kurzweil, já citado neste capítulo, tem como eixo central de sua narrativa uma caixa de curiosidades, um memento hominem do século XVIII, encontrado pelo narrador num leilão de antigüidades: uma caixa de madeira contendo um frasco de vidro, um manequim, um cogumelo,um botão,uma sineta, um relógio, um pintarroxo, uma pérola e um compartimento

profissionais/instituições convidados a participar, apenas o Museu Paulista/USP e a Biblioteca Nacional participaram.

${ }^{65}$ Vale a pena comentarmos que na recente reforma de carreiras da Universidade de São Paulo, as profissões de nível universitário, então denominadas Técnicas em.... - como na caso da conservação/restauração -, passaram a ser denominadas Especialistas em.....

${ }^{66}$ Susan Sontag, O AMANTE DO VULCÃO. São Paulo, Cia das Letras, 1993. p.78 
vazio. "Um memento hominem, (explica um velho senhor ao narrador) registra uma vida. Cada objeto na caixa indica um momento ou relacionamento decisivo na história pessoal de quem a montou. Os objetos escolhidos muitas vezes são comuns; os motivos para sua escolha, nunca..”

E prossegue o narrador ainda encantado com sua recente aquisição: " $O$ que havia de tão forte naqueles objetos protegidos? Talvez o fato de o meu mundo estar do lado de fora. Ou de algum mundo imaginário estar guardado ali dentro?...... Durante os seis anos seguintes pesquisei, restaurei, desvendei o mistério da vida de Claude Page......Por que fiz isso, não posso explicar adeqüadamente. Suponho que no fundo tenha sido o seguinte: vi a caixa e queria entendê-la. Este desejo de compreender transformou-se em obsessão no sentido clássico e satânico, significando o antecedente da possessão...... Eu não possuo a caixa, é a caixa que me possui. Para alguns, estes objetos podem não ter sentido. Para mim têm muito. Por que um botão, uma concha ou um frasco de vidro merecem tanta atenção? Para obter esta resposta, é preciso ter paciência para ler o resto. ${ }^{\circ 7}$

São inúmeras as associações que as imagens trazidas pelo texto acima possibilitam de imediato: história, memória, preservação, identidade, patrimônio, propriedade, pesquisa.... e também obsessão.... e exagero. Nossa intenção, neste tópico específico, será discutir a idéia de que estes dias encontram-se marcados por um crescente exagero que anda ,cada vez mais, se fazendo refletir e projetar nas atividades de preservação e, em especial, nos

\footnotetext{
${ }^{67}$ A. Kurzweil, op.cit. pp. 9-11.
} 
museus. E é claro que tal idéia surge relacionada com o politicamente correto e outros movimentos e tendências dos anos 1990, mencionadas anteriormente ${ }^{68}$.

Muito já se escreveu e argumentou sobre cada um dos termos acima grifados. Necessariamente todo texto que se proponha discutir o assunto museu parece ter por obrigação percorrer certos trajetos intelectuais clássicos, eles próprios já patrimonializados pelo pensamento dominante e, muitas vezes, involuntariamente transformados em clichés ${ }^{69}$. Nosso objetivo, aqui, entretanto, será apenas investir na discussão de um termo específico, não explorado, que consideramos uma tendência nas práticas e no pensamento museológicos atuais. A proposição, não sabemos se necessariamente nova, mas por certo incomum, poderá ser importante para as discussões que serão feitas no decorrer deste ensaio.

Abuso, excesso, sem naturalidade, hipérbole; assim se define, geralmente, a palavra exagero. Sua utilização requer, de imediato, que pensemos uma unidade, uma média do que quer que seja, comum a todos ou à maioria; que pensemos a existência de algum padrão desejável, de uma normalidade a ser

\footnotetext{
${ }^{68} \mathrm{O}$ historiador Edgard de Decca, em 1992, foi pouco compreendido ao introduzir uma discussão diferenciada sobre várias destas idéias. "Esta busca do mesmo no espelho do passado não é nada mais do que a manifestação do narcisismo contemporâneo, que tem imensas dificuldades de reconhecer as diferenças no tempo e no espaço e que, ao contrário, a história tem procurado fazer o inventário. Onde a memória persegue a identidade, a história se constrói como inventário das diferenças, numa tensão que envolve de forma permanente o indivíduo contemporâneo." Edgard de Decca, Memória e Cidadania IN: O DIREITO À MEMÓRIA.Patrimônio Histórico e Cidadania. São Paulo, Secretaria Municipal de Cultura, 1992. p. 135.

${ }^{69}$ Vale a pena mencionar aqui o comentário de Alain De Botton sobre os clichés, em texto recente: "The problem with clichés is not that they contain false ideas, but rather that they are superficial articulations of very good ones. The sun is often on fire at the sunset and the moon discreet, but if we keep saying this every time we encounter a sun or a moon, we will end believing that this is the last rather than the first word to be said on the subject. Clichés are detrimental in so far as they inspire us to believe that they adequately describe a situation while merely grazing its surface. And if this matters, it is because the way we speak is ultimately linked to the way we feel, because how we describe the world must at some level reflect how we first experience it."Alain De Botton, HOW PROUST CAN CHANGE YOUR LIFE. London, Macmillan Publishers, 1998, p.97.
} 
mantida ou buscada. Num primeiro momento tenderíamos a pensar o exagero como alguma coisa que destoa, que incomoda pelo excesso.

Este fim de milênio, entretanto, parece ter feito do excesso a sua regra. Apresenta-se hiperbólico, exagerado, com tudo e para tudo; estaríamos, acreditam alguns, vivendo um novo processo de barroquização de nossa vida social: economia, política, religião, propaganda, moda. $\mathrm{O}$ excesso estaria em toda a parte. A nossa sociedade ocidental contemporânea apresentar-se-ía como uma sociedade exagerada, aglutinadora de sensibilidades, atitudes e práticas igualmente exageradas. ${ }^{70}$

A sociedade exagerada, tudo leva a crer, organiza-se através de um ideário igualmente exagerado. Aparentemente poder e exagero sempre caminharam juntos, sempre foram prerrogativa daqueles que dominaram ${ }^{71}$. $\mathrm{O}$ mundo burguês, todavia, tratou de expandir os domínios do exagero: consumo, oferta, excesso, variedade, mercado, acumulação, lucro, mais-valia; o conteúdo

\footnotetext{
${ }^{70}$ Um dos defensores desta idéia é Michel Maffesoli, que em várias passagens de seu livro NO FUNDO DAS APARÊNCIAS, discute esta idéia de um novo momento barroco. " $O$ enfraquecimento dos limites, a instabilidade das estruturas, a "multiplicação de largos contrastes" que se pôde notar na arte é uma excelente definição da vida social em vias de barroquização. Ela justifica bem a heterogeneidade galopante, tendências contraditórias que, em todos os domínios, animam em profundidade nossas sociedades. É porque o mundo é aceito pelo que é, tal como é, que há pluralismo. A atitude voluntarista a saber, mudar o mundo, construir uma sociedade perfeita, por mais banal que seja, tinha tendência a reduzi-los (mundo e sociedade) ao que eles deviam ser. É aí que repousa o grande fantasma do uno. Por isso, desde que se outorga ao "mundo que esta aí" uma realidade ontológica, somos obrigados a reconhecer sua multidimensionalidade. É a partir dessa lógica que é preciso compreender o declínio do individualismo que se acelera atualmente. Ele é certamente a melhor expressão da pluralização. Quer se queira quer não, e de qualquer nome que o chamemos, o "neotribalismo" está aí, presente no conjunto dos modos de vida. Tudo isso se subsume num reencantamento com o mundo, de contornos ainda bem nebulosos (religiosidade, astrologia, culto do corpo, ligações diversas) mas cuja eficácia não é menos real." Michel Maffesoli, NO FUNDO DAS APARÊNCIAS, Petrópolis: Vozes, 1996 p. 221-222

${ }^{71}$ Essa idéia permite que pensemos tanto em momentos históricos mais recentes, como o período nazista, quanto em períodos bem anteriores, das cortes francesas ou inglesas dos séculos XVII e XVIII.
} 
moral do capitalismo parece, sem dúvida, ser fundado no exagero. Não erraríamos em dizer, assim, que ele sempre tenha estado presente em menor grau, embora nunca tendo sido, como hoje, o elemento qualificante, a idéiabase. E esta idéia-base-exagero, com certeza, surge associada ao pensamento politicamente correto $^{72}$. Aparentemente um contexto como esse acabou por gerar um gosto pelo exagero e, mesmo uma sensibilidade exagerada. Tudo, hoje, parece ser muito: muito grande, muito feio, muito cheio, muito chato. As experiências cotidianas, por certo, vêm sendo construídas sobre e com excessos de toda a natureza: de slogans televisivos a textos jornalísticos, da alimentação à literatura. Nosso juízo sobre o mundo e as coisas do mundo estariam, dessa forma, impregnados por um olhar hiperbólico, já introjetado em nosso juízo, a influenciar e condicionar, mesmo, o nosso agir e nossa reflexão sobre esse mesmo mundo.

O exagero, enquanto raiz estética desta década,produziu uma série de obras de cultura com qualidade. Kika, Pulp Fiction, Encaixotando Helena,

\footnotetext{
${ }^{72}$ Dentre os vários comentários que temos lido ultimamente sobre o exagero do mundo politicamente correto, destacamos este, da ensaísta inglesa Lynn Trust: " 'Fish have rights'. Of course I laughed out loud - rights to what? fair trial? freedom of expression? abortion on demand? - but then stopped, confused. I mean, perhaps 'Fish Have Rights" was a joke. Or maybe it was the name of a really famous pop group. Worse, perhaps it signified nothing at all, but had been written by an unreconstructed surrealist, to see whether the word 'fish' in peculiar contexts still made people feel vertiginous and paranoid. In which case, I reflected, the experiment appeared to be working.

But it's all true. 'Fish Have Rights' is the latest thing in the antibloodsports campaign, and the British angler is the object not only of moral opprobrium but of sabotage attack. Really.... Personally, I could never love a fish, It is something to do with their short memories. Call me anthropocentric, but I refuse to lavish affection on a creature that, every few seconds, can't remember where it's seen you before..... But what really astounds me in this 'Fish Have Rights' business is that any sane person, looking around at the world's current brutalities, would put angling at the top of their activist agenda. Presumably they watch the news from Bosnia with their mouths open and their eyes all glassy, making little occasional 'Pup!' noises with their lips." Lynne Truss, MAKING THE CAT LAUGH. Londres, Penguin Books, 1996
} 
Perdas e Danos e o desenho Rei Leão seriam alguns exemplos no cinema ${ }^{73}$. O Palácio da Lua e Música do Acaso de Paul Auster, Coração Tão Branco de Javier Marías e Fima de Amós Oz, na literatura ${ }^{74}$. Exagerado, de Cazuza; Mais Simples, de José Miguel Wisnik e Kátia Flávia, A Godiva do Irajá, na canção brasileira ${ }^{75}$. E do mesmo modo poderíamos buscar exemplos nas artes

\footnotetext{
${ }^{73}$ ATA-ME (1992) e KIKA (1994 ), de Pedro Almodóvar; PULP FICTION (1995), de Quentin Tarantino; ENCAIXOTANDO HELENA (1993), de Jennifer Lynch; e DAMAGE (1992) de Louis Malle. A coincidência, nas datas, parece ser indicativo de alguma coisa.
}

${ }^{74}$ Paul Auster, MOON PALACE. London, Faber \& Faber, 1989.

A MUSICA DO ACASO. SP, Bestseller, 1990; Javier Marías, CORAÇÃO TÃO BRANCO. SP, Martins Fontes, 1995. Amós Oz, FIMA. SP, Cia das Letras, 1996.

75 “amor da minha vidal daqui até a eternidadel nossos destinos foram traçados na maternidade; paixão cruel, desenfreadal te trago mil rosas roubadas/ prá desculpar minhas mentiras/ minhas mancadas; exagerado, jogado aos teus pés/ eu sou mesmo exagerado/ adoro um amor inventado; eu nunca mais vou respirar/ se você não me notar/ eu posso até morrer de fomel se você não me amar; e por você eu largo tudo/ vou mendigar, roubar, matarl até nas coisas mais banais/ prá mim é tudo ou nunca mais; exagerado, jogado aos teus pés/ eu sou mesmo exagerado/ adoro um amor inventado; $e$ por você eu largo tudo/ carreira, dinheiro, canudo/ até nas coisas mais banais/ prá mim é tudo ou nunca mais...."

Cazuza, Exagerado, década de 1980.

“é sobre-humano amar, você sabe muito bem/ é sobre-humano amar, sentir, doer, gozar, ser feliz/ vê que sou eu quem te diz/ não fique triste assim/é soberano e está em ti querer até muito mais/ a vida leva e traz/ a vida faz e refazl será que quer achar sua expressão mais simples/ mas deixa tudo e me chamal eu gosto de te ter/ como se já não fosse a coisa mais humana, esquecer/ é sobre-humano viver/ e como não seria/ sinto que fiz esta canção em parceria com vocêl a vida leva e traz / a vida faz e refazl será que quer achar sua expressão mais simples?" José Miguel Wisnik, Mais Simples,

(versão de Fernanda Abreu, 1997) “ Kátia Flávia/ É uma louraça Belzebu/Provocantel Uma louraça Lucifér/ Gostosona/ Uma louraça Satanás/ Gostosona e provocante/ Que só usa calcinhas comestíveis e calcinhas bélicas/ Dessas com armamentos bordados Calcinha de morango/ Calcinha Geladinhal Calcinha de rendinha Ex-miss Febem/ Encarnação do mundo cão / Casada com um figurão contravenção Ficou famosa por andar num cavalo branco/ Pelas noites suburbanas Toda nua, toda nua/ Toda nua, toda nua Matou o figurão/ Foi prá Copacabana/ Roubou uma joaninha/ E pelo rádio da polícia ela manda o seu recado/ Pelo rádio da polícia ela manda o seu recado Get out, get get out! Pelo rádio, pelo rádio, pelo rádio/ Pelo rádio da polícia ela manda o seu recado Alô polícia/ Eu tô usando/ Um Exocet/ Calcinha! Meu nome é Kátia Flávia/ Godiva do Irajál Me escondi aqui em Copa Alô, alô Polícial Polícia pode vir Polícia Belford Roxo, de Duque de Caxias/ Polícia Madureira, polícia Deodoro/ São Cristovão. 
plásticas e decorativas, nos brinquedos, na moda e por certo, nos museus. $\underline{O S}$ museus, como outras instituições contemporâneas, tornaram-se depositários e difusores do exagero fim-de-século.

Pensar o museu como instituição exagerada causa estranheza, num primeiro momento e talvez induza, num segundo, à uma associação imediata apenas com a arquitetura dos museus. Desde a inauguração do Musée Orsay na década de 1980, do Vasa em 1990 e outros tantos, até a recente abertura do Guggenheim Bilbao em 1997, vemos predominar nas edificações museológicas - sejam elas novas ou renovadas-, uma opção pela engenharia grandiosa, palaciana e monumental. A embalagem arquitetônica, todavia, é apenas um dos vetores de expressão do exagero: sem dúvida alguma o vetor que lhe é introdutório e o mais evidente ${ }^{76}$.

Desconhece-se qualquer pesquisa ou simples levantamento quantitativo que aponte com exatidão quantos museus existem no mundo, hoje, e quantos objetos estão sendo por eles preservados. E podemos afirmar com segurança que o número mais ousado que pudéssemos indicar, ainda assim ficaria muito aquém daquilo que de fato existe. Apenas o volume de acervo da Smithsonian Institution, nos Estados Unidos, já sugere a grandeza do número que obteríamos $^{77}$.

Bonsucesso, da Benfical Da Pavuna, da Tijuca, de Quintino, do Catete, Grajaúl Polícia, polícia, polícia/ Polícia 'pode vir/ Porque meu nome é Katia Flávia/ Godiva do Irajá...../

76 "Em geral os locais de armazenagem não precisam ser tão fantasiosos nem tão fortificados para serem seguros. Porém, se guardada num lugar que não dá sensação de segurança a coleção é uma constante fonte de ansiedade. Sobre o prazer paira o fantasma da perda." Susan Sontag, op.cit. p.206

77 " the Smithsonian Institution is the world's largest complex of museums and art galleries, with holdings in every area of human interest totaling more than 137 million objects and specimens". OFFICIAL GUIDE TO THE SMITHSONIAN. Washington, Smithsonian Insitution press, 1990 ed. p. 8 
No Brasil, igualmente, desconhecemos tal quantificação. O que temos disponível, apenas, são as informações apresentadas no GUIA DE MUSEUS BRASILEIROS $(1977)^{78}$. Os dados remetidos pelos museus que atenderam à solicitação da pesquisa, entretanto, são bastante incompletos e imprecisos quanto a quantificação e mesmo a classificação de seus acervos. As quantidades informadas encontram-se expressas das mais variadas formas: toneladas, metros lineares, volumes, lotes, caixas, coleções, fundos de arquivo, aquários...... . De qualquer modo, os números disponíveis são suficientes- dentro do contexto desta discussão- para ilustrar nosso argumento. A partir dos dados constantes no Guia, nos foi possível construir o quadro a seguir ${ }^{79}$ :

\begin{tabular}{|cccr|}
\hline região & $\begin{array}{c}\text { museus } \\
\text { cadastrados }\end{array}$ & $\begin{array}{c}\text { coleções } \\
\text { quantificadas }\end{array}$ & unidades de acervo \\
\hline AC & 01 & 1 & 271 \\
\hline AL & 10 & 7 & 14.364 \\
\hline AP & 03 & 1 & 746 \\
\hline AM & 11 & 11 & 11.291 .244 \\
\hline BA & 32 & 23 & 76.650 \\
\hline CE & 28 & 22 & 163.846 \\
\hline D.F. & 16 & 7 & 1.658 .725 \\
\hline ES & 08 & 5 & 20.613 \\
\hline GO & 13 & 11 & 145.665 \\
\hline MA & 03 & 3 & 5.354 \\
\hline MT & 06 & 4 & 21.253 \\
\hline MS & 02 & 2 & 23.660 \\
\hline MG & 135 & 64 & 491.934 \\
\hline PA & 11 & 7 & 1.472 .453 \\
\hline PB & 09 & 7 & 71.715 \\
\hline PR & 66 & 42 & 1.083 .108 \\
\hline
\end{tabular}

78 GUIA DE MUSEUS BRASILEIROS. São Paulo, Pró-reitoria de Cultura e Extensão Universitária/Comissão de Patrimônio Cultural, Universidade de São Paulo, 1997, 354 p. , idealizado e coordenado por Maria Christina Barbosa de Almeida.

${ }^{79}$ Note-se que não foram quantificados os números relativos aos materiais bibliográficos. 


\begin{tabular}{|crrr|}
\hline PE & 26 & 18 & 46.822 \\
\hline PI & 13 & 3 & 1.230 \\
\hline RJ & 59 & 41 & 2.846 .483 \\
\hline RN & 04 & 1 & 375 \\
\hline RS & 72 & 51 & 1.267 .558 \\
\hline RO & 04 & 0 & - \\
\hline RR & 01 & 1 & 1.320 \\
\hline SC & 39 & 30 & 160.412 \\
\hline SP & 176 & 107 & 13.966 .460 \\
\hline SE & 08 & 5 & 3.303 \\
Totais: & $\mathbf{7 5 6}$ & $\mathbf{4 7 4}$ & $\mathbf{3 4 . 8 3 5 . 5 6 4}$ \\
\hline
\end{tabular}

Antes de qualquer consideração sobre os números deste quadro, que reafirmamos ser apenas ilustrativo, é preciso que consideremos os seguintes pontos:

1. daquele montante não constam os Arquivos, Institutos e Bibliotecas de todo o país. Basta lembrarmos o Arquivo e a Biblioteca Nacionais, no Rio de Janeiro e o Instituto de Estudos Brasileiros da USP, por exemplo, para deduzirmos o volume de acervos não quantificados;

2. igualmente não constam, no GUIA, os acervos vivos: zoológicos, hortos, etc;

3. os números ali expressos correspondem apenas a uma parte das instituições cadastradas que, por sua vez, são uma parcela - ainda que significativa- da totalidade dos museus existentes no país.

Vejamos os números obtidos: menos de 500 instituições brasileiras dedicam-se a preservação de 34 milhões de unidades de acervo. Se nos detivermos na tradução de tais números e hipotéticamente calcularmos as relações custo/tempo/benefício, poderemos projetar alguns números bastante esclarecedores.

1. custo: se supusermos que cada unidade de acervo gere um custo de $\mathrm{R} \$ 2,00$ reais/ano (incluindo despesas com pessoal, materiais, infra-estrutura) chegaremos à cifra de $\underline{\mathrm{R} \$ 68.000 .000,00 / \text { ano }}\left(\right.$ sessenta e oito milhões de reais) ${ }^{80}$;

\footnotetext{
${ }^{80}$ Ao leitor do futuro: quando este ensaio foi escrito $\mathrm{R} \$ 1$ equivalia a aproximadamente $\mathrm{U} \$ 1$.
} 
2. curadoria: se supusermos que cada instituição conte com uma equipe de 20 funcionários, num total de 8.000 (400 museus x 20), teremos cada um deles responsável pela curadoria- pesquisa, conservação, difusão- de $\underline{4.250 \text { unidades }}$ $\underline{\text { de acervo; }}$

3. exposição: se supusermos que cada museu tenha condições de expor 1.000 unidades de acervo por ano, concluiremos que as instituições levarão 85 anos para expor suas coleções $\{[400$ museus x 1.000 unidades/ano $=400.000$ unidades/ano] 34.000.000 de unidades : 400.000 unidades/ano $=85$ anos $\}$.

Sabemos que as relações apontadas acima são generosas e que as quantificações apresentadas estão super-estimadas. A maioria das instituições brasileiras, ou mesmo a sua totalidade, não têm condições de cumprir nenhuma das suposições acima, seja quanto ao número de funcionários disponíveis seja em relação às atividades de curadoria.

Uma simples quantificação como esta certamente causa surpresa e alguma perplexidade. E aqui a questão não se limita mais aos acervos brasileiros, mas a tudo que está sendo preservado em toda a parte. Afinal por quê o fazemos se sabemos que não teremos tempo de estudar, conservar e exibir tudo isso ${ }^{81}$

Aparentemente tudo está sendo preservado, de objetos de chocolate a computadores e aviões; de sons e ruídos a corações dissecados e perfumes. Os campos de domínio e interesse na formação de coleções das diferentes modalidades de museus, se integrados, parecem cobrir todas as manifestações

\footnotetext{
${ }^{81}$ Mais uma vez Susan Sontag colabora com a nossa discussão: “A morte dos objetos pode desencadear uma dor ainda mais desnorteante do que a morte de uma pessoa amada. As pessoas têm de morrer, por mais difícil que seja manter isto em mente. Quer se viva com tediosa prudência, quer se corteje a morte... o fim é o mesmo, inevitável. Já os objetos.... uma das razões pelas quais nos apegamos a eles, os colecionamos, é que não é inevitável que eles algum dia sejam extraídos do mundo.” Susan Sontag, op. cit. p. 258
} 
do planeta, sem excessão ${ }^{82}$. E essa totalidade, por si só, já parece indicar uma contradição de origem: quando tudo é patrimônio, nada é patrimônio !Tudo indica que perdemos, enquanto culturas, o bom senso, a medida e a justificativa da preservação. Uma quimera sem rumo: assim vem se caracterizando nossa atitude em relação à salvaguarda de bens culturais neste final de milênio. Algo irrealizável, fantasioso e "fora de controle" 83 .

A questão do exagero nos museus, todavia, não se limita à quantidade de acervos preservados. Praticamente todas as suas atividades estão imersas nessa mesma atitude e pensamento exagerados.

No campo específico da conservação, como mencionado no primeriro capítulo, o exagero está em toda a parte. A conservação tornou-se um dos principais modos de propagandear a museologia exagerada. Vitrines que deterioram $^{84}$, iluminação com fibra ótica ${ }^{85}$, sistemas de armazenagem futuristas ${ }^{86}$ :

\footnotetext{
${ }^{82}$ Uma outra pesquisa interessante, sem dúvida, seria descobrir em meio a todos esses campos algum que, consensualmente, se acreditasse_não ser objeto de interesse e preservação por um museu qualquer.

${ }^{83}$ A escolha do termo quimera foi proposital. Nossa intenção foi fazer referência às idéias de fantasia e mitologia (o monstro com cabeça de leão, corpo de cabra e cauda de dragão) e também remeter à Chimera d'Arezzo, escultura italiana, objeto de um belíssimo projeto científico de intervenção do cientista Marco Ferretti, com quem discutimos muitas das questões deste ensaio e outras tantas mais. LA CHIMERA D'AREZZO. Firenze: Ministero per I beni culturali e ambientali.Soprintendenza archeologica e ambientali della Toscana/ ENEA- Ente per le nuove tecnologie e l'ambiente, 1992,139p.il.

${ }^{84}$ Há alguns anos a divisão científica do Victoria \& Albert Museum vem se dedicando a construir um tipo de vitrine feita com materiais que deteriorem em proporção superior aos objetos que protegem e cuja deterioração possa ser visualmente constatada. A idéia é fazer com que a vitrine reaja à eventuais condições de exposição inadeqüadas antes que o objeto seja prejudicado.

${ }^{85}$ A iluminação com fibra ótica é considerada, hoje, a melhor opção do ponto de vista da conservação de objetos muito sensíveis à luz, como os têxteis. Sua utilização, além de facilitar o direcionamento dos focos de iluminamento, pode garantir uma luminosidade praticamente isenta de radiações ultravioleta e infravermelha. Seu custo, entretanto, é bastante elevado. Sobre suas propriedades e aplicações vide: Larry V. Bowers, Lighting for Preservation - Fiber Optics in Museum Exhibits. IN: FABRIC OF AN EXHIBITION: AN INTERDISCIPLINARY APPROACH. Op.cit. p. 105-110. Na mesma publicação encontra-se um estudo importante de Stefan Michalski, do Canadian Conservation Institute, no qual o
} 
nada, neste campo, parece ter limites. Mais uma vez, perdeu-se a idéia inicial, o para quê. O para quê da conservação e mesmo seus extremos de sofisticação fizeram e fazem sentido em determinados contextos. Objetos milenares, quando importantes, evidentemente necessitam de atenção especial se quisermos garantir sua preservação por quem sabe outro milênio mais. Tais situações, contudo, não devem exceder a $10 \%$ de qualquer montante imaginado. O restante, na verdade, é fruto do exagero, do politicamente correto .E estranhamente seja no Brasil seja no estrangeiro, pouco se discute sobre o assunto, isto para não afirmarmos que inexistem reflexões sobre a questão. Tal qual o coelho de Lewis Carrol, que só existe para estar atrasado, ou as formigas argentinas de Italo Calvino ${ }^{87}$, os museus só admitem existir para acumular e conservar o que acumulam, num ciclo viciado e sem fim; transformaram-se em baús dos tesouros nacionais e depósitos de toda e qualquer coisa. Sua importância parece inquestionável e suas práticas acima do bem e do mal. E ninguém, tampouco a Universidade, parece preocupado em enxergar tanto exagero, contido tão somente pela insuficiência de recursos.

Arquitetura, exposições, projetos sofisticadíssimos de conservação parecem aproximar cada dia mais o museu do supermercado, do shopping center e do parque de diversões. A Themed Entertainment (empresas Disney), por exemplo, coleta, pesquisa, conserva e divulga acervos históricos. Recentemente, inclusive, a conservação de suas coleções, foi tema de estudo apresentado em

pesquisador questiona os antigos índices de iluminamento recomendados pela bibliografia das últimas décadas: The Lighting Decision, p. 97-104.

${ }^{86}$ A sofisticação dos sistemas de armazenagem nos grandes museus estrangeiros é difícil de comentar: sistemas eletrônicos giratórios para guarda de tapeçarias; câmaras frias para guarda de objetos em pele, couro, chocolate, etc; mobiliário específico para cada objeto particular etc.

${ }^{87}$ referimo-nos ao coelho de ALICE NO PAÍS DAS MARAVILHAS e ao conto As FormigasArgentinas, de Italo Calvino,em seu livro OS AMORES DIFÍCEIS. 
congresso científico $^{88}$. O que diferencia uma organização como esta, portanto, de um museu qualquer? As respostas-cliché parecem insuficientes.

A imagem da caixa de curiosidades, infelizmente, parece estar perdendo força. Na sociedade exagerada o memento hominem foi substituído pelo Jack in the Box.

\section{Introduzindo uma necessidade - o tecido como documento.}

Sei o que você está pensando, disse Tweedledum; mas não é. Muito pelo contrário, continuou Tweedledee, se fosse, poderia ser; e se assim o fosse, seria; mas como não é, não será. Assim é a lógica. ${ }^{89}$

Tecido também é documento! Tal frase pôde ser escutada repetidas vezes como chamada de diferentes telejornais e programas de rádio veiculados

\footnotetext{
88 "Themed Entertainment, an industry unique to the late 20th century, is a broad umbrella term covering many seemingly unrelated enterprises. There are the obvious themed amusement parks, such as Disneyland or Busch Gardens, but the Themed Entertainment industry actually covers a vast range of business. A "themed" venue can be as simple as a neighbourhood Chinese restaurant where the dining room ambiance is created by the use of traditional Chinese art, music and design. It can be as complicated and temporary as the 1996 Summer Olympics in Atlanta, Georgia. It includes restaurants such as Planet Hollywood, and the Hard Rock Cafe, gaming resorts like Ceasar's Palace in Las Vegas, NV, and retail stores like Niketown on 57th St. in New York City. It is the new, popular, cultural museums such as the Rock and Roll Hall of Fame and Museum in Cleveland, Ohio or the Experience Music project scheduled to open in Seattle, Washington in 1999. It even can be an entire town such as Branson, Missouri. Whether a huge corporation or a small local establishment, these businesses provide the playgrounds for millions and millions of people every year. They give us entertainment, education, diversion and fun in a theatrical, themed setting whether it is Golden Years of Hollywood, ancient Rome or a 1950s bebop cafe. In the realm of the arts, Themed Entertainment is the wave of the 21 st century.... Original photographs, posters, costumes and other cultural materials are finding their way onto the walls and into display cases of a variety of these venues."

Cara Varnell, 'Let Me Edu-tain You,' Historic Artifacts and the World of Themed Entertainment. IN: FABRIC OF AN EXHIBITION: AN INTERDISCIPLINARY APPROACH. Op.cit. p. 163.

${ }^{89}$ Tweedledum and Tweedledee, Alice's Adventures in Wonderland IN THE COMPLETE ILLUSTRATED WORKS OF LEWIS CARROLL. London: Chancellor Press, 1984, p. 156.
} 
na cidade de São Paulo, em 1997, além de resultar na produção de uma matéria sobre o trabalho de Conservação de Têxteis no Museu Paulista/USP para o programa VITRINE da TV Cultura de São Paulo, de veiculação nacional ${ }^{90}$.

Estes acontecimentos inusitados, somados à uma publicação da Universidade de São Paulo ${ }^{91}$, à uma palestra realizada em Londres ${ }^{92}$, a um convite do ICCROM para integrar uma pesquisa internacional ${ }^{93}$ e à oficialização de um Setor de Conservação de Têxteis na $\mathrm{USP}^{94}$ surgiam como indicativos de que uma idéia - nascida anos atrás-, havia vingado e atingido solidez e amplitude inesperadas.

No acaso e na fortuna ${ }^{95}$ - a despeito do que sociedade e comunidade universitária esperem ou idealizem sobre a Universidade, - é onde quase sempre encontramos a origem de projetos individuais/institucionais bem sucedidos.

\footnotetext{
${ }^{90} \mathrm{~A}$ frase mencionada abriu os telejornais das TVs Bandeirantes, Record e Canal 21 entre os dias 20 e 22 de agosto de 1997; da Rádio Eldorado em 25/ago/97 e 13/set/97. Constou ainda de reportagens dos jornais: O Estado de S.Paulo, 11/maio/97;- Diário Popular, 16/maio/97; A Gazeta, 3/agosto/97; Diário Popular, 21/8/97; O Estado de São Paulo, 30/set/97; O Estado de São Paulo, 5/out/97. O programa VITRINE foi veiculado em 01 e 02 de novembro do mesmo ano.

${ }^{91}$ CONSERVAÇÃO E RESTAURO I. Recomendações e projetos em andamento na Universidade de São Paulo.SP, Pró-Reitoria de Cultura e Extensão Universitária - Comissão de Patrimônio Cultural, 1996.

92 “Conservação de Têxteis no Museu Paulista da USP, São Paulo, Brasil". The Textile Conservation Centre - Courtauld Institute of Arts - University of London - dia 10 de fevereiro de 1997, às 13:30.

${ }^{93}$ Survey on Scientific Research for the Conservation of Physical Heritage.

${ }^{94}$ O Regimento do Museu Paulista da USP, aprovado em 1997, criou oficialmente o Setor de Conservação de Têxteis.

${ }^{95}$ Fortuna aqui entendida como boa sorte, ventura, destino. Renato Janine Ribeiro é autor de um ensaio sobre esse tema em seu melhor livro A ÚLTIMA RAZÃO DOS REIS. SP, Cia das Letras, 1993.

Walter Benjamin, em seu ensaio Destino e Caráter, discute a idéia do acaso e do significado da expressão “ninguém escapa ao seu destino”. Vide: Olgária Matos, Memória e História em Walter Benjamin IN: O DIREITO À MEMÓRIA. Patrimônio Histórico e Cidadania. São Paulo, Secretaria Municipal de Cultura, 1991, pp.151-156.
} 
Conosco, não foi diferente. $\underline{\text { A idéia de trabalhar com têxteis foi decorrente de }}$ um incidente-desafiador: um quadro contendo um lenço comemorativo da Guerra do Paraguai, exposto por uma dezena de anos, caiu, teve sua moldura quebrada e nos foi encaminhado para providências. A falta de conhecimento sobre os materiais, a inexistência de bibliografia específica e de especialistas no país fizeram todo o resto ${ }^{96}$.

Iniciar um trabalho de pesquisa em museus, na área de conservação e no Brasil não é fácil. Quando se trata de uma atividade praticamente desconhecida e inexistente no país, a perspectiva pode ser desanimadora. Todo o conhecimento e experiências adquiridas na Inglaterra, país cuja organização social e política na modernidade se fez a partir da industria têxtil ${ }^{97}$, parecia esvaziado e sem sentido em nosso contexto específico: paulistano, museológico e universitário. A idéia do tecido como suporte de informação e criação, patrimônio e/ou documento causava estranheza e parecia referente a uma outra realidade, associada, quase sempre, apenas às rendas e redes nordestinas, mais ou menos confinadas em museus de "folclore ou cultura popular". E isso parecia tudo!

Nos países onde há tradição na preservação de têxteis, eles geralmente se encontram divididos em três grandes grupos: têxteis arqueológicos, têxteis etnográficos e têxteis históricos. Tal divisão, geralmente, obedece mais às tipologias dos museus e instituições que os abrigam do que propriamente a uma classificação conceitual coerente. Mas entre nós, todavia, sequer se equacionavam os têxteis como tipologia de acervo, mesmo eles sendo tantos e

\footnotetext{
${ }^{96} \mathrm{Um}$ breve histórico das atividades pode ser encontrado no texto CONSERVAÇÃO E RESTAURO I, op. cit., pp. 83-89.

${ }^{97}$ Apenas como referência desta afirmação ver Olive Howarth (ed) TEXTILE VOICES: Mill life this century. Bradford: Bradford Libraries \& Information Service/Heritage Unit, 1989. 84p.il.
} 
tão numerosos ${ }^{98}$. Aqui cabe, portanto, já defini-los: o termo têxtil, bastante amplo, abrange todos os tecidos- planos ou não - produzidos em determinado momento histórico e toda a enorme diversidade de objetos produzidos a partir desses tecidos. Cortinas, toalhas, indumentárias, tapetes, bandeiras, ursos de pelúcia e, igualmente, quando contenham algum elemento tecido, leques, bonecas, objetos de transporte como liteiras, cadeirinhas e carruagens, sapatos, gravuras, jornais, pinturas - e até múmias. Ou seja: é considerado acervo têxtil todo e qualquer objeto produzido parcial ou totalmente em tecido.

Apesar de numerosos em muitos museus, como no Museu Paulista, os têxteis sempre foram uma categoria "menor" de acervo. Tal situação, presente nos museus históricos, nos museus artísticos e nos museus etnográficos, pode ter sua explicação na valoração atribuída aos têxteis pelo mercado de arte, como já mencionamos no primeiro capítulo. Esta subvaloração dominante, por um lado, somada à falta de conhecimento sobre os materiais, de outro, fez com que historicamente as coleções têxteis sempre tivessem sido abordadas de forma equivocada. Esta era a situação em 1994, quando se iniciaram os trabalhos e a introdução de um ideário e de uma prática totalmente alienígenas.

Transmitir uma experiência individual a outros, tal qual comentar as emoções e cores de um sonho, quase sempre é motivo de frustração para uma das partes e de indiferença para as outras. Além dessa dificuldade natural, havia o temor justificado de que a nova iniciativa de trabalho caísse rapidamente no esquecimento, ou fosse inviabilizada por qualquer motivo, como acaba acontecendo com a maioria dos projetos no Brasil. A única estratégia possível, então, era "fazer barulho", mostrar o que se pretendia, dando materialidade às

\footnotetext{
${ }^{98} \mathrm{O}$ fato de nossa cultura tradicionalmente não valorizar os têxteis como objetos detentores de "valor", é, aliás, outro tema que mereceria ser estudado à parte.
} 
idéias e as transformando em fato $^{99}$. Assim se seguiram, concomitantemente, uma série grande de atividades: organização de um atelier de trabalho exclusivo no museu, intervenção sobre objetos da coleção, aquisição de equipamentos e materiais, elaboração de apostilas, cursos introdutórios, palestras de divulgação, tradução de textos, aquisição de bibliografia, assessoria a outras instituições e orientação de estagiários $^{100}$.

Num discurso radical, novo e cientifizante- com as devidas proporções, foram transplantados para o contexto local, tal e qual, toda a experiência e ideário absorvidos na Inglaterra. Não havia dúvidas em relação a nada do que era feito. Afinal tudo que se desenvolvia aqui já era consenso no estrangeiro e estava afinado com o que se fazia de melhor e mais científico. Aquilo que faltava, que não havia, era conjuntural, temporário e aos poucos seria resolvido $^{101}$.

As mudanças que ocorriam internamente no Museu Paulista acabaram por fornecer ao projeto, por sua vez, o lastro necessário ao seu desenvolvimento. O trabalho teve início e depois se implantou dentro de um momento institucional bastante específico: uma nova direção trouxera um plano diretor que redefinia as linhas de pesquisa e campos de atuação do museu, colocando-se frente à Universidade com um discurso museológico e um perfil bastante diversos dos praticados anteriormente. Harvard da Colina: assim, ironicamente, passou a ser

\footnotetext{
${ }^{99}$ com referência, aqui, à idéia todo fato social é coisa, de E. Durkheim em AS REGRAS DO MÉTODO SOCIOLÓGICO:

${ }^{100}$ Dentre as muitas atividades desenvolvidas no The Textile Conservation Centre, onde se deu nossa especialização, constava o planejamento de uma estratégia de ação a ser desenvolvida no Museu Paulista quando regressássemos. Este planejamento, como a orientação e avaliação semanais de nossas atividades foi executado sob a supervisão direta de Janey Cronyn, Head of Sciences and Research daquele centro. Seu rigor e lucidez foram fundamentais ao sucesso das atividades pretendidas, mas sobretudo ao nosso entendimento do que significa ser profissional.
} 
conhecido o Museu Paulista dentro da própria Universidade ${ }^{102}$. O contexto, portanto, favorecia novas idéias e projetos que reforçassem aquela nova imagem institucional.

Naquele momento nenhuma das questões discutidas anteriormente neste capítulo, o politicamente correto, o exagero, o less is more se colocavam. Era preciso criar "novos" procedimentos e atitudes dentro e fora do museu, cientifizar. O perfil profissional adotado só poderia ser aquele do conservadorcientista. E neste ponto, sem dúvida, o aparato universitário foi fundamental à veiculação do que se pretendia.

Era necessário dar credibilidade interna e externa às novas atividades de conservação. Afinal, o que diferenciava esta atividade dos serviços comerciais de lavanderia , tinturaria e corte-costura ? Qual a diferença entre um têxtil restaurado e uma falsificação? Estas e outras perguntas precisavam ser respondidas com exemplos, era preciso mostrar ${ }^{103}$.

A construção de um novo discurso começou pela imposição, até hoje necessária, da expressão conservação de têxteis ao invés de restauração de têxteis: a diferenciação dos termos - já definidos no primeiro capítulo- era fundamental à consolidação de um novo modo di fare e à propaganda desta atividade como algo inusitado. $\mathrm{O}$ atelier de trabalho, embora provisório, impunha novos procedimentos àqueles que o visitavam: por toda a sala, etiquetas solicitavam que os objetos não fossem tocados e um informe, já na porta,

\footnotetext{
${ }^{101}$ Esta idéia de que no Brasil falta isso, falta aquilo, não estaria , no fundo, ligada ao tamanho do nosso território, ao vazio geográfico?

${ }^{102}$ Em 1989 assumiu como diretor o Prof. Dr. Ulpiano T. Bezerra de Meneses que fez do Museu do Ipiranga, o Museu Paulista da Universidade de São Paulo. O trabalho de conservação de têxteis - assim como boa parte de tudo de bom que tenhamos feito desde nossa primeira discussão, em 1978, - talvez não se tivesse iniciado sem sua valiosa orientação.
} 
informava que canetas não eram benvindas ${ }^{104}$. Seguiu-se muito trabalho, mas a associação atividade nova- Inglaterra -ciência-Universidade de São Paulo, mostrou-se de fácil penetração tanto no meio específico quanto na imprensa ${ }^{105}$.

A "propaganda" da nova atividade através de mostras teoricamente temporárias, aliada à imagem de um "novo museu" trouxeram um retorno imediato. E esse retorno, uma consequência específica: o aumento da coleção de objetos têxteis. Tipologias antes pouco numerosas, como chapéus civis, bolsas, e luvas, por exemplo, mas também tecidos decorativos, acessórios e outros grupos, começaram a aumentar muito. Um acervo que antes era dominado por coleções de bandeiras, fardas e indumentária de "celebridades e heróis", como Santos Dumont e a Marquesa de Santos, passou a apresentar como tema dominante- num curto espaço de tempo -, objetos ligados ao cotidiano, ao trabalho, e à casa paulistas.

Outra decorrência da "novidade" foi o interesse que as atividades geraram em outras instituições do estado e do país. Os cursos introdutórios e workshops realizados em eventos organizados fora da Universidade atraíram profissionais e instituições de outras localidades do Brasil e América Latina, em

103 Tal dificuldade de compreensão aumentou, inicialmente, quando foram adquiridos equipamentos domésticos como máquinas de costura, de lavar e secar, ferro elétrico, etc, necessários para preparar os tecidos utilizados em embalagens e suportes.

${ }^{104}$ Aqui cabem dois esclarecimentos: o primeiro sobre o aviso de não tocar, colocado sobre os objetos em tratamento. Curiosamente o comportamento das pessoas em geral, em relação a um objeto têxtil, é bastante diferenciado. Não é comum, mesmo internamente nos museus, encontrarmos pessoas passando as mãos sobre uma tela ou outro objeto qualquer. Já os

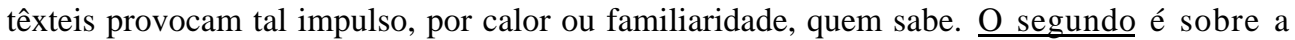
proibição de canetas no atelier. Exagerado ou não, tal princípio baseia-se no fato de que, dificilmente, uma mancha ou ponto causados por tinta de caneta, principalmente esferográfica, poderá ser removido sem prejuízo do tecido.

${ }^{105}$ Um exemplo curioso da divulgação dessa nova atitude pode ser encontrado no uso de uma etiqueta-aviso. Nos ateliers e laboratórios no exterior é costume encontrarmos junto aos objetos que estão sendo trabalhados, uma etiqueta com os dizeres DO NOT TOUCH. CONSERVATION IN PROGRESS. No atelier de têxteis ela foi adotada como NÃO TOQUE, 
busca de informações, bibliografia específica e treinamento. Os pedidos alheios de parecer técnico tornaram-se comuns e, as atividades ainda tão recentes, com muito pouca experiência e nenhuma tradição local passaram a ser referência.

Se de um lado tal situação garantia o retorno desejado, assegurando a continuidade dos trabalhos, de outro incomodava pela desproporção entre imagem construída e conteúdo real. Ao nome Universidade de São Paulo, como sabemos, costuma vir associada a idéia de excelência. Todavia, diferentemente do que ocorre em tantas outras especialidades, sabe-se que esta qualificação não se aplica nem à área de museologia nem à de conservação/restauração entre nós. Infelizmente, estamos ainda muito aquém daquilo que se produz de melhor no país, mesmo considerando-se que este melhor é quase sempre muito fraco e muito pouco.

Esta discussão, entretanto, era uma questão interna e não importava àqueles que se descobriam interessados numa nova área de investigação. A necessidade havia sido criada: a idéia de que temos um patrimônio têxtil a ser preservado estava introduzida. Os museus, ao reconhecerem os têxteis como uma tipologia igualmente "importante" de acervo, davam-se conta, também, de seu sofrível estado de conservação, e de seu despreparo para conduzir o problema. Museus e instituições, as mais diversas, começaram a se apresentar como depositárias de coleções têxteis. O que antes parecia não existir, surgia, repentinamente, muito grande e bastante difícil de ser enfrentado. Mas a perspectiva de trabalho, embora insuflada, continuava positiva.

Entretanto outras questões começavam a surgir. Como apenas um especialista poderia encaminhar todas as solicitações e todo o interesse despertado, mantendo-se fiel a um padrão e critérios alienígenas ? A resposta era evidente: novos procedimentos, emergenciais ou não, precisavam ser adotados, 
prioridades precisavam ser estabelecidas e necessidades relativizadas. A própria idéia de problema precisava ser reconsiderada, era preciso simplificar e identificar o importante ${ }^{106}$.

Nesse instante, acreditamos, teve início um novo momento de trabalho. Rompia-se, assim, o transplante automático de ideário e prática estrangeiros e tinha origem, um trabalho socialmente mais coeso e pertinente. $\mathrm{O}$ discurso científico, exagerado e politicamente correto começava a ser questionado em trabalhos externos ao Museu Paulista e à Universidade de São Paulo ${ }^{107}$. Internamente, como veremos no capítulo seguinte, as mudanças ainda não se fizeram refletir.

instituições, inclusive em algumas onde inexistem conservadores e ateliers de conservação ! 106 A verdade é que havia problemas a resolver e profissionais a serem minimamente treinados. As situações ideais - mandar outros profissionais ao estrangeiro e estruturar um curso no Brasil com profissionais de outros países - levariam, a curto prazo, à paralisação das atividades do Museu Paulista. Hoje, apesar de contarmos com outros dois especialistas no Rio de Janeiro, a dificuldade persiste já que aqueles profissionais não têm por objetivo a pesquisa e a difusão de suas práticas .

107 A própria mudança no conteúdo de nosso projeto de mestrado é uma evidência. O projeto inicial apresentado seria um estudo de caso, um projeto de intervenção sobre um objeto determinado, tal qual se faz no estrangeiro. 
capítulo 3

inventando moda e costurando história:

pensamento e trabalho prático 
As ciências não estão equipadas para lidar com a metáfora. ${ }^{108}$

A frase acima, de J.G. Ballard, parece resumir o conteúdo de nossa discussão neste capítulo. Até aqui, procuramos apresentar as principais idéias que vêm acompanhando as atividades e a construção do ideário da conservação/restauração neste final de milênio. Agora, neste terceiro capítulo, estaremos discutindo particularmente as especificidades da conservação de têxteis históricos e a pouca ou maior proximidade entre teoria e trabalho prático. O que foi discutido até aqui, agora voltará projetado quer nas discussões dos estudos de caso que serão apresentados, quer nos comentários sobre a ética específica da atividade.

A área de conservação de têxteis trabalha, hoje, com duas linhas principais de abordagem, diríamos. Uma primeira, acreditamos, seria aquela que privilegia os aspectos estéticos de um objeto e por eles justifica seus métodos de

${ }^{108}$ No original em inglês "Sciences are not equipped to deal with the metaphor".J.G.Ballard The Thousand Wounds IN: A USER'S GUIDE TO THE MILLENNIUM. Essays and reviews. London, Harper Collins Publishers, 1997, p.161. 
intervenção e filosofia de preservação. Situa-se nessa linha, por certo, a Fundação Abegg, na Suíça, que mantém inalterados seus métodos de trabalho desde os anos 60. Uma segunda linha, menos intervencionista, mais engajada nas novas idéias de fim-de-século, seria aquela que defende a intervenção mínima, enfatizando o trabalho preventivo e justificando a restauração apenas como último recurso. Assim parecem trabalhar hoje, os principais museus e instituições internacionais, bem como os centros de formação profissional como o The Textile Conservation Centre (TCC), Inglaterra.

E, evidentemente, essas idéias, aqui simplificadas, podem ser detectadas na produção específica da área têxtil e devem, no caso do Brasil - onde inexiste a tradição de preservação dessa tipologia de objetos e onde se esboçam , apenas, os primeiros trabalhos -, ser entendidas e, se reproduzidas, situadas dentro do contexto mundial no qual se originaram.

Os anos 70 podem ser considerados decisivos para a área de Conservação de Têxteis. Até então, qualquer teorização envolvendo discussões ético-filosóficas, métodos de abordagem e conhecimentos técnicos, persistiam tendo por base, quer a bibliografia, quer os pressupostos de análise estabelecidos para as áreas de Conservação e Restauração de Monumentos Arquitetônicos e Pinturas, vigentes desde o século XIX.

Um objeto têxtil parecia, até então, ser pensado apenas em sua tridimensionalidade, enquanto escultura, construção, cujas partes e eventuais grafismos precisavam, sempre, ser restaurados e entendidos tais quais. Sua especificidade era apenas de ordem físico-química e seguiria, portanto, os mesmos sistemas de abordagem vigentes institucionalmente para todas as tipologias de objetos. 
Os anos 60 iniciariam a transformação efetivada na década seguinte. São publicados os artigos de James Rice, do Textile Museum, Washington; Dorothy Burnham e o Royal Ontario Museum apresentam o trabalho de sistematização da terminologia têxtil realizado pelos membros do C.I.E.T.A. (Centre International d'Étude des Textiles Anciens), em seis idiomas ; e na Suíça, é criada, em 1967, a Fundação Abegg, cujas atividades de curadoria passariam a sistematizar e divulgar toda a tradição escandinava, alemã e leste-européia na conservação de têxteis históricos.

Mas foi a década de 1970, todavia, aquela que trouxe, em definitivo, a sistematização do conhecimento da área. A reestruturação da atividade em grandes museus e a preocupação com a formação de um novo perfil de profissional, deram continuidade aos novos tempos. Publicam-se dois manuais importantes, os primeiros, acredita-se, inteiramente dedicados à conservação de têxteis: Textile Conservation, de J. Leene (1972) e The Care \& Preservation of Textiles, de K. Finch e G. Putnam (1977).

De características bastante diversas, ambos marcarão, definitivamente, os trabalhos dessa especialidade da conservação: o primeiro, evidenciando, qualitativa e quantitativamente a existência da área; o segundo, introduzindo idéias e propostas de ética e prática diferenciadas. O trabalho coordenado por Jentina Leene, ao reunir artigos dos principais centros e profissionais especializados na área têxtil, unificou, pela primeira vez, o repertório específico das práticas e abordagens vigentes.

The Care \& Preservation of Textiles (1977), é publicado dois anos após o início dos trabalhos de Karen Finch no Victoria \& Albert Museum, Londres, e da fundação, por ela, do The Textile Conservation Centre, marcando o início do trabalho de formação acadêmica de profissionais conservadores naquele país. No mesmo ano de 1977, nos Estados Unidos, 
Nobuko Kajitani, hoje Conservadora-Chefe de têxteis do The Metropolitan Museum of Art, de Nova York, publica seu texto Preservation of paper and textiles of historic and artistic value, contribuindo, assim, para que a discussão teórico-metodológica das atividades de preservação de acervos têxteis se desse, efetivamente, em nível mundial.

A partir de então, multiplicam-se as publicações periódicas, inserções em manuais gerais e edições resultantes de encontros temáticos. Precisam ser destacados, aqui,o ensaio de Hanna Jedrezejewska Problems of ethics in the Conservation of Textiles, de 1980, e o livro de Sheila Landi, The Textile Conservator's Manual, editado em 1985 e ainda hoje, o mais completo e elaborado trabalho da área. Estes autores e suas respectivas atuações em grandes museus e centros de formação formalizaram, em pouco mais de dez anos, a área têxtil e suas especificidades dentro do contexto mundial das atividades de preservação.

No Brasil, ainda na década de 1980, foram realizados cursos introdutórios no CETIQIT, Rio de Janeiro, com profissionais estrangeiros e apostilas precariamente traduzidas $^{109}$. Em termos de atividades práticas, oficialmente foram o Museu Histórico Nacional e posteriormente o Museu da República as primeiras instituições museológicas a trabalharem com acervos têxteis de forma diferenciada, embora não o fizessem, ainda, dentro dos padrões internacionalmente recomendados ${ }^{110}$.

\footnotetext{
${ }^{109}$ Ambos os cursos patrocinados pela UNESCO foram realizados no CETIQT (Centro de Tecnologia da Indústria Química e Têxtil - SENAI). A bibliografia apresentada consistiu na fraca tradução de 13 artigos do cientista americano James Rice, produzidos na década de 1960, ou seja, mais de vinte anos antes! James W Rice. Conservação de têxteis. Rio de Janeiro, CETIQT/SENAI, 1987. 325p.

${ }^{110}$ É difícil estabelecermos um histórico das atividades no país. Há dois anos ao ministrar uma disciplina de pós-graduação em curso de especialização da Universidade Federal de Pelotas, RS, conheci naquela cidade o Museu Casa da Baronesa. Aquele museu não só dispõe de uma coleção têxtil incomum, como teve sua museografia trabalhada por uma
} 


\title{
1. Trabalho mágico, trabalho básico: imaginário e cotidiano.
}

\begin{abstract}
As coleções unem. As coleções isolam. Elas unem os que amam a mesma coisa (mas ninguém como eu; o bastante) Elas isolam dos que não compartilham essa paixão.(Infelizmente, quase todos). Então vou falar sobre o que mais interessa. Falar sobre aquilo que interessa a você. ${ }^{111}$
\end{abstract}

O trabalho de conservação/restauração, a despeito do perfil artístico ou científico que se propague em determinado momento e sociedade, é quase sempre muito diverso da imagem construída por outros profissionais de museus e sociedade em geral. Primeiro, porque o trabalho de conservação e restauração envolve um grupo de atividades bem mais amplo do que se supõe, com atividades de natureza, objetivo, prática e duração diferenciados; segundo porque geralmente o efeito visual obtido, mesmo nas operações mais simples, conduzem, inevitavelmente, à esta interpretação por parte do público não especializado: o muito pouco, acaba parecendo bastante.

O trabalho de conservação rotineiro quase sempre é básico e não demanda pesquisa apesar de sabermos que este básico é um básico bastante especializado, construído por muitas leituras, estágios e especializações.

especialista americana, levada à cidade de Pelotas pela própria família e que a pedidos recriou, no museu, uma sala fiel à exposição do The Costume Institute-Metropolitan Museum de Nova York e outra fiel à exposição do Museu Hermitage em São Petersburgo.

${ }^{111}$ Susan Sontag, op.cit. p. 32 
Diferentemente do que se supõe para um contexto universitário, quase nunca há tempo para o aprofundamento de hipóteses surgidas durante os trabalhos.

No caso dos têxteis as informações sugeridas e necessárias são de três (ou quatro) níveis distintos:

- matéria-prima e beneficiamento;

- design, criação, forma, gosto;

- aplicação (transformação do tecido em outro objeto).

- nova transformação.

Uma das grandes dificuldades encontradas na conservação de têxteis é a existência pouco expressiva, ainda, de pesquisadores e produção em áreas correlatas como história da indústria têxtil e da indumentária no Brasil, por exemplo. Quase tudo ainda está por fazer. Os objetos históricos, assim, são quase sempre abordados como se fossem arqueológicos dado o percurso de pesquisa e procedimento que originam. Quase nada se sabe sobre os materiais e técnicas encontradas: como, onde e por quem eram produzidos determinados objetos ? Como eram beneficiados ? Uma luva, um móvel estofado e um brinquedo, por exemplo, são produtos, testemunho de relações e contextos de produção totalmente diversos, mas quais foram eles ?

Um bom exemplo das questões não respondidas e de eventuais erros de interpretação e leitura, é a falta de informação sobre os pigmentos e processos de tintura desenvolvidos no Brasil. Há muito já concluimos, nestes anos de trabalho, que os pigmentos azuis utilizados nos séculos XVIII e XIX, não necessariamente o índigo, passam por um processo de oxidação, transformam-se e mesmo desprendem-se, ocasionando uma mudança na cor dos tecidos. Uma série de têxteis hoje aceitos como amarelos, por exemplo, eram originalmente verdes. E assim por diante, com muitas outras colorações. Mas hipóteses 
requerem comprovação que requer pesquisa que por sua vez requer tempo disponível $^{112}$.

Outra dificuldade comum, por exemplo, diz respeito à ergonometria. Homens e mulheres nos séculos anteriores e parte deste, tinham outras proporções e outra avaliação sobre o que era pequeno, grande, gordo ou magro $^{113}$. E o mesmo acontece em relação a determinados hábitos como bordar lenços com fios de cabelo, alterar bandeiras e dobrar a ponta dos chapéus. Infelizmente, apenas hipóteses. Mas a falta de informações, entretanto, não se resume à área histórica. Pouco ou quase nada conhecemos sobre os efeitos e utilização dos materiais estrangeiros em nossa realidade climática: adesivos, polímeros, materiais de embalagem, tecidos ${ }^{114}$.

Se a falta de informações sobre os objetos e materiais pode ser considerada uma característica de contexto, geográfica e temporal, a diversidade de tipologias e matéria-prima deve ser aceita como uma

\footnotetext{
${ }^{112}$ Esta relação cor-contexto aplica-se muitas vezes a tons e nuances de uma mesma cor e deve, em princípio, ser considerada antes de submetermos um artefato a um tratamento de conservação. Este é o caso dos brancos, por exemplo, nos diferentes períodos históricos. Sabe-se, que os diferentes tons de branco existentes nos séculos XVI, XVII, XVIII e XIX são bastante difíceis de serem estabelecidos ou reestabelecidos. Registros do século XVIII, referem-se a diferenças nos preços das rendas de acordo com o nuance de branco desejado. Segundo Pat Earnshaw, autora de um estudo sobre o assunto, não podemos submeter uma renda branca do século XVI, por exemplo, a uma lavagem aquosa com detergentes comerciais. Não podemos assumir tal procedimento, afirma, não porque eles possam trazer ao têxtil elementos indesejáveis à sua preservação, mas porque estes introduzirão no objeto, necessariamente, branqueadores ópticos que lhe darão características branco-azuladas, que uma renda, com essa datação, não poderia jamais conter. Vide Pat Earnshaw. BOBBIN \& NEEDLE LACES: identification \& care. London: B\&T Batsford, 1983. 191p. il. ;e Bernard Guineau Acquisition et traitement de donées colorimétriques; aplication à l'étude de la teinture des textiles. IN LA CONSERVATION DES TEXTILES ANCIENS. Journées d'Études de la SFIIC. Angers, out.94, pp. 53-68.
}

113 A literatura é rica em exemplos: quase todos os romances de José de Alencar, por exemplo, nos mostram isto, em especial A Pata da Gazela, cujo argumento é centrado no tamanho dos pés e no preconceito para com os pés grandes, ou "ingleses".

${ }^{114}$ Quase tudo, no Brasil, se comporta de forma diferenciada, isto sem contar que materiais comercializados com o mesmo nome lá e cá, quase sempre são diferentes. 
característica da especialidade. O termo têxtil, como já vimos, engloba inúmeras possibilidades de forma e materiais. Se até a Primeira Guerra ambos eram limitados, anos depois já se encontravam em infinitas derivações. O mundo plástico, da obsolescência programada, não parou de crescer seja em formas seja em materiais. As fibras têxteis- que até o surgimento do nylon-, podiam ser resumidas a quatro básicas algodão, linho, seda e lã-, hoje se encontram divididas em dezenas de grupos dentre artificiais, sintéticas, químicas e inorgânicas. Some-se à tanta diversidade, ainda, o fato da maioria dos objetos têxteis ser de natureza composta, apresentando outros materiais como metal, couro, borracha, plumária, ossos e peles, vidro e plásticos ${ }^{115}$.

Imaginemos, por exemplo, o que podem ter em comum uma ovelha, um pé de algodão e um litro de petróleo. Os três são compostos orgânicos ${ }^{116}$, evidentemente, mas se colocarmos água sobre o petróleo, dermos alimento ao pé de algodão e irrigarmos a ovelha poderemos rapidamente aniquilá-los, alterar suas características ou, na melhor das hipóteses, nada acrescentar-lhes. Parece evidente, portanto, que tanta diversidade de origem se mantenha ao derivar-se em materiais e produtos, ainda que sob o mesmo nome: fibras, fios e tecidos.

Antes de mais nada é preciso entendermos que todo tecido leva consigo as vantagens e desvantagens da matéria-prima da qual foi feito e dos processos físicos e químicos utilizados em sua produção. Assim, a melhor ou pior conservação de uma fibra, e conseqüentemente de um artefato, dependerá das

\footnotetext{
${ }^{115}$ Aqui vale a pena introduzirmos um comentário pessoal. É justamente em tanta diversidade, em tanto a descobrir e aprender que se encontra o grande fascínio desta área sobre todas as outras que, geralmente, apenas trazem as variações do mesmo !

116 Sobre a classificação dos materiais vide THE CONSERVATION UNIT - SCIENCE FOR CONSERVATORS - INTRODUCTION TO MATERIALS. London, The Conservation Unit of the Museums \& Galleries Commission/Routledge, 1992, vol 1, p.16.
} 
características de alongamento e elasticidade, rotura, capacidade térmica, solidez ao alvejamento, natureza higroscópica, etc do material que o compõe $\mathrm{e}^{117}$.

Ainda quando classificadas em um mesmo conjunto, como por exemplo, fibras animais, fibras celulósicas ou químicas, a diversidade permanece grande. Basta pensarmos o que há em comum entre a girafa e o peixe, ambos animais ou entre um côco e um caqui, ambos frutas, para compreendermos que apresentam estruturas muito diferenciadas e que sua preservação, portanto, dependerá de fatores e condições igualmente diferenciadas. A diversidade é, portanto, a principal característica da especialidade.

Entretanto tanta diversidade na origem e nas formas de construção vem requerer igual diversidade - quase sempre, - somente na análise e definição da metodologia do trabalho. As operações sobre os artefatos, todavia, são poucas, elementares, e quase sempre as mesmas. Como acontece com as demais tipologias, trabalha-se com materiais e técnicas pertinentes ao suporte: no caso de têxteis, portanto, com fios, agulhas, tecidos e costura ${ }^{118}$. Anos atrás, dois profissionais apresentaram em congresso especializado um texto muito interessante que discutia, dentre outras, a hipótese de que os tratamentos de conservação tenham sido influenciados pelas atividades comerciais e abordagens domésticas dos materiais envolvidos. A conservação de têxteis seria, então, herdeira do trabalho de manutenção doméstica dos têxteis, tendo desenvolvido

\footnotetext{
${ }^{117}$ Existem muitos manuais e livros no mercado que explicitam, em detalhe, os processos de obtenção de cada uma das matérias-primas citadas, características e processos mais comuns de beneficiamento. Vide: Gohl; Vilensky. TEXTILE SCIENCE: an explanation of fibre properties. Melbourne: Longman Cheshire, 1983.217p.il.

${ }^{118}$ Evidentemente que aquilo que aqui chamamos de básico pode atingir níveis altíssimos de sofisticação, caso se mostre necessário e se fará mais evidente com a discussão dos estudos de caso.
} 
métodos de trabalho que envolvem e privilegiam a limpeza em meio aquoso, o detergente, a agulha e a linha como instrumentos ${ }^{119}$.

Em nosso caso específico, tudo leva a crer, tem sido a característica de contexto ao invés das características da especialidade, o elemento determinante sobre as tomadas de decisão, eleição de prioridades e mesmo orientação metodológica das intervenções e pesquisas. E aqui já cabe uma primeira indagação: será que isso faz sentido na Universidade ? Antes de iniciarmos qualquer discussão é necessário apresentarmos as principais variáveis de trabalho num contexto institucional e universitário.

O trabalho de conservação de têxteis no Museu Paulista/USP compreende -quase sempre-, atividades de intervenção de diferentes características e objetivos. São elas basicamente:

a. conservação de objetos para exposições de curta e média durações. Aqui a natureza do trabalho sobre os objetos, quase sempre, é definida pelo cronograma e pela condição expositiva à qual serão submetidos;

b. conservação de objetos para fotografação elou consulta. Neste caso são trabalhados objetos que, de outra forma, não seriam alvo de atenção imediata. Como no caso anterior, o objetivo final é determinante da ação;

c. conservação de objetos para armazenagem de longa duração. Aqui são trabalhadas as diversas coleções, muitas vezes objeto de estudo dos programas de estágio. Não há cronograma. É uma atividade sistemática que

${ }^{119}$ Vincent Daniels e Yvonne Shashoua, Wet cleaning of paper and textiles: similarities and differences, IN: PAPER AND TEXTILES: THE COMMON GROUND, Glasgow, 1991. Preprints. Glasgow, The Scottish Society for Conservation \& Restoration (SSCR), 1991. 136p. il. 
procura encontrar novas soluções, materiais adequados e compatíveis às tipologias como um todo;

\section{d. conservação de objetos para exposições externas (antes e depois).}

Este trabalho, de cronograma e objetivos dados, envolve desde pequenos reparos até projetos de embalagem, transporte e exposição;

\section{e. tratamentos completos de conservação (projetos de intervenção,}

propriamente ditos). Neste grupo se incluem os objetos cuja ação sobre, qualquer que seja, demanda pesquisa em níveis diversos, consulta a especialistas, exames e documentação diferenciada;

f. trabalhos em situações emergenciais. São aqueles ocasionados por acidentes, naturais ou não.

g. conservação de objetos de outras instituições. São trabalhos que exigem a elaboração de um projeto completo de conservação, como já definido anteriormente.

Desde o início das atividades, as unidades de acervo foram trabalhadas nas seguintes proporções:

\begin{tabular}{lcccc|}
\hline conservação para: & $\mathbf{1 9 9 4}$ & $\mathbf{1 9 9 5}$ & $\mathbf{1 9 9 6}$ & $\mathbf{1 9 9 7}$ \\
\hline a. exposições & 49 & 26 & 20 & 48 \\
\hline b. fotografação e consulta & - & - & - & 3 \\
\hline c. armazenagem de longa duração & 55 & 39 & 07 & 15 \\
\hline d. exposições externas & & & 25 & 25 \\
\hline e.projetos de intervenção & 12 & 7 & 10 & 8 \\
& & $(12-5)$ & $(7$ - 3$)$ & $(10-2)$ \\
\hline f. trabalhos emergenciais & 2 & 6 & - & 1 \\
\hline g. projetos de outras instituições & & & 1 & \\
\hline
\end{tabular}


Esta quantificação precisa ser interpretada, todavia, levando-se em conta que:

I- o profissional-setor ${ }^{120}$, ocupou-se com diferentes atividades igualmente importantes durante aqueles anos: cursos, publicações, palestras, assessorias, participação em congressos e atividades internacionais etc.

II- desde o início das atividades foram priorizadas as seguintes situações:

1) de objetos em estado crítico, de acesso quase impossível. Este grupo de acervo era formado por objetos diferenciados como vestidos, leques, bandeiras etc - todos não casualmente em seda-, que se estavam desintegrando ou já desintegrados, não podendo ser manipulados, removidos e documentados $^{121}$. São exemplos deste grupo o vestido da Marquesa de Santos e uma Bandeira da Guarda Nacional de São Paulo.

2) de objetos “desenganados”, para fins de pesquisa. Este grupo de acervo, assim apelidado, era composto por objetos ou fragmentos de objetos em situação aparentemente irreversível de deterioração. Exemplifica este grupo uma Barretina de 1898, cujo interior em papelão foi atacado por cupins, tirando-lhe a sustentação e transformando a antiga estrutura de couro, pele e metal, numa massa disforme e rígida ${ }^{122}$.

\footnotetext{
${ }^{120}$ No momento em que este texto foi escrito, todos os profissionais conservadores da Universidade de São Paulo, ao todo sete, incluindo Museu Paulista, Museu de Arte Contemporânea, Museu de Arqueologia e Etnologia, Comissão de Patrimônio Cultural e L.I.S.A. (Laboratório de Imagem e Som em Antropologia) respondem individualmente por um Setor.

121 As fibras animais, especialmente a seda, não encontram nos climas tropicais o meio adequado à sua preservação. Além disso, sabe-se, a maioria da seda produzida no século XIX, conhecida como heavy silk, apresenta um processo peculiar de deterioração devido ao elemento metálico (chumbo) que lhe era introduzido para aumentar seu peso.

${ }^{122}$ A Barretina, ainda em tratamento (1994-1998), voltou a ser chapéu e aguarda, agora, a definição do material e confeccção de um suporte definitivo.
} 
3) de objetos cuja complexidade exigia um projeto completo de conservação. Este grupo de acervo é composto por objetos que demandam pesquisa aprofundada.

Se a característica de contexto, como afirmamos anteriormente, é de fato aquela que acaba determinando o rumo dos trabalhos desenvolvidos, será que estas atividades realmente fazem sentido $?^{23}$ Esta preocupação constante talvez justifique muitas das escolhas e prioridades dadas aos objetos trabalhados nestes anos de atividade. Os objetos têxteis, principalmente indumentária, parecem "agradar" especialmente ao público do museu. Este "sucesso" obrigou-nos a reconsiderar padrões ideais para sua exposição e rever vários outros pontos do credo, internacionalmente reconhecidos ${ }^{124}$. As teorias e ideário

\footnotetext{
${ }^{123}$ O Museu Paulista quer se goste ou não é um museu $d a$ Universidade e não um museu universitário. Sua localização e histórico são e serão sempre predominantes. Um museu histórico, popular,.... a segunda maior visitação do país. Nos meses de julho a outubro a média diária de visitação pode chegar a 3.000 pessoas, o que no Brasil é bastante raro. A situação entusiasmante, em teoria, é motivo de orgulho das autoridades universitárias e frequientemente é utilizada para engordar discursos e relatórios sobre a atuação da USP junto a sociedade que a sustenta. Mas a realidade de quem ainda se importa, daqueles que lá trabalham por opção é quase sempre fonte de angústia e desapontamento. O Brasil que visita o museu, não é o Brasil que parece interessar à Universidade. É o Brasil feio, inculto, pobre, ao qual o discurso universitário não consegue atingir. É a pedra no sapato a nos apontar, cotidianamente, que há algo errado, muito errado. Curiosamente, lá no Ipiranga, talvez, estivesse a chance de realmente produzirmos, marcarmos pontos, construirmos alguma diferença. Mas a despeito dos discursos e cerimônias constantes, permanecemos trabalhando para nós mesmos, ignorando o verdadeiro patrão, o para quê e a razão de estarmos lá.

${ }^{124} \mathrm{Um}$ desses pontos diz respeito a luminosidade ideal. Há um fato real: os têxteis são irreversivelmente afetados pela luz. Assim, recomenda-se expô-los em baixa luminosidade (50 lux, o que é muito pouco). A primeira exposição de têxteis realizada nestas condições provocou uma reação imediata daquele público: os visitantes paravam na porta e não entravam no ambiente escurecido. Foram necessárias várias modificações para reverter a situação. O exagero conservativo ali, ficou evidente! Outro desses pontos dizia respeito a objetos que dada a sua fragilidade não poderiam ser expostos. A questão, de imediato, apontava o constrangimento, a regra-tolice. Será que vale a pena preservarmos um objeto que não pode ser exposto ? Tal questão adquire peso e significado bastante diferenciados quando colocada por um conservador.
} 
internacionais, que se haviam mostrado de fácil adesão teórica, tornavam-se por demais alienígenas e mesmo sem sentido durante alguns dos trabalhos práticos.

\section{O memento hominem, o encantamento no trabalho e a ética}

\section{profissional}

Bom é o que eu quero, verdadeiro o que represento em meu espírito. Vontade e representação que podem ser, no nível de uma psicologia atomizada e sensualista, capricho e auto-ilusão. E no intervalo entre prazer e dor, o sujeito se arrasta no tédio, poeira que enche as horas neutras de saciedade e alívio. Mas o tédio prolongado também é letal, daí a necessidade da ação, incerta embora e pontuada de riscos. ${ }^{125}$

Por quais razões alguém escolhe ser conservador e, em que medida, tais razões acabam por influenciar diretamente a interpretação e as intervenções sobre os objetos ? A resposta não é simples e talvez não seja o caso de tentarmos construí-la.

Nos capítulos anteriores vimos que as atividades de conservação hoje andam sendo diretamente influenciadas por uma série de idéias, por um contexto externo, diríamos. Mas se assim acontece, também é verdade que existem outros valores, um contexto interno, a determinar certas escolhas individuaisprofissionais: rodearmo-nos de objetos- afirma Susan Sontag,- nos garante que os sentidos nunca fiquem desocupados, nem a imaginação sem exercício ${ }^{126}$.

J.G. Ballard é autor de um conto muito intrigante no qual o personagem central da história - um homem que comprara um manequim para lhe fazer

\footnotetext{
${ }^{125}$ Alfredo Bosi (comentando o poeta Leopardi) O Tempo e os Tempos IN: TEMPO E HISTÓRIA. São Paulo, Cia das Letras, 1992, p.25.

${ }^{126}$ Susan Sontag, op.cit. p. 342.
} 
companhia -, descobre que sua boneca era na verdade uma mulher taxidermizada e então se apaixona: "Agora eu soube que aquela pessoa sentada em sua cadeira dourada não era um manequim, mas o que um dia fora uma mulher com sua têz incomparável fixada e para sempre preservada por um mestre, não das bonecas, mas da arte da taxidermia. Naquele momento eu me apaixonei profundamente por Serena Cockayne” ${ }^{127}$.

Com esta imagem forte gostaríamos de introduzir um elemento a mais às discussões que vêm sendo feitas e que ainda virão. Tal qual o colecionador, talvez, o conservador expresse seus desejos e seu prazer no ato de conservar. Talvez seja esta a sua maneira de reivindicar sobre os artefatos um determinado tipo de posse, de valorizá-los e valorizar-se. Talvez aí exista algum entendimento, um acordo sensível nem sempre explícito e quase nunca consciente. Mas é evidente, como em qualquer outra atividade, que existe a afinidade por determinados suportes e um grau maior ou menor de apaixonamento por este ou aquele objeto. Dificilmente um conservador especializado em uma tipologia darse-á bem trabalhando com outros materiais. $\mathrm{O}$ toque quente ou frio, as texturas e odores, a sedução do olhar para determinados detalhes, cores e variáveis encontradas. São tais sentimentos e sensações, quase sempre, os responsáveis

127 "Now that a nightmare logic has run its course, it is hard to believe that my friends and I thought it the most innocent caprice when I first brought Serena Cockayne to live with me in my Chelsea House...... Of course Serena never took part in any of our conversations, and no doubt this was a vital element on her appeal.... She was the kind of woman that men invent... It is curious that it took me so long to realize that I was looking, not at a real young woman. but at a masterpiece of the doll-maker's art produced by a remarkable virtuoso..... I knew now that the person seated on her gilt chair was no manikin but a once living woman, her peerless skin mounted and forever preserved by a master, not of the doll-maker's but of taxidermist's art. At that moment I fell deeply in love with Serena Cockayne......It is cold here, as the low temperature helps to preserve Serena. By turning on the heating system I could probably dispose of her in a few weeks, but this I can never do. That smirk of hers alone prevents me. Besides, I am completely bound to Serena.Fortunately, Serena is now ageing faster than I am. Helplessly watching her smile, I wait for her to die and set me free." J.G. Ballard The Smile IN: MYTHS OF THE NEAR FUTURE. London, Vintage Books, 1994.p. 164-177 
por uma maior ou melhor qualidade nos resultados. Afinal, o que faz de alguém um especialista, senão apaixonamento e obsessão ? Mas será que é permitido pensar assim?

Seria bastante interessante se pudéssemos elencar, quantitativamente, os elementos determinantes presentes à sensibilidade dos conservadores. Talvez nos surpreendessemos chegando a um grupo predominante, constante, de vetores sensíveis que, dentre outros, poderiam ser: sutileza, curiosidade, autoridade, ambigüidade, gosto pelo antigo, pela novidade e talvez pela fantasia.

A sutileza física ou intelectual, a curiosidade trazida pela novidade constante e a autoridade existente na decisão e no hands on parecem inerentes ao trabalho de conservação ${ }^{128}$. Já a ambigüidade e o gosto pela fantasia nem tanto: assim como na Teogonia ${ }^{129}$ tais vetores da sensibilidade encontrar-se-íam hierarquizados e explicitados nos profissionais conservadores em diferentes combinações, proporções e elementos dominantes como nos sugere Italo Calvino $^{130}$. Cada artefato assim, do ponto de vista do conservador, seria um puzzle, uma fonte de encantamento e fascínio a gerar entusiasmo ${ }^{131}$ e quem

\footnotetext{
${ }^{128}$ Sobre a autoridade no museu ver Crew \& Sims, Locating authenticity IN: KARP, Ivan; LAVINE Steven (ed). EXHIBITING CULTURES: The Poetics And Politics Of Museum Display. Washington: Smithsonian Institution Press, 1990, p.163.

${ }^{129}$ Refiro-me à TEOGONIA, de Hesíodo, e sua classificação dos deuses em superos, ínferos, etc.

130 "Cada vida é uma enciclopédia, uma biblioteca, um inventário de objetos, uma amostragem de estilos, onde tudo pode ser continuamente remexido e reordenado de todas as maneiras possíveis Italo Calvino, SEIS PROPOSTAS PARA O PRÓXIMO MILÊNIO - (s/a rapidez). São Paulo, Cia das Letras, 1994, p. 67.

${ }^{131}$ Entusiasmo aqui entendido como o elemento a nos projetar as mudanças, uma alegria com projeto a compensar o enfado e o prosaísmo do mundo. Assim o define Renato Janine Ribeiro em O Entusiasmo, o teatro e a revolução IN TEMPO E HISTORIA. op cit., p. 314.
} 
sabe remetê-lo ao sublime ${ }^{132}$. Concomitantemente estariam em ação, igualmente, o medo, a insegurança, o sentimento de impotência ${ }^{133}$.

Seguindo este raciocínio poderíamos afirmar que os objetos proporiam e aí não mais exclusivamente aos conservadores-, um percurso inverso ao da ficção literária, possibilitando a construção de enredos e autorias as mais diversas ${ }^{134}$. Dentro do contexto ficcional museológico o conservador atuaria,

${ }^{132}$ Raymond Bayer define dois sublimes: o dinâmico e o matemático. O conservador, dependendo de sua hierarquia sensível, experimentaria mais um ou outro modo.

"o sublime dinâmico sublime de força, manifesta-se quando nos encontramos diante de certas forças que excedem infinitamente as nossas próprias forças; somos humilhados e tomamos consciência da nossa impotência. É portanto a potência que está no centro do problema, é uma força superior a grandes obstáculos..... sublime dinâmico suscita portanto o medo. $O$ homem, sob o império do temor, não pode julgar o sublime, tal como o homem dominado pela inclinação e pelo apetite não pode julgar o belo....Enquanto seres da natureza, essa potência obriga-nos a reconhecer a nossa fraqueza.

o sublime matemático é um belo aristotélico; é o sublime da grandeza, como o infinito do céu: a imaginação representando-se os milhões e milhões de estrelas, os anos-luz. É um puro juízo de reflexão apropriado subjectivamente a um certo emprego das nossas faculdades de conhecer. É sublime aquilo em comparação do qual tudo é pequeno. É o grande absolutamente. Nada do que pode ser objecto dos sentidos (tudo lhe é relativo) nem do que releva do número (toda a quantidade matemática é relativa) pode ser sublime. É a disposição do espírito que é sublime, não o objecto; só nela se encontra o absolutamente grande. Precisa do "indício" duma faculdade de alma que ultrapassa toda a medida dos sentidos", É um jogo da imaginação. O sublime, isto é, o que é grande esteticamente e infinitamente, sobrevém quando o acto de apreensão do sensível não pode ser seguido pelo acto de compreensão da imaginação. $O$ infinito é grande absolutamente, e contudo a razão quer concebê-lo como um todo. Este facto exige da alma humana uma qualidade supra-sensivel: a razão “

Raymond Bayer, HISTÓRIA DA ESTÉTICA. Lisboa, Editorial Estampa, 1979. p. 204-205

${ }^{133}$ Diferentemente do que ocorre com a medicina, por exemplo, onde existem médicos e cirurgiões, profissionais mais "ativos" ou mais "passivos", a área de conservação exige profissionais "completos". Mentem os que negam ter medo de causar um dano, os que postulam jamais terem se equivocado durante uma intervenção.

${ }^{134}$ Talvez esta seja uma possibilidade mais constante nos museus de história e etnografia do que nos museus de arte; não saberíamos dizer. O estudo de qualquer artefato para fins de conservação pressupõe um período mínimo de convivência com ele. Examina-se cada detalhe, cada alteração ou dano sofrido, olha-se, observa-se minuciosamente tudo. No caso dos têxteis, quase sempre, gasta-se algum tempo para entendê-lo como forma, como engenharia, até que num determinado dia olha-se para ele- mesmo quando muito fragmentado-, e tudo passa a fazer sentido). Neste intervalo de tempo são inevitáveis as perguntas que surgem: por onde andou este objeto, quando terá sido usado e quem o terá usado ? Teria o seu proprietário sido feliz ? Qual seria o seu projeto de felicidade ? Como 
quer ele assim se proponha ou não, como um interlocutor ativo a escolher, interpretar, direcionar sua ação prática - ainda que científicamente - conforme seu gosto, sua sensibilidade, sua formação intelectual, suas crenças individuais e mesmo sua psique. Mas será que este grande teor ficcional, não objetivo das atividades, é percebido pelos profissionais conservadores e demais especialistas de museus? Aparentemente não. Um exame rápido sobre os trabalhos apresentados em congressos e reuniões científicas quase sempre aponta para um excessivo propagandear de certezas e objetividades inúteis.

Nosso mundo não cabe no mundo ${ }^{135}$, afirma-se. Se assim o é, contudo, se cada indivíduo vem resguardado em sua própria autonomia, em que bases se pode estabelecer a vida social, indaga o filósofo Gerd Bornheim ${ }^{136}$ No mesmo sentido reflete Eduardo Gianetti em seu ensaio sobre o Auto-engano: “(...) quando se trata de atribuir a devida dimensão e dar um contorno adequado ao que se refere a nós mesmos, quando o que está em jogo é a definição de uma perspectiva equilibrada entre os nossos interesses e os interesses dos que nos cercam, cuidando para que as nossas ações reflitam na prática esse equilíbrio, a nossa capacidade de discernimento e juízo moral tende a ficar seriamente enfraquecida. A contigüidade no tempo e no espaço, de um lado, e a proximidade no afeto e no interesse, de outro, interferem de forma poderosa no funcionamento das faculdades morais. A competência humana para ver e julgar com um mínimo de isenção e imparcialidade parece cair exponencialmente à medida que nos aproximamos de tudo aquilo que nos afeta e preocupa de perto." 137

teria morrido ? O que diria ele se supussesse que alguma coisa sua, pessoal, seria exposta publicamente em um museu?

${ }^{135}$ Eduardo Gianetti, AUTO-ENGANO. São Paulo, Cia das Letras, 1998, p. 81.

${ }^{136}$ Gerd Bornheim, O sujeito e a norma IN: ÉTICA. São Paulo, Companhia das Letras, 1994, p. 252. 
Nestes termos, portanto, qual o limite dos sentimentos individuais, indague-se, sobre os resultados profissionais? Poderíamos deduzir que a profissão de conservador, dentro da perspectiva apresentada, esteja necessariamente ligada ao trabalho artístico e quase nunca ao científico ? Como se define hoje, em conservação, atitude profissional ? Será que são as ciências que não admitem o metafórico, o subjetivo ou será que a dificuldade parte daqueles que a manipulam?

Geralmente aceita-se como definição de atitude profissional a combinação de dois atributos básicos: auto-consciência e senso de responsabilidade. Não apenas uma capacidade para, mas uma certeza de, diferenciando o conhecer as regras profissionais do agir profissionalmente. ${ }^{138}$ Esta definição, curiosamente, parece remeter-nos outra vez ao politicamente correto. Dentre a bibliografia trabalhada não encontramos explicitado em texto algum o que se entende por senso de responsabilidade. Aliás, os diversos códigos internacionais de ética profissional estão repletos de expressões vagas como essa. Vejamos este exemplo extraído de estudo recente: "O ICOM estabelece que o conservador/restaurador trabalhando em estreita colaboração com curadores e outros profissionais, deve distingüir o que é necessário do que é supérfluo; o possível do impossível; a intervenção que traz à luz as qualidades do objeto daquela que é danosa para sua integridade (leia-se autenticidade)". ${ }^{139}$ O que postula verdadeiramente um código de ética que se

\footnotetext{
${ }^{137}$ Eduardo Gianetti, AUTO-ENGANO. São Paulo, Cia das Letras, 1998, p. 178

138 vide, dentre outros, Janey Cronyn \& Dinah Eastop Professional Attitude: The Challenge to Education with Particular Reference to a Post-graduate Programme. IN: ICOM COMMITTEE FOR CONSERVATION, 10th Triennial Meeting. Preprints. Washington, 1993, p. 721-725.

${ }^{139}$ sobre o conteúdo e análise crítica de alguns dos códigos de ética da área de conservação vide: Maria Helena Pires Martins, POLÍTICAS CULTURAIS DE CONSERVAÇÃO DO
} 
utiliza de palavras como necessário, supérfluo, possível e impossível? Será que existe algum sentido prático em colocações como a mencionada acima ? O que significa trazer à luz as qualidades de um objeto ?

$\mathrm{Na}$ área específica de conservação de têxteis tomemos como referência, quatro textos que se ocuparam em discutir e explicitar a aplicação de princípios éticos ao trabalho específico da tipologia, mais o Checklist do Departamento de Conservação do Victoria \& Albert Museum, adiante transcrito na íntegra. Todos, note-se, tornaram-se referência aos trabalhos desenvolvidos no Museu Paulista. São eles: Problems of ethics in the conservation of textiles (1980) de Hanna Jedrzewska; as páginas introdutórias de Metchild Flury-Lemberg ao seu TEXTILE CONSERVATION AND RESEARCH (1988); The making of a conservator (1985) de Sheila Landi; e Restauração e conservação: algumas questões para os conservadores. A perspectiva da conservação de têxteis (1994) de Mary Brooks et alli. ${ }^{140}$

Os dois primeiros textos, não casualmente ignorados pela bibliografia inglesa, foram pioneiros na tentativa de indicar padrões de conduta considerados convenientes. O texto de Hanna Jedrzewska inovou ao se dedicar

PATRIMÔNIO - CASO DO MOBILIÁRIO. São Paulo, Tese de Livre-docência apresentada à Escola de Comunicações e Artes da Universidade de São Paulo, 1997, 199p, p.96.

140 Hanna Jedrzewska Problems of ethics in the conservation of textiles IN: CONSERVAZIONE E RESTAURO DEI TESSILI: CONFERENCIA INTERNAZIONALE. Como: 1980, pp. 99-103. ; Metchild Flury-Lemberg. TEXTILE CONSERVATION AND RESEARCH. Riggisberg: Abegg-Stiftung, 1988. 532p.il ; Sheila Landi The making of a conservator.IN: THE TEXTILE CONSERVATOR'S MANUAL. 2.ed. London: ButterworthHeinemann, 1992. 340p. il. p. 3-7. ; Mary Brooks, Caroline Clark, Dinah Eastop e Carla Petschek "Restauração e conservação: algumas questões para os conservadores. A perspectiva da conservação de têxteis" IN ANAIS DO MUSEU PAULISTA. São Paulo, N.Ser. v.2 jan/dez 1994. (Tradução Teresa Cristina Toledo de Paula) ;VICTORIA AND ALBERT MUSEUM CONSERVATION DEPARTMENT - USING THE ETHICS CHECKLIST. APUD: Jonathan Ashley-Smith A consistent approach to a varied collection. IN: Restoration. IS IT ACCEPTABLE? BRITISH MUSEUM CONFERENCE, London, British Museum, p. 92/93. 
exclusivamente aos têxteis. Nele encontram-se relacionados vários procedimentos considerados corretos e se questionam outros tantos até então nunca discutidos como a recuperação de cores perdidas ${ }^{141}$, a transferência de áreas bordadas para novos suportes $^{142}$ e a forma de expor tecidos já trabalhados ${ }^{143}$. Aparentemente, dentro da especialidade, a autora foi a primeira profissional a questionar o princípio da reversibilidade: "em sua intenção teórica , a reversibilidade é uma exigência bastante razoável....mas muitas vezes, a despeito das aparências, a alegada irreversibilidade simplesmente não existe. Primeiramente, a limpeza é e sempre será um processo irreversível. Além disso, a reversibilidade será mais viável em tratamentos mecânicos do que em tratamentos químicos, embora a remoção de costuras, usualmente considerada como reversível, deixe no tecido as marcas dos furos por ela causados....". ${ }^{144}$ Mais do que indicar ou definir condutas, entretanto, o texto já discutia métodos e práticas que ainda hoje são motivo de polêmica.

As idéias contidas no livro de Metchild Flury-Lemberg precisam ser analisadas dentro de sua realidade específica e única no mundo. A cientista suíça, pioneira na formação de profissionais europeus, foi responsável pela organização da Abegg-Stiftung, em Riggisberg, uma fazenda meio caminho entre Basel e Berna, que concentra a maior coleção de têxteis do planeta. Igualmente únicos são sua biblioteca e equipe de pesquisadores que, apoiados por uma infraestrutura perfeita e generosa, realizam um trabalho de pesquisa da maior

\footnotetext{
${ }^{141}$ Não se cogita na área têxtil - diferentemente de outras especialidades -, a possibilidade de recuperação das cores originais através de um novo tingimento. Algumas vezes, no caso dos brancos, adota-se tal procedimento.

142 Por muito tempo foi prática comum transferir-se áreas bordadas sobre tecidos deteriorados para novos suportes.

143 Aqui são várias as considerações da autora, mas podemos citar, em especial, sua preocupação com o hábito bastante difundido de expor os têxteis planos ou bidimensionais em total verticalidade, pressionados entre dois vidros ou "acrílicos".
} 
qualidade. A Fundação, iniciada com a coleção particular de seu criador Werner Abegg, organiza todas as suas atividades sobre uma premissa específica: $\underline{u m}$ tecido é uma obra de arte e como tal deve ser tratado. É dentro desta perspectiva exclusiva que todo o trabalho de conservação/restauração é realizado. Nesse contexto, afirma Flury-Lemberg, não há sentido na preservação de tecidos sujos, manchados e/ou rasgados, pois a beleza original do tecido precisa ser recuperada. A autora fala em respeito histórico, bom senso e respeito ao material original; em nenhum momento de seu texto, contudo, encontra-se a palavra ética. Seu livro, ricamente ilustrado, apresenta um grande número de objetos antes e depois de trabalhados além de trazer arrolados vários dos procedimentos e técnicas adotadas. Em linhas gerais o trabalho lá desenvolvido - no qual as atividades de todos os outros profissionais e laboratórios europeus se espelharam, - permanece pouco alterado desde 1967, sendo hoje bastante criticado, principalmente na Inglaterra.

Sheila Landi, justamente, surgiria com seu trabalho para sistematizar cientificamente o que aprendera na Suíça e dar novo perfil aos trabalhos desenvolvidos no Victoria \& Albert Museum até então. Seu texto introdutório procura descrever minuciosamente as qualidades essenciais de um profissional da área têxtil. Não é por acaso que a autora inicia seu texto deste modo: "I have been heard to say that if a person gives as a reason for wanting to be a conservator, 'I just love beautiful old things', they are automatically rejected. That may be an exaggeration of my reaction but the phrase does carry with it an unfortunately romantic view of the past, its products and our relationship with them. ${ }^{145}$ Buscava-se já a definição de um novo profissional que embora fizesse uso da tradição 'doméstica' da área têxtil apresentasse igualmente, uma conduta científica. Sheila Landi todavia não

\footnotetext{
${ }^{144}$ Hanna Jedrzewska, op.cit., p.102.
} 
explica, em seu texto, o que entende por trabalho ético. Ao discutir as idéias de reversibilidade, aplicabilidade dos materiais e a importância do estético nos objetos, ela se limita a sugerir cuidado com as generalizações e posturas pautadas em juízos prematuramente concebidos. Aparentemente, segundo a autora, ético seria todo o trabalho resultante de reflexão e da experiência: "it is unwise to form opinions too quickly. Wait until experience gives a proper basis upon which to form a personal judgment." ${ }^{146}$

O texto de Mary Brooks et alli, todos profissionais do The Textile Conservation Centre onde realizamos nossa especialização, é sem dúvida hoje a melhor discussão e interpretação das idéias de conservação/restauração dentro da área têxtil. $\mathrm{O}$ ensaio trouxe as principais questões presentes na bibliografia da especialidade numa nova 'roupagem', uma versão fim de século e politicamente correta. Todas as questões teórico-metodológicas parecem ter sido abordadas no texto: do processo de tomada de decisão às questões sugeridas pelas especificidades culturais; dos problemas colocados pelo mercado de arte à delicada relação entre conservadores e curadores. É importante notar-se, entretanto, que em momento algum é enunciada a possibilidade de um trabalho não ético, a sugerir talvez que esta seja já uma discussão ultrapassada e mesmo, que todo trabalho profissional seja, por condição, necessariamente ético.

Finalmente consideremos o Ethics Checklist do Victoria \& Albert Museum, adotado nos trabalhos de conservação de têxteis do Museu Paulista:

\section{VICTORIA AND ALBERT MUSEUM CONSERVATION DEPARTMENT \\ USING THE ETHICS CHECKLIST}

This checklist of ethical considerations is intended to act as the 'conscience' of the conservation professional. It raises questions, but will not necessarily provide

\footnotetext{
${ }^{145}$ Sheila Landi, op.cit., p. 3

${ }^{146}$ Ibidem p. 6.
} 
straightforward answers. Thinking about ethics is not a separate activity and throughout any conservation activity the list should prompt the basic question: 'Am I doing the right thing?' The conservation professional is expected to exercise the judgement gained through training and experience in deciding what is reasonable and accceptable to the profession.

The checklist is applicable to a broad range of conservation activities, not just interventive treatment of individual objects. The whole list should be used before, during and after any action/s; each question is equally valid.

A few definitions are necessary here to avoid confusion and repetition:

Action - any process which the conservation professional may employ and which affects the objects under consideration. These include interventive treatment, preventive conservation measures, examination study, sampling, analysis and doing nothing.

Clients - includes V \& A Curators, other V \& A Departments (including Conservation), the public, students, private owners.

Peers - other conservation professional (conservators, conservators scientists, conservation managers and trainers), other museum and academic professionals (eg curators, art historians, scientists) both internal and external to the $\mathrm{V} \& \mathrm{~A}$.

A background document will be prepared for the Conservation Departamental Library. This will provide a commentary on the checklist and the reasoning behind its present form. It is expected that the list will be revised regularly.

\section{ETHICS CHECKLIST}

A Why is action needed?

B Have I consulted all existing records?

C Do I need to consult any of the following: - clients - peers - other specialists?

D Have I considered all the factors contributing to the identity and significance of the object/s: - historical - technical - associations - sacred - maker's intention?

E What effect will my action/s have on the evidence of these factors?

F Do I have sufficient information and skill to assess and implement action/s?

G What are my options for action which will produce an acceptable result with minimum intervention?

$\mathrm{H} \quad$ What are the advantages and disadvantages of each course of action?

I Can the use or environment be adapted instead of intervening on the objects/s?

J What are the resource implications of my action/s, and is my intended action the best use of resources?

$\mathrm{K} \quad$ Do established courses of action need to be adapted or new ones developed?

L Are all my actions fully documented to a known and accepted standard: - images written - on object/s? 
M Are my records accessible to appropriate users?

$\mathrm{N} \quad$ How will my action/s affect subsequent action/s?

O Have I taken into account the future use and location of the objects/s?

$\mathrm{P} \quad$ How will I assess the sucess of the action/s, and how will I get feedback from clients and peers?

Todo o conteúdo do texto - ao organizar as questões com as quais se deparam os conservadores todas as vezes que decidem intervir sobre um artefato,- poderia ser resumido na questão inicial: Estou fazendo a coisa certa?

Aqui, afinal de contas, o ciclo parece fechar-se outra vez! Retornam as questões colocadas no início deste tópico. Aparentemente todo e qualquer exercício intelectual e ou trabalho aplicado poderá ser considerado ético caso seu autor assim se proponha, posição esta bastante distante da idéia kantiana de imperativo categórico ${ }^{147}$.

O que deduzir ? Os textos citados, excessão feita ao de Hanna Jedrzewska, não só não se preocupam em definir o que seja ético, como enfatizam a importância dos contextos culturais específicos, da formação individual de cada conservador (background) e da prática profissional na construção de critérios e atitude ${ }^{148}$. Talvez devêssemos considerar, mesmo, que a tão difundida ética de nossos dias nada mais signifique que um vento politicamente correto, um exagero fruto mais da propaganda do que das idéias, da inconsistência do que da filosofia. E no Brasil? Será que todo o discurso sobre

${ }^{147} \mathrm{O}$ imperativo categórico de Kant aqui entendido como "o procedimento pelo qual o indivíduo testa a máxima de suas ações para saber em que medida ela é generalizável. Se esta máxima for generalizável, se for suscetível de ser querida por todos, sem contradição interna, poderia aspirar ao estatuto de lei moral universal." Vide Sérgio Paulo Rouanet, Dilemas da Moral Iluminista IN: ÉTICA. São Paulo, Companhia das Letras, 1992, p.150/151.

148 vide Patsy ORLOFSKY;Deborah Lee TRUPIN, The role of connoisseurship in determining the textile conservator's treatment options. Journal of the American Institute for Conservation v.32, n.2, p. 109-118, 1993. 
ética nessa área específica não seria no fundo apenas fruto das poucas opções de profissionalização e da inexistência de um código profissional? E tendo por base os códigos estrangeiros e apoiados em algumas idéias expostas aqui, não seria o caso de nos questionarmos sobre a real necessidade de um código de ética?

Gostaríamos de encerrar este momento da discussão indagando se a atual tendência em se defender a criação de um código de ética brasileiro para área de conservação/restauração, não seria apenas a forma encontrada para legitimar o acesso de alguns mesmos a um mercado restrito de trabalho, numa investida corporativa que resultaria tão somente na rejeição imediata da maioria dos profissionais atuantes, hoje, no país ? Talvez seja melhor refletirmos se realmente precisamos e queremos um código de ética vago e impreciso como tantos outros e deixar claro quais as melhorias este eventualmente traria às nossas práticas profissionais.

\section{O discurso e a prática: alguns estudos de caso.}

Não eram só esses três, pensando bem, talvez. reconhecesse ainda outras fazendas, o filó $e$ o algodãozinho ralo e a chita..... Um paraíso de panos $e$ toques, um paraíso de cores e sensações térmicas $e$ olfativas..... Os panos. Tecido e pano. As fazendas. Tecido como o linho. A seda. Pano, como o algodão. $O$ albene.... a mão sempre poderia correr pelo albene $e$ sentir cada rugosidade, cada passagem de uma fibra a outra, cada intervalo entre uma fibra e outra. ${ }^{149}$

Aparentemente os diversos elementos influentes no trabalho de conservação de têxteis desenvolvido no Museu Paulista da USP já foram

149 Teixeira Coelho e Jean Claude Bernardet, CÉUS DERRETIDOS. São Caetano do Sul, Ateliê Editorial, 1996, p. 152/153. O trecho acima é uma 'montagem' extraída de duas páginas que nunca esqueço e que a cada nova leitura se mostram melhores do que a lembrança que 
sugeridos nesse texto, ainda que brevemente. Tratemos portanto de analisar ou detectar, agora mais detalhadamente, sua influência sobre as intervenções realizadas.

Os estudos de caso que, sem dúvida, compõem mais de $90 \%$ da bibliografia de conservação, costumam ser apresentados quase sempre numa mesma sequiência de tópicos e análise, acompanhados ou não de desenhos, gráficos e fotografias conforme a complexidade do assunto e formato da publicação: livro, resumos de encontros temáticos, etc. Assim estaremos adotando neste texto, em princípio, a costumeira seqüência: descrição, estado de conservação, possibilidades de encaminhamento, procedimento adotado e comentário final. Embora o volume de informações varie consideravelmente em cada caso, todos eles trarão discutida a mesma relação de ítens.

Uma observação todavia precisa ser feita e diz respeito à linguagem adotada. Nesta parte da dissertação procuraremos utilizar uma linguagem intermediária, ou seja, nem leiga nem totalmente específica, considerando-se que este trabalho está sendo apresentado à uma Escola e uma Universidade onde inexistem, ainda, outros especialistas em conservação de têxteis e qualquer curso de especialização em conservação.

\section{Ainda o estrangeiro: dois estudos de caso marcantes.}

Dentre os inúmeros estudos de caso desenvolvidos no estrangeiro e que pudemos acompanhar nesses poucos anos, fosse através da literatura fosse por observação direta ${ }^{150}$, dois deles nos impressionaram profundamente e, com

delas trago comigo. Agradeço a Teixeira Coelho -dentre tantas outras coisas -, ter me ensinado o que é albene (acetato de celulose).

${ }^{150}$ Por observação direta, aqui, chamamos aqueles trabalhos que pudemos acompanhar de perto, em algum instante, ou no The Textile Conservation Centre ou em outro Laboratório estrangeiro por ocasião de uma alguma visita. 
certeza, contribuíram na formação de nossas idéias e indagações profissionais: Spacesuits: NASA's Dream-Conservator's Nightmare da autoria de dois profissionais da Smithsonian Institution e The Conservation of $\mathrm{Mr}$ Merrick's hat, projeto final de curso da profissional inglesa Michelle Harper. ${ }^{151}$

O primeiro estudo de caso apresenta as dificuldades encontradas na conservação de uma coleção única no planeta. Desde 1967 um acordo entre a NASA e o National Air and Space Museum em Washington previu o envio ao museu de todo o equipamento espacial fora de uso. A primeira dificuldade encontrada por curadores e conservadores foi conseguir que os modelos de trajes espaciais projetados e posteriormente rejeitados por questões técnicas, não fossem destruídos: "While the changes can be followed by examination of the flown suits, this does not tell the whole story. Many ideas and improvements were tested on prototype suits; some of these changes were adopted for the final suits; others were not. Some were of a completely different design...A collection of only the suits used on missions does not give a complete story of the inventiveness that went into suit design. (...) considering the amount of records that have been destroyed by NASA and the suit manufacturers, these non-mission suits may be the only record of the course of these developments." 152

A maior parte do estudo, todavia, dedica-se à discussão das dificuldades em estabilizar os materiais que compõem os trajes, materiais esses que variaram muito desde o início do programa espacial americano.

\footnotetext{
${ }^{151}$ Mary T. Baker e Ed MacManus Spacesuits: NASA's Dream-Conservator's Nightmare IN: SAVING THE TWENTIETH CENTURY: THE CONSERVATION OF MODERN MATERIALS. Ottawa, Canadian Conservation Institute, 1993, p. 223-230. e Michelle Harper - THE CONSERVATION OF MR. MERRICK'S HAT. London, 1995. Diploma Report - The Textile Conservation Centre/Courtauld Institute of Arts - University of London.

${ }^{152}$ Mary T. Baker, op. cit. p. 224 e 228
} 
$\mathrm{O}$ segundo estudo de caso mostra o trabalho realizado com o chapéu/máscara do Sr. Merrick, mundialmente conhecido como o HomemElefante. O objeto - que pudemos observar antes do trabalho de intervençãofoi utilizado pelo Sr. Merrick todo o tempo e por toda sua vida. Trata-se de um objeto de difícil descrição: quase um saco, enorme e disforme, a indicar as proporções físicas do Sr. Merrick: algo que não se esquece e que de imediato invoca compaixão no observador. Por nunca retirá-lo (a justiça inglesa o proibia), mesmo durante sua alimentação, o chapéu/máscara adquiriu uma série grande de marcas, manchas de toda a natureza e conservava, internamente, uma série de detritos de alimentos aderidos à sua extremidade frontal inferior. O ponto central do trabalho, portanto, foi a discussão de quais evidências deveriam ser preservadas.

Os dois casos, como mencionamos, propuseram discussões bastante significativas. O primeiro estudo nos pareceu especial nos seguintes pontos:

1. os objetos são extraordinários;

2. são objetos cuja preservação é e será sempre um desafio;

3. são objetos importantes, no sentido expresso na introdução deste trabalho.

Já o segundo estudo apontou questões de outra natureza. Nele quase todas as colocações apresentadas anteriormente nesta dissertação poderiam ser encontradas: preceitos éticos, intervenção mínima, exagero (da natureza e da sociedade), bem como todas as atitudes e posturas profissionais politicamente corretas. Cabe esclarecer que o chapéu/máscara do Sr Merrick - oficialmente declarado de interesse médico, - foi mantido quase como se encontrava, incluindo-se nessa condição a manutenção dos detritos de alimentos na parte interna!

Talvez esses dois casos sejam realmente extremos e pouco comuns, mas são exemplos de trabalhos que andam sendo feitos mundo afora, e que junto com 
mortalhas, múmias e outros objetos inusitados, integram a área de conservação de têxteis.

\section{Os estudos de caso do Museu Paulista/USP .}

Procuramos escolher o mais objetivamente possível alguns casos que propuseram, de diversos modos, questões e/ou soluções bastante diferenciadas umas das outras durante o desenvolvimento dos trabalhos. Além dos ítens geralmente discutidos na apresentação de estudos de caso, conforme já mencionado anteriormente, acrescentamos ao final de cada relato o ítem "analisando o que foi feito" no qual comentamos o trabalho executado a partir das considerações levantadas durante os capítulos precedentes.

\section{Estudo de caso 1:}

\section{A CONSERVAÇÃO DE UMA BANDEIRA DO CONTESTADO ${ }^{153}$.}

Vista geral da bandeira já em exposição.

\section{descrição}

Bandeira retangular (irregular) em tecido de algodão sem tingimento (pano/tela 1/1), com grande cruz em seda cinza/azulada (?) costurada com fio celulósico, sobre a qual se encontra costurada uma pequena medalha de metal. Suas medidas máximas são 74 x 92,5 cm.

\section{estado de conservação}

Bom $^{154}$. Apresentava marcas de dobra, mancha d'água na lateral superior direita, manchas causadas por óxido de ferro na lateral direita, detritos de insetos e

\footnotetext{
${ }^{153}$ coleção Museu Paulista, RG 3603. Foto José Rosael.
} 
pequenas áreas com perda de suporte $(0,5 \%)^{155}$ nas extremidades inferior e superior e no centro esquerdo. A cruz encontrava-se em bom estado com as cores originais (vermelho, amarelo, cinza e azul ?) esmaecidas. A medalha em metal não apresentava oxidação.

\section{possibilidades de encaminhamento}

A Bandeira foi encaminhada para conservação a fim de ser preparada para integrar exposição temporária em novo espaço expositivo, no sub-solo do museu.

Questões a serem resolvidas:

1. método de hidratação das fibras e subseqüente eliminação de marcas, vincos e distorções causadas pela condição inadequada de armazenagem. A presença de duas fibras de características e comportamento bastante diferenciados como a seda e o algodão somada à presença da medalha em metal, tiveram que ser consideradas;

2. o modo como a bandeira seria exposta: o espaço disponível exigia a verticalidade quase total do objeto e portanto era imperativa a opção por uma base em material e forração que, por abrasão ${ }^{156}$, contivesse os efeitos da gravidade;

${ }^{154}$ o estado de conservação de um objeto - no Setor de Conservação de Têxteis - pode ser descrito de quatro modos: bom, regular, mau e péssimo. Resumidamente, entende-se como: bom: objetos que não apresentam problemas estruturais; regular: objetos que apresentam certos problemas estruturais que podem ser revertidos como distorções, alguma perda de suporte e outros problemas como manchas, rasgos ou outros, se for o caso, sem entretanto terem suas estruturas físicas comprometidas; mau: objetos cuja estrutura física já foi comprometida por qualquer das razões citadas e que demandam, necessariamente, um trabalho mais intervencionista; péssimo: objetos em avançado processo de degradação.

155 do mesmo modo, as perdas de suporte são indicadas quantitativamente, de 0,5 a $100 \%$, considerando-se a extensão/proporção da área faltante em relação à extensão.

${ }^{156}$ sobre o efeito abrasivo de alguns tecidos de algodão utilizados para suporte vide: Loern Palmer Simpson. Abrasiveness of certain backing fabrics for supporting historic textiles. Journal of the American Institute for Conservation, n.30, p. 179-185, 1991. 
3. a forma como o objeto seria 'preso' ao suporte.

\section{procedimento adotado}

1. A Bandeira foi submetida a várias seções de umidificação com vapor frio, através de umidificador ultrasônico (CLE) por períodos diários de 2 minutos, aproximadamente, durante três semanas. Numa primeira fase o objeto foi trabalhado na horizontal e a movimentação das fibras foi induzida por pequenos

pesos de polietileno expandido, tipo ETHAFOAM ${ }^{\circledR}{ }^{157}$. Posteriormente a bandeira foi trabalhada em posição inclinada sobre suporte do mesmo material. Durante todo o processo a medalha em metal esteve envolvida por filme de polietileno. Pequenas sujidades foram removidas mecanicamente com bisturi.

2. Optou-se pela construção de um suporte feito por uma prancha de ETHAFOAM ® com $3 \mathrm{~cm}$ de espessura, coberta com malha tubular de algodão ORTOFEN $®, 30 \mathrm{~cm}$.

3. A posição quase totalmente vertical em que a bandeira seria exposta impunha que ela fosse 'presa' ao suporte, já que a abrasão fornecida pela malha de algodão não garantiria, a longo prazo, a estabilidade do objeto. Construiu-se então uma faixa de tecido de algodão não alvejado, de aproximadamente 7 x 70 $\mathrm{cm}$ e sobre ela se aplicou, com costura, uma faixa de VELCRO ® de 5,5cm de largura e mesma extensão. A faixa pronta foi então costurada à Bandeira, no verso, extremidade superior, com fio de poliéster bege, em duas linhas paralelas de ponto reto, sentido Oeste/Leste. O suporte, por sua vez, recebeu a outra metade do VELCRO ${ }^{\circledR}$ e assim a Bandeira pôde ser 'fixada' à base com total segurança. 


\section{comentário final}

Todos os objetivos da intervenção foram alcançados. Houve uma melhora das condições estruturais e visuais do objeto e a opção na escolha do suporte e na forma de sustentação da Bandeira corresponderam ao esperado.

\section{analisando o que foi feito}

No caso apresentado ficaram evidentes:

- a opção pela intervenção mínima já que sequer foi cogitada a hipótese de lavagem (aquosa ou não) o que, dentre outros fatores, implicaria na remoção temporária da medalha e perda das costuras e fios originais. Ao mesmo tempo a necessidade de introduzir, por costura, uma faixa em tecido no verso da bandeira, já foi considerada uma intervenção bastante grande!

- a atitude politicamente correta, já que a hipótese de remover manchas e outras 'marcas' nos pareceu injustificada para um objeto manufaturado para ser utilizado em combate, apenas.

- o citado 'apaixonamento' pelo objeto aconteceu. A bandeira, aparentemente feita de tecidos reaproveitados (a seda, da qual a cruz foi feita, é muito delicada e foi tecida com uma grande variedade de fios em tons e degradês, contrastando totalmente com a rudez do algodão), não apresenta nenhuma preocupação com as proporções e linhas retas. É um objeto belíssimo, único talvez. O objeto nos remeteu - além do necessário - a uma série de leituras sobre o movimento do Contestado.

${ }^{157}$ ETHAFOAM $®$ é o nome comercial do polietileno expandido comercializado pela DOW Química. Todavia, assim como o termo ISOPOR - produto da BASF -, o nome passou a ser associado mundialmente a uma forma determinada de polietileno expandido. 


\section{Estudo de caso 2:}

\section{A CONSERVAÇÃO DE UM PEITORAL BANDEIRANTE DO SÉCULO XVII. ${ }^{158}$}

Vista das partes do peitoral tal qual se encontram expostas hoje.

\section{descrição}

Peitoral (colete) com duas partes independentes, feitas em tecido celulósico pintado na cor uva e sobre o qual foram costuradas inúmeras partes metálicas (ferro?) em forma de escamas, que foram igualmente pintadas de 'bronze'. As laterais apresentam fechamentos metálicos, complementares uns aos outros. A parte frontal apresenta uma malha metálica em sua parte superior . Note-se que ambas as partes são bastante pesadas.

\section{estado de conservação}

Mau. As partes foram retiradas da exposição permanente e trazidas ao atelier apenas para que um novo suporte fosse preparado. Até então acreditava-se que ambas fossem dois objetos distintos, conforme constava de sua documentação. Apenas durante os trabalhos de conservação é que ficou constatado tratar-se de um único objeto, anverso e verso. As partes- devido ao seu peso e por terem ficado expostas com pouca inclinação, em suportes menores que suas dimensões sugeriam, - apresentavam uma série de problemas. Do mesmo modo, apenas após vários exames é que foi possível constatar que o peitoral havia sido totalmente 'refeito' por um profissional alemão que realizara uma série de 'restaurações' em objetos do museu. Apesar de inexistirem registros sobre os procedimentos adotados foi possível deduzir o seguinte:

- as partes foram totalmente desmontadas, com a remoção das escamas metálicas;

\footnotetext{
${ }^{158}$ coleção Museu Paulista, RG 1163 e 1164 . Foto José Rosael.
} 
- o tecido de ambas as partes, provavelmente sujo e de mau aspecto foram pintados com tinta a base d'água, na cor uva;

- as escamas metálicas, por apresentarem um processo de oxidação avançado, foram pintadas com tinta em cor que imita o bronze;

- as escamas foram redistribuídas, nas duas partes, de modo a 'disfarçar' as lacunas derivadas da perda de várias unidades;

- no lado interno das partes, sobre o tecido, foram colados (com cola animal ?) três pedaços de VELCRO ${ }^{\circledR}$ com o objetivo de 'segurar' os coletes no suporte de exposição.

Quando encaminhado à Conservação de Têxteis, o objeto apresentava os seguintes problemas aparentes:

- fortes distorções causadas pelo peso e o suporte inadeqüado;

- várias partes metálicas encontravam-se soltas;

- as partes se encontravam muito sujas.

\section{possibilidades de encaminhamento}

$\mathrm{O}$ objeto precisava retornar à exposição permanente em novo suporte. $\mathrm{O}$ peitoral pertence a um grupo de objetos 'preferidos' pelos visitantes do museu! opção 1:

documentação da situação atual, limpeza, fixação das escamas soltas e elaboração de um suporte adeqüado do ponto de vista conservativo e histórico, já que era necessário informar ao público que as partes constituíam um único e mesmo objeto.

opção 2:

-documentação da situação atual;

- remoção de todas as escamas e da pintura aplicada sobre elas; 
-estabilização do processo de corrosão do metal por um profissional especializado.

- tentativa de remover a pintura do tecido através de lavagem, caso as análises realizadas por microscópio de varredura assim o indicassem;

- remontagem completa;

questões a serem ponderadas:

- o objeto na situação em que se encontrava era um fake ${ }^{159}$ (na verdade, dois), um documento falso, sendo exibido por um museu histórico, universitário, que se propõe em regimento a educar e esclarecer seus visitantes sobre a natureza dos processos históricos e sócio-culturais de nossa sociedade;

- caso a opção 2 fosse adotada, deixaria ele de ser um fake ? Por quê? Existiria, ainda, um original a ser recuperado?

-se aquele original não mais existia, não seria mais fácil construir-se uma cópia?

- mas será que um fake, nos termos citados, não se torna ele próprio um documento ?

\section{procedimento adotado}

1.Foi adotada a primeira opção aqui descrita.

2. As partes do peitoral foram detalhadamente documentadas. Foi feito um mapeamento das escamas metálicas já faltantes por ocasião da intervenção anterior e daquelas faltantes posteriormente.

3. As tiras de VELCRO ${ }^{\circledR}$ foram removidas mecanicamente, mas parte do adesivo permaneceu aderido ao suporte.

${ }^{159}$ Em 1990 o British Museum, Londres, organizou a mostra Fake? The art of deception acompanhada de um seminário e posterior publicação, onde se encontram discussões sobre o falso, a imitação, a cópia, etc. vide: M. Jones, FAKE? THE ART OF DECEPTION . London, The British Museum, 1990. 
4. As escamas foram limpas mecanicamente com swob em solução $50 \%$ etanol $\mathrm{C}_{2} \mathrm{H} 5 \mathrm{OH}, 50 \%$ metanol $\mathrm{CH} 3 \mathrm{OH}$.

5. As escamas soltas foram amarradas às contíguas com fio de poliéster marrom.

6. Foram elaborados dois suportes em madeira, horizontais, excedendo as dimensões dos peitorais em $2 \mathrm{~cm}$, aproximadamente. A madeira foi recoberta com folhas de alumínio (do tipo usado em cozinha) a fim de evitar futuros $\operatorname{danos}^{160}$, recebendo em seguida uma camada de manta acrílica e o acabamento externo em malha de algodão. Entre os peitorais e a base foi colocado, ainda, um tule sintético para evitar o contato direto base/verso.

7. As partes retornaram à exposição permanente em posição que sugere serem um só objeto.

\section{comentário final}

Houve uma melhora nas condições de exposição do objeto. Ele se encontra em observação dado que o problema de decomposição do metal não foi abordado. O texto explicativo que o acompanha - falando em dois peitorais- ainda não foi substituído. Este objeto foi conservado em março/maio de 1995.

\section{analisando o que foi feito}

O caso apresentado é um exemplo interessante de como museu e a atividade de conservação/restauração podem 'forjar' um documento e a 'construção do passado', questão esta que extrapola os limites deste ensaio.

\footnotetext{
${ }^{160}$ A madeira, do ponto de vista da conservação, é inconveniente a todas as tipologias de acervo; propaga ácidos e formaldeído, metanal, um gás bastante daninho a médio e longo prazos. Vide: CARPENTER, Jane; HATCHFIELD, Pamela. The problem of formaldehyde in Museum Collections. In: TEXTILE TREATMENTS REVISITED. Washington: Washington National Museum of American History/Smithsonian Institution, 1986. p. 35-39.
} 
O encaminhamento adotado, entretanto, evidenciou a opção pela intervenção mínima, embora nesse caso ela tenha sido adotada a partir do pressuposto de que restaram poucos elementos 'autênticos' a serem preservados. Mencione-se, aqui, nosso desconforto permanente com a exposição de um objeto com tais características.

\title{
Estudo de caso 3:
}

\section{A CONSERVAÇÃO DE UMA BONECA DA DÉCADA DE $1920 .{ }^{161}$}

\author{
Boneca e roupas já em exposição.
}

\section{descrição}

Boneca em massa de papelão pintada com cabeça de porcelana, olhos de vidro e cabelos de fios de seda, provavelmente alemã. Roupas: vestido de algodão em renda filé e forro de seda; anágua em algodão com bordado e renda de bilro; sapato de linha de algodão tricotada e solado em tecido de seda.

\section{estado de conservação}

Regular. A boneca foi encaminhada para conservação sob suspeita de infestação por brocas, o que posteriormente foi confirmado. Encontrava-se separada em 06 partes: cabeça, corpo e braços, coxa esquerda, coxa direita, parte inferior da perna esquerda com pé e 'joelho'(articulação da perna); faltavam-lhe a parte inferior da perna direita com pé e o 'joelho' direito. A boneca, antes de ser doada ao museu, já sofrera algumas intervenções. $O$ rosto apresentava repinturas, a cabeça/cabelo já haviam sido 'restaurados' e o restante do corpo também havia recebido pintura e a aplicação de 'verniz'. As roupas, encaminhadas muito tempo depois, apresentavam apenas alguns vincos e dobras decorrentes da situação de armazenagem.

\footnotetext{
${ }^{161}$ coleção Museu Paulista, RG 7286. Roupas: RG 7287, 7289 e 7295a. Foto José Rosael.
} 


\section{possibilidades de encaminhamento.}

Este objeto foi trabalhado em dois momentos distintos, num intervalo de três anos.

1. Primeiramente- como sempre ocorre nesses casos, - a boneca foi encaminhada à conservação por apresentar suspeita de infestação, tendo permanecido sob observação constante até o segundo momento, recente, quando foi trabalhada para integrar uma nova exposição do museu. Nessa primeira etapa havia necessidade de confirmar a infestação e decidir como eliminá-la sem prejuízo dos materiais. A principal decisão a ser tomada dizia respeito a utilização ou não de produtos químicos, residuais.

2. Na segunda fase, da montagem da boneca, havia duas possibilidades básicas:

- remontagem completa da boneca, com a substituição dos cordões internos-já sem tração, - por cordões novos o que em tese deveria ser realizado por um especialista;

-remontagem da boneca através de um sistema alternativo a ser pesquisado.

\section{procedimento adotado}

1. As partes da boneca foram limpas (com aspiração visando a remoção dos depósitos deixados pelos insetos) e colocadas, separadamente, em embalagens de polietileno de baixa densidade, com fecho hermético, FREEZER $®$, de uso doméstico. O objetivo era identificar em quais partes havia infestação. Foram localizados dois insetos que puderam ser mortos mecanicamente.

2. A cada período de 30 dias as embalagens eram checadas para verificar se persistia alguma atividade, o que foi constatado mais duas vezes. Optou-se pela não utilização de produtos químicos. 
3. A montagem da boneca foi realizada sem a substituição do cordoamento original. As pernas e a cabeça foram ligadas ao corpo central com a introdução de dois fios de pescaria de nylon e arame (nylon coated wire leader) EXORIFISHINGS ®, através das cavidades disponíveis. Para dar sustentação aos braços e juntas foi confeccionada uma 'camiseta' de mangas longas, em malha de algodão, costurada no verso.

4. As roupas receberam duas seções de umidificação com vapor frio, através de umidificador ultrasônico (CLE) por períodos diários de 2 minutos, aproximadamente.

5. A fim de garantir a estabilidade da boneca, comprometida pela perna faltante, foi 'esculpida' uma base em ETHAFOAM ® posteriormente recoberta com malha tubular de algodão ORTOFEN $®, 30 \mathrm{~cm}$. O suporte foi produzido de forma a possibilitar que a boneca, sentada, ficasse encaixada na base.

\section{comentário final}

Mesmo em exposição a boneca continua em observação constante. Tudo indica que tanto a estrutura interna (malha) quanto a base produzida estão garantindo a segurança e sustentação necessárias às partes.

\section{analisando o que foi feito}

Neste trabalho podemos apontar o següinte:

- a opção pela não utilização de produtos químicos, a adoção da alternativa 'natural'. Aqui, sem dúvida, encontramos uma opção pessoal, de contexto, mas reflexo desses tempos. Parece pouco lógico utilizarmos produtos químicos para conservar algo e com isto destruir algo outro: a quase totalidade dos laboratórios de conservação do país não está aparelhada para lidar com produtos químicos de forma responsável. Alguns avanços foram feitos no que diz respeito à saúde do profissional, mas quase nada existe (nem mesmo a 
consciência disso) com respeito à emissão desses produtos ao meio ambiente, seja no ar seja no sistema hidráulico.

-a idéia da reversibilidade, do less is more, também é evidente. A remontagem da boneca foi toda realizada sem 'interferência' ou alteração física das partes. Aparentemente tudo que lá está poderá ser removido oportunamente caso se faça necessário.

-os brinquedos, de modo geral, são objetos bastante prazerosos de serem trabalhados. O sentimento despertado não é o do apaixonamento, nos termos anteriormente apresentados, mas é igualmente agradável e especialmente sugestivo.

\section{Estudo de caso 4:}

\section{A CONSERVAÇÃO DE TRÊS QUÉPIS E TRÊS BONÉS DA GUARDA NACIONAL ${ }^{162}$.}

Quépi ainda distorcido, já em seu suporte permanente de armazenagem.

\section{descrição}

Todas as coberturas de cabeça apresentam estrutura e confecção similares, destacando-se o fato dos bonés trazerem jugulares. As copas são moldadas em papelão sobre o qual é aplicado um feltro ou tecido de lã. As palas são de couro ou material sintético e os bordados, botões e outros ornamentos, geralmente em metal dourado e tecido.

\section{estado de conservação}

Os problemas de conservação verificados nos seis objetos eram bastante semelhantes. Esta tipologia de objeto tende a deformar quando armazenada sem suporte adequado: o peso do topo da copa somado ao efeito da gravidade faz 
com que ela apresente um efeito 'sanfona' que além de causar dobras, vincos e penças, provoca a distorção da pala e laterais inferiores. Além desses problemas verificaram-se perdas do tecido causadas por insetos (nunca superiores a 5\%) e, internamente, várias áreas apresentavam perda da costura além de etiquetas adesivas aderidas à forração.

\section{possibilidades de encaminhamento}

A abordagem dos objetos apresentava problemas. De imediato foi necessário providenciar-lhes suportes individuais, elevando-os um pouco e com isso evitando que as áreas inferiores e palas permanecessem em situação de stress. A solução permanente desse problema era a principal dificuldade a ser enfrentada. Era necessário projetar suportes que garantissem a estabilidade das formas. Mas como fazê-los com os objetos distorcidos? Uma primeira opção seria tratá-los a longo prazo até que todas as distorções tivessem desaparecido. Outra opção seria induzir e acelerar a movimentação dos materiais, operação de risco que poderia ocasionar rupturas nos materiais e fibras. Uma terceira opção seria criar um método alternativo que garantisse o efeito desejado a médio e longo prazos, sem que contudo o objeto tivesse que permanecer 'em tratamento'.

\section{procedimento adotado}

1. Após receberem um suporte provisório- feito com manta acrílica e malha de algodão, - as coberturas foram limpas com aspiração e trincha.

2. Para limpeza da parte interna foi providenciado outro suporte de sustentação. As etiquetas adesivas foram removidas mecanicamente com bisturi após aplicação localizada de CMC (carboxy-metil-celulose).

\footnotetext{
${ }^{162}$ Coleção Museu Paulista. Quépis RG 1055, RG 1058, RG 1059. Bonés RG 1056, RG 1056a, RG 1057. Reprodução de slide
} 
3. Os suportes foram construídos com manta acrílica e malha de algodão nas proporções e alturas necessárias a cada caso. A idéia básica foi construí-los um pouco menores em largura, de modo a assegurar que os chapéus, sozinhos, mediante a ação da gravidade a médio prazo, fossem se abrindo novamente com segurança total. Do mesmo modo a altura e angulo dos suportes para as palas precisaram ser calculados para que a movimentação pretendida pudesse ocorrer sem prejuízo das extremidades.

4. As unidades que apresentavam perda da forração interna receberam proteção com tule sintético a fim de evitar eventuais problemas nas áreas em papelão.

5. Estes suportes, por sua vez, foram presos a uma base retangular de espuma de borracha, dado que naquele tempo não havia ETHAFOAM ${ }^{\circledR}$ disponível no mercado brasileiro. A base foi coberta com tecido de algodão não alvejado, aberto em uma das laterais, já prevendo a futura substituição do material.

6. Algumas coberturas apresentavam emblemas ou insígnias desprendidas. Devido ao seu peso não foram recolocadas e sim 'presas' à base por um 'sanduíche' de tule sintético.

7. As unidades que apresentavam jugulares receberam proteção especial nessas áreas, evitando que o couro e/ou metal que as compõem viessem a danificar o tecido por abrasão.

\section{comentário final}

O movimento descendente das coberturas foi acompanhado nos dois anos subseqüentes não tendo sido constatado nenhum problema. As distorções foram corrigidas e as coberturas encontram-se, hoje, em suas formas e dimensões naturais.

\section{analisando o que foi feito}


Neste caso, em especial, dois pontos merecem ser destacados:

- a idéia de preservação como um processo contínuo de trabalho seja a médio seja a longo prazos. Não só se optou por um processo 'natural' de reversão de um problema estrutural, como também projetaram-se embalagens visando sua futura substituição por um material estável ainda não disponível no mercado local.

- a criação de uma alternativa diferenciada para a solução de um problema determinado é uma característica da área de conservação de têxteis: são muitas as tipologias de objetos e múltiplas as suas formas. Daí, acreditamos, o grande fascínio dessa área sobre as outras especialidades. Note-se mais uma vez que as idéias de reversibilidade e interferência mínima permearam todo o trabalho.

\section{Estudo de caso 5:}

\section{A CONSERVAÇÃO DE UM VESTIDO DA MARQUESA DE SANTOS $^{163}$.}

Vista geral do vestido antes dos trabalhos de conservação

\section{descrição}

Vestido longo e mangas curtas, em seda, originalmente 'branca', bordado com fios de prata em motivos florais nas mangas e em toda a volta da saia, desde a altura dos joelhos até a extremidade inferior (aproximadamente $30 \mathrm{~cm}$ ). Nesta área, internamente, há uma forração de tecido celulósico, provavelmente algodão.

\section{estado de conservação}

Regular/Mau. O vestido encontrava-se bastante deteriorado não podendo sequer ser manipulado para documentação. Encontrava-se dobrado em 04 partes. A seda, heavy silk, encontrava-se quebradiça devido a sua composição e os fios

\footnotetext{
$\overline{{ }^{163} \text { Coleção Museu Paulista RG } 1210}$
} 
metálicos oxidados. A parte superior da peça, até a cintura, e a área inferior com bordado estavam em melhor estado de conservação. A parte mais prejudicada do vestido era a saia. Sabe-se que o vestido esteve em exposição por décadas, sem proteção especial, daí os danos verificados na saia pelo peso dos bordados. Havia rasgos verticais em muitas áreas, partes soltas e embaralhadas e foram encontrados alguns reparos anteriores nessa região e na área junto aos ombros. Os bordados (fios), de modo geral, encontravam-se enrijecidos e bastante vincados.

\section{possibilidades de encaminhamento}

O vestido precisava ser 'aberto' para ser fotografado e documentado. Havia duas possibilidades básicas de abordagem:

1. processo completo de intervenção. Com ele o vestido voltaria a apresentar a sua forma de origem, podendo ser exposto. Seria um processo de longa duração e, provavelmente, seria necessária a utilização de adesivos na região da saia, o que por sua vez implicaria em:

- perda da mobilidade do tecido;

-irreversibilidade total do processo;

-eventual surgimento de manchas e escurecimento da região que iria receber o adesivo, visto inexistirem testes e literatura sobre o comportamento desses materiais em climas sub-tropicais e temperados;

- o museu não oferecia condições satisfatórias de armazenagem que garantissem a futura boa condição do objeto.

2. processo parcial de conservação. Com ele o objeto seria limpo, protegido, teria seu acesso viabilizado, mas não poderia ser exposto. Nessa situação o vestido aguardaria, em segurança, por uma intervenção futura em momento mais oportuno. 


\section{procedimento adotado}

1. Foi escolhida a segunda abordagem. O vestido ainda dobrado foi colocado sobre uma grande mesa forrada com plástico. Gradualmente, com o auxílio de vários suportes feitos de manta acrílica e malha de algodão (como travesseiros), o vestido foi sendo desdobrado e as partes sustentadas de forma a facilitar o relaxamento das fibras. A duração dessa etapa foi de aproximadamente três meses.

2. Grande quantidade de sujidade superficial foi removida mecanicamente.

3. Construiu-se um suporte interno em manta acrílica e malha de algodão, dividido em duas partes - blusa e saia,- nas formas do vestido, com aproximadamente $10 \mathrm{~cm}$ de altura.

4. O suporte foi introduzido no vestido e a partir de então as partes foram acomodadas sobre ele. Várias áreas com dobras, no verso principalmente, foram sustentadas com pequenas almofadas.

5. O vestido com a estrutura recebeu um 'sanduíche' de tule sintético que foi costurado nas laterais e no suporte interno nas áreas vazadas por perdas do tecido original.

6. Devido a suas dimensões, principalmente na largura, o vestido precisou ser enrolado na embalagem que o guardaria.

7. Foi confeccionada uma caixa de madeira, com laterais que se abrem e alças nas partes superior e inferior.

8. Um grande tecido de algodão não alvejado forrava a caixa: o vestido foi colocado sobre a caixa com as laterais abertas. Um rolo de manta acrílica e malha de algodão de aproximadamente $30 \mathrm{~cm}$ de diâmetro foi colocado sobre a saia do vestido e sobre ele foram 'enroladas' as laterais da saia. Dois pares de faixas de tecido, presas ao tule, amarraram toda a estrutura. 
9. O mesmo tecido de algodão foi utilizado para cobrir o vestido e a caixa foi fechada nas laterais.

\section{comentário final}

A estrutura desenvolvida permite acesso seguro ao vestido. Basta colocar-se a caixa sobre uma mesa, abrirem-se suas laterais e se desamarrarem as faixas para que o vestido esteja 'completo', embora na horizontal e cheio de proteções. Os objetivos pretendidos com essa intervenção foram atingidos de forma satisfatória, podendo o objeto permanecer nessa condição por tempo indeterminado.

\section{analisando o que foi feito}

A opção de trabalho escolhida- além de mais uma vez evidenciar a atitude politicamente correta, cientifizada, ética - de não interferir sobre um objeto quando não há garantia quase total sobre o que será realizado, - exemplifica também uma política de gestão na conservação dos objetos têxteis. O vestido da Marquesa de Santos, assim como uma dezena de outros objetos, pertencia à fração dos 'grandes problemas' da coleção, ou seja: um grupo de objetos que não podiam sequer ser manipulados dada sua condição de fragilidade. Outra característica dessas unidades de acervo, conseqüentemente, era demandarem um trabalho completo de intervenção que, dentre várias outras coisas, exigiria um investimento muito grande de tempo e atenção exclusiva. Naquele momento institucional, como ainda hoje, não há sentido em se despender um longo período de tempo na conservação de um único objeto enquanto coleções inteiras necessitam cuidados. Uma intervenção como essa, em nosso entendimento, simplesmente não é prioritária, não se justifica. Futuramente quando todo o acervo já tiver recebido cuidados elementares, e caso seja considerado importante, o objeto poderá ser recuperado em forma e estrutura. 
Cabe acrescentar que objetos como esse vestido não despertam nenhum sentimento especial. A motivação, nesses casos, é dada pelo desafio de buscarse uma solução adeqüada, de acreditar que se é capaz de enfrentar o problema de forma minimamente satisfatória.

\title{
Estudo de caso 6:
}

\section{A CONSERVAÇÃO DE UMA CAMISA DO PRESIDENTE PARAGUAIO SOLANO LOPEZ. ${ }^{164}$}

\author{
Vista geral da camisa já em exposição
}

\section{descrição}

Camisa de mangas longas e gola curta dobrada, em cambraia de algodão branco (pano/tela 1/1), bordada a mão no anverso central e punhos, com abotoamento frontal de madrepérolas.

\section{estado de conservação}

Regular. A camisa encontrava-se bastante escurecida (oxidação) em 95\% de sua área. Encontrava-se muito vincada e com marcas fortes de dobradura. Foram localizados pequenos furos no anverso, na região junto ao bordado. Na parte interna inferior do verso havia uma etiqueta em papel aderida ao tecido.

\footnotetext{
${ }^{164}$ Coleção Museu Paulista RG 3606. Foto José Rosael.
} 


\section{possibilidades de encaminhamento}

O objeto foi encaminhado para conservação a fim de ser preparado para integrar exposição temporária em novo espaço expositivo, no sub-solo do museu. Tal qual a bandeira do Contestado aqui citada, seria necessário:

1. descobrir a forma como a camisa seria exposta já que o pouco espaço disponível exigia que o objeto fosse exposto em quase total verticalidade. Diferentemente da bandeira, um tecido bidimensional, a camisa exigia um formato que lhe desse suporte e leitura.

2. Definir o modo de hidratação das fibras e eliminação dos vincos e marcas de dobradura.

\section{procedimento adotado}

1. A camisa foi submetida a três seções de umidificação com vapor frio, através de umidificador ultrasônico (CLE) por períodos diários de 2 minutos, aproximadamente.

2. Como aparentemente as fibras pareciam não reagir a umidificação, levantou-se a hipótese do tecido ser feito de linho e não de algodão como constava na documentação. A observação, mesmo magnificada em 10 vezes, não oferecia definição. Um especialista da Escola SENAI têxtil Francisco Matarazzo compareceu ao museu e confirmou a situação de dúvida. Assim foi retirado um fio (aproximadamente $01 \mathrm{~cm}$ de comprimento) como amostra e enviado à microscopia.

3. O resultado indicou que o tecido era mesmo de algodão (CO). As microfotografias sugeriram, entretanto, que o tecido fora produzido com algodão mal formado, verde ou morto. As fibras aparentavam ter sofrido enorme desgaste por um excesso de ação mecânica e secagem, o que teria ocasionado uma perda radical da umidade e de suas características principais. O resultado explicava, 
assim, a não reação das fibras à umidificação aplicada e a textura 'dura', mais próxima do linho do que do algodão.

4. As seções de umidificação tiveram sua duração estendida a 4 minutos e foram realizadas duas vezes ao dia, durante três dias. Em seguida foram realizadas novas seções de 2 minutos, durante quatro dias. As primeiras seções foram realizadas com o objeto na horizontal e as seguintes com ele em plano inclinado.

5. A etiqueta adesiva foi removida mecanicamente durante uma das seções de umidificação.

6. Optou-se pelo construção de um suporte feito por uma prancha de ETHAFOAM ® com $3 \mathrm{~cm}$ de espessura, coberta com malha tubular de algodão ORTOFEN ®, $30 \mathrm{~cm}$. A parte superior da prancha foi recortada de modo a preencher as linhas e o volume do pescoço e ombros. Com o recorte nas dimensões apropriadas não foi preciso acrescentar nenhum outro material de sustentação.

6. Nos punhos foram colocados dois suportes confeccionados em papel poliéster cristal, gramatura 0,3 da RHODIA $^{165}$, recobertos com malha tubular de algodão ORTOFEN ®, $04 \mathrm{~cm}$ depois costurados em forma circular.

7. O suporte não precisou de nenhum acréscimo na vitrine, apoiando-se embaixo sobre sua própria área - alguns centímetros mais alta que a camisa, - e na extremidade do 'pescoço' em sua região superior .

8. Os furos foram desconsiderados por não apresentarem riscos à tecedura.

\section{comentário final}

As ações desenvolvidas mostraram-se eficientes em melhorar as condições estruturais do objeto ficando evidente a importância da microanálise em situações em que haja dúvidas na identificação dos materiais.

\footnotetext{
${ }^{165}$ Este material é normalmente conhecido como 'acetato'.
} 


\section{analisando o que foi feito}

Esse objeto foi bastante interessante de ser trabalhado. Subjetivamente ele já apontava um contraste curioso: pertencera a uma figura histórica controversa e no entanto apresentava um corte e bordados de uma sutileza extrema, a indicar que seu proprietário fora um homem de bom gosto. Objetivamente, as informações trazidas pela microscopia nos surpreenderam. Trata-se de um objeto exaustivamente usado, submetido a inúmeras lavagens e secagens diferentemente do que sua boa condição estrutural visível e seu proprietário poderiam sugerir. Cabe aqui relatarmos uma informação não registrada que nos foi revelada por uma pesquisadora já aposentada do museu. Por ocasião da doação da peça, foram entregues ao museu duas camisas de Solano Lopez: a examinada neste texto e outra, toda rasgada, suja de sangue e cheirando mal que foi imediatamente descartada e desconsiderada como documento, já que poderia 'contaminar' outras unidades do acervo com suas bactérias.

A partir do ponto de vista do procedimento politicamente correto de hoje em dia custa-nos a crer que isso realmente tenha ocorrido. Entretanto trata-se de uma prática comum à maioria dos museus históricos brasileiros e deve sempre ser comentada levando-se em conta um outro olhar, um outro momento no conceito de documento histórico: na maioria das vezes havia coerência justificando ações hoje quase incompreensíveis. Os objetos têxteis foram e ainda são muito alterados nas instituições brasileiras, muitas vezes em instituições de renome que se propagam pioneiras no país em diversos campos de atuação museológica.

O trabalho de conservação realizado caracterizou-se uma vez mais pelo fazer роисо. Em nenhum momento foi cogitada a possibilidade de realizar-se um branqueamento do objeto. Apesar de sabermos que a má condição das fibras 
detectada pela microscopia desaconselharia uma lavagem aquosa com branqueamento, sabemos que a hipótese foi descartada a priori. A despeito do ganho visual temporário que oferece, o branqueamento é um processo prejudicial às fibras em geral e seu resultado de curta duração. Além disso, como mencionamos no início deste capítulo, restaurar o padrão de branco apropriado a esse objeto determinado exigiria uma série de pesquisas e informações não disponíveis no momento.

\section{Estudo de caso 7:}

\section{O TRABALHO DE CONSERVAÇÃO NA EXPOSIÇÃO TEMPORÁRIA LABIRINTO DA MODA - UMA AVENTURA INFANTIL. ${ }^{166}$}

Vista geral de uma das vitrines com indumentária infantil. (SESC-Pompéia)

A exposição Labirinto da Moda: uma aventura infantil foi uma grande exposição dedicada ao público infantil: "salas e corredores de tecidos criam cenários que estimulam o olhar e o brincar, contando o que foi a roupa, como tem sido apresentada no cinema e nas histórias e mostrando o que foi conservado pelos museus e pelas famílias. Milhares de imagens para

\footnotetext{
${ }^{166}$ A exposição aberta ao público de 15 de janeiro a 25 de fevereiro de 1996 foi uma iniciativa do SESC-Pompéia. Projeto idealizado e coordenado por Gláucia Amaral reuniu em sua versão original cerca de cem profissionais externos ao SESC ,em dezenas de atividades diferenciadas. Posteriormente, em versões menores e com equipes reduzidas, o Labirinto foi montado em Salvador (1996), e nas sedes do SESC em Santos (1997), São Carlos (1998), Bauru (1998), estando previstas outras duas montagens para o ano de 1999.
} 
instigar pequenos olhos agitados e ávidos por explorar o mundo, mostrando algumas formas do vestir que foram de terríveis e massacrantes a lúdicas e libertas, mas sempre diferentes do que hoje usam as crianças. Há vestidos para olhar e muitas peças antigas - ricas em rendas e bordados, preguinhas e suplícios - sendo o prazer feminino pelas roupas cultivado logo cedo pelas mães, que adoram brincar de boneca com suas filhas. Dos meninos não se têm quase nada, as roupas eram bem mais simples e com poucos enfeites, não ofereciam muitos atrativos. Os homens eram mais sérios e parece que só no carnaval eram fantasiados, embelezados e enfeitados para divertir a família.

Centenas de roupas podem ser descobertas nos baús do brechó, para se experimentar,admirar, dançar e exercitar a suprema liberdade de escolher. Convida-se a comparar a realidade à fantasia, as imagens bem desenhadas e comportadas dos figurinos antigos e a multidão caprichosamente vestida da Anna Heylen com as roupas fantasiosas e voadoras de Hishinuma." 167

\section{descrição}

Nosso trabalho de conservação na exposição Labirinto da Moda compreendeu as seguintes atividades:

1. planejamento e desenho dos manequins para os trajes antigos infantis das coleções envolvidas: Instituto Feminino da Bahia, Museu de Arte da Bahia, Museu Histórico Nacional, Museu Imperial, Museu Paulista da USP, Coleção Sylvia Athayde e Coleção SESC, num total de sessenta unidades;

2. acompanhamento, responsabilidade técnica, preparação, montagem, desmontagem, embalagem das coleções (incluindo aqui as roupas-peixe e roupas

\footnotetext{
${ }^{167}$ Glaucia Amaral (curadora), Uma aventura infantil: olhar a moda. Texto introdutório ao catálogo da mostra, homônimo.
} 
infláveis do estilista-artista japonês Yoshiki Hishinuma) e todas as demais atividades que envolvessem as coleções após sua chegada ao SESC. ${ }^{168}$

Embora a exposição tenha sido aberta em janeiro de 1996, o projeto teve início muito tempo antes. Nossas atividades tiveram início em setembro de 1995 tendo o trabalho direto com as coleções sido iniciado em meados daquele dezembro.

\section{estado de conservação das coleções}

O estado de conservação das coleções era bastante diferenciado. Todas as unidades de acervos da Bahia e parte da coleção do Museu Histórico Nacional foram restauradas em Petrópolis: foram lavadas, branqueadas, engomadas, tiveram suas fitas originais substituídas, forros originais trocados, tendo algumas unidades inclusive perdido a sua coloração durante estas operações ${ }^{169}$. O material foi enviado a São Paulo acondicionado em embalagens elegantes, repletas de lacinhos de cetim.

A coleção do Museu Paulista apresentava uma série de problemas de conservação. Várias unidades apresentavam grandes áreas com perda de suporte causada por insetos, manchas, oxidação e mesmo degradação das fibras no caso das fantasias em veludo de seda ${ }^{170}$.

\footnotetext{
${ }^{168}$ Toda a coleção do Instituto Feminino da Bahia e outras unidades de acervos fluminenses foram restaurados por outros profissionais em Petrópolis, Rio de Janeiro.

As unidades do Museu Paulista que participaram da exposição foram trabalhadas por nós, evidentemente, ainda no Museu Paulista.

${ }^{169}$ Cabe-nos esclarecer que este trabalho de "renovação" foi solicitado pela curadoria. Quando o trabalho nos foi proposto, declinamos, já que não víamos sentido profissional em realizá-los.

${ }^{170}$ Emprestar ou não emprestar um têxtil fragilizado para integrar uma mostra externa é sempre uma decisão difícil de ser tomada. Como quase sempre a palavra final sobre o assunto no Museu Paulista é de nossa responsabilidade, temos tentado adotar o seguinte critério. As unidades de acervo só são liberadas para empréstimo caso elas realmente sejam importantes à discussão que se pretende. Nos casos em que apenas serão um ítem a mais, um enfeite ou índice de variedade, o empréstimo é negado. No caso do LABIRINTO não só as roupas eram o tema central, como as unidades do Museu Paulista eram as únicas roupas
} 


\section{possibilidades de encaminhamento}

Como ocorre na maioria das vezes, no Brasil, os conservadores só passam a integrar a equipe de uma exposição quando o projeto museográfico já está definido e há que se conformar. A área de convivência do SESC- Pompéia, no verão, apresenta quase as mesmas condições climáticas extra-muro: temperatura alta, umidade relativa bastante elevada, luz solar direta e chuva direta devido a uma grande quantidade de goteiras. Do ponto de vista da conservação tudo estava incorreto.

Somava-se a isso o fato de não dispormos de uma área segura e fechada onde as roupas pudessem ser trabalhadas: poeira, café, tintas, escadas e fumantes circulavam de todos os lados, o tempo todo, ajudando a compor o quadro: missão impossível.

Era preciso, ao menos, transformar o péssimo em ruim.

\section{procedimentos adotados}

Para que as roupas pudessem ser retiradas das embalagens e preparadas, uma pequena área foi isolada e o acesso de pessoas portando qualquer tipo de objeto, material ou alimento foi vetado. Por todo o local foram espalhadas etiquetas com os dizeres POR FAVOR NÃO TOQUE. O mesmo aconteceu por ocasião da montagem das vitrines, até a colocação dos vidros.

Cada uma das peças recebeu uma ficha de montagem onde foram anotadas particularidades, problemas detectados, soluções adotadas na montagem bem como o tempo gasto na preparação de cada um dos trajes.

de inverno, de cores escuras, em seda e lã geralmente. O restante das coleções era formado por roupas leves, brancas, "roupas de verão". De qualquer modo haveria uma série de cuidados e pequenos reparos que poderiam ter sido executados caso houvesse tempo hábil para que os trabalhos fossem desenvolvidos com seriedade e segurança. Ou as roupas eram emprestadas praticamente na situação em que se encontravam ou não integrariam a mostra. Afinal o que mais importava ? O resultado final causou uma polêmica inesperada durante a mostra! 
1. Os manequins foram confeccionados sob medida para cada uma das roupas. Não possuíam braços nem cabeças e foram revestidos com malha de algodão na cor bege claro ${ }^{171}$.

2. Os manequins sofreram pequenas adaptações individuais, conforme a estrutura da roupa demandava. Aqueles projetados para as roupas de crianças "com fralda" receberam enchimentos; saias armadas receberam forros endurecidos; calças receberam "suspensórios" de segurança; as roupas de inverno e as fantasias de manga comprida receberam "braços" internos. Todos esses acréscimos foram feitos com manta acrílica e malha de algodão.

3. Todas as peças e/ou acessórios que foram expostas horizontalmente no chão ou prateleiras das vitrines, foram protegidas por folhas de papel poliéster cristal, gramatura 0,3 da RHODIA.

4. Todas as roupas brancas e/ou de cores claras, basicamente em tecido de algodão, foram expostas nas vitrines que recebiam maior quantidade de luz. As roupas em seda e/ou lã, de cores escuras, foram expostas nas vitrines com luminosidade menos intensa. ${ }^{172}$

5. Um vestido de etamine acompanhado de capa e véu, todos bordados em fio de prata, recém-restaurados, muito frágeis e pesados, precisaram ser expostos sobre um cubo e duas barras, como trapézios pendurados, todos revestidos e

\footnotetext{
${ }^{171}$ Aqui vale a pena um comentário.No Brasil inexistem critérios e prática na medição de indumentária. Assim tanto a curadoria quanto a restauradora no Rio de Janeiro nos forneceram medidas absolutamente irrelevantes para se projetar uma estrutura ou manequim. Para obedecer o cronograma previsto $90 \%$ dos manequins foram projetados por "suposição". O grande índice de acerto deveu-se mais ao acaso do que a alguma técnica especial aprendida na Inglaterra, como as pessoas preferem acreditar. Sobre a importância da interpretação adequäda dos trajes em suas dimensões, e outras questões relativas à forma de apresentação da indumentária em exposições vide: Véronique Monier Mannequins et mannequinage; leur incontournable raison d'être IN LA CONSERVATION DES TEXTILES ANCIENS. Journées d'Études de la SFIIC. Angers, outubro de 1994. pp 131-140.

${ }^{172}$ Apenas como referência. A faixa de iluminamento recomendada para um têxtil é de 50 a 100 lux. Em algumas horas do dia as vitrines mais iluminadas registravam 300 lux.
} 
acolchoados, já que a vitrine que foi projetada para recebê-lo era alta e estreita, ideal apenas para exposição em total verticalidade.

6. Por medida adicional de segurança os tetos das vitrines foram cobertos com plástico.

7. Devido a grande quantidade de poeira no local, as vitrines foram lacradas com silicone para minimizar o problema.

8. Inspeções semanais foram realizadas durante o período de exposição.

\section{comentário final}

Trabalhar fora de nosso local rotineiro de trabalho é sempre uma experiência importante. Neste caso por tratar-se de um contexto não museológico então, a experiência veio potencializada e impôs uma série de reflexões.

Do ponto de vista técnico fomos obrigados a buscar variadas alternativas que minimizassem as péssimas condições ambientais, o que nem sempre foi bem sucedido. Estes problemas todos, entretanto, tornaram-se menores, secundários mesmo, diante da importância de um projeto como aquele: um museu-circo, um vale tudo de tecidos, botões e texturas como nunca se tinha visto.

Vista geral da vitrine, ainda em montagem, com fantasias e roupas étnicas. (SESC-Santos)

\section{analisando o que foi feito}

São várias as questões a serem apontadas nesta experiência específica.

-Todo profissional de museu sonha em participar de um projeto dessa natureza: um projeto belíssimo, a oportunidade de trabalhar com profissionais experientes por quem se tem grande admiração e uma infra-estrutura financeira e administrativa incomuns dentro da área museológica. $\mathrm{O}$ único critério a reunir aqueles profissionais era competência em suas áreas de especialidade. Ao mesmo tempo, a experiência se apresentava como um teste profissional, pessoal, 
distante da pequena demanda e "proteção" que os pequenos eventos dos museus proporcionam aos que lá trabalham. Fascinante, também, era a oportunidade de estar num local onde todas as pessoas trabalhavam criativamente com tecido, conheciam tecidos e eram capazes de se maravilhar ao tocar uma bela textura ou um fio diferenciado.

- Acreditamos que o Labirinto tenha sido um marco em nossa prática profissional, já que nos obrigou a repensar uma série de questões teóricas, toda a cartilha inglesa dos MUST e dos MUST NOT transplantada para as nossas atividades no Museu Paulista, conforme já discutimos anteriormente. Foi possível encontrarmos um meio termo entre o ideal da conservação e o projeto da curadoria.

-Uma controvérsia inesperada acabou surgindo durante a exposição. Por quê as coleções históricas - com exceção da pertencente ao Museu Paulista-, haviam recebido um outro tratamento de conservação? Por quê elas pareciam novas, estavam limpas e bem passadas e as roupas do Museu Paulista traziam manchas, furos e mesmo rasgos? Estas perguntas começaram a surgir de todos os lados já que a diferença visual era bastante grande, iniciando um debate que acabou integrando o treinamento dos monitores e discurso dos arte-educadores. Apenas esta discussão, acreditamos, já teria feito todo o nosso trabalho ter valido a pena! As roupas da coleção do Museu Paulista - apelidadas pela equipe de "feios, sujos e malvados" encontravam-se 'sujas e feias' por dois motivos básicos: 1. não houve tempo disponível para que os objetos fossem conservados dentro dos critérios estabelecidos para a instituição, além do fato de internamente tais trabalhos não serem prioritários. Acreditamos não ser possível 'conservar' dezenas de roupas, de forma responsável, num período de três meses. 2. Não somos necessariamente contra determinados tipos de tratamento, desde que eles 
se justifiquem. Entretanto o critério estético, no Museu Paulista, não será nunca preponderante sobre todos os outros .

Foram explicados à curadoria e equipe os problemas causados pelo clareamento: a lavagem aquosa e o posterior branqueamento a que foram submetidas várias das roupas que integraram a mostra causaram danos visíveis (perda das cores em alguns casos) e outros estruturais. O clareamento dos tecidos e mesmo de algumas manchas é sempre temporário: tempos depois nova oxidação se verifica e a antiga aparência retorna: a diferença é que as fibras, depois de um branqueamento, foram enfraquecidas em até $50 \%$. O branqueamento, portanto, é

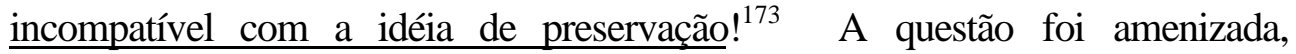
evidentemente, sendo explicado ao público, apenas, que as diferentes instituições brasileiras possuem opiniões diferenciadas sobre o modo como os tecidos históricos devem ser preservados.

- O contexto da exposição, evidentemente, influenciou muitas de nossas decisões. A exposição era o não-museu que temos (talvez o museu que desejemos):o lugar onde tudo poderia e deveria ser tocado, sentido, experimentado. As vitrines com roupas e brinquedos antigos - naquele contexto , eram apenas o contraponto, a referência temporal da exposição.

- Outro fator a ser mencionado é que o SESC financiou a restauração das coleções (independentemente da forma como tenha sido conduzida), a confecção das embalagens e manequins. Após a exposição, embalagens e manequins foram doados às instituições proprietárias das roupas com a condição de que a cada nova edição do Labirinto esses retornassem. E aqui temos alguns pontos a comentar: hoje, após outras edições da exposição pudemos constatar o que também fora discutido com a curadoria:

\footnotetext{
${ }^{173}$ Hoje esta questão pode ser verificada nas novas montagens. Os tecidos branqueados já estão escurecendo, as manchas voltaram e os adesivos utilizados na consolidação de
} 
1. as embalagens sofisticadas e cheias de lacinhos não sobreviveram ao manuseio em instituições onde inexistem conservadores;

2. as caixas confeccionadas para o transporte das peças foram utilizadas como armários por algumas instituições e assim, nas edições seguintes, as roupas foram ‘compactadas' numa mesma e única caixa. Conclusão: soluções mais sofisticadas não surtem efeito quando a idéia de segurança e de transporte correto não é compreendida pelos funcionários responsáveis pelas coleções. Nestes casos, politicamente correto ou não, o menos quase sempre é mais! Sofisticação e exagero, em conservação, não são sinônimos de qualidade.

\section{Estudo de caso 8:}

\section{A CONSERVAÇÃO DE UM TRAJE VERMELHO DE SAMURAI ${ }^{174}$.}

Par de manoplas com manga (tekkó - kote) depois de conservadas.

\section{descrição}

Traje incompleto de samurai, basicamente vermelho, composto das seguintes partes:

1.Proteção facial ou máscara (sô-men): estrutura de sete barras metálicas verticais que terminam na parte inferior em um tecido acolchoado, com pequenos discos em metal. Todo o canto superior esquerdo, desde o centro, é feito em papelão. Duas faixas em seda adamascada perpassam a máscara no sentido leste-oeste, sendo uma na extremidade superior e outra antes da área em tecido.

algumas áreas fragilizadas reagiram com o ambiente, provocando o escurecimento do tecido nos pontos onde foi aplicado.

${ }^{174}$ Coleção Museu Paulista RG 3744. Foto José Rosael. 
2. Corpo central da armadura $(d \hat{)})$ : estrutura em metal, laqueada internamente, à qual se prendem, na região dos ombros, duas 'ombreiras' em tecido e metal (sode). Na parte inferior, penduradas por inúmeros cordões de seda, prendemse 07 bandas (kusazuri) igualmente feitas de metal e cordões de seda, sendo que quatro se localizam na parte anterior e três na posterior.

3. Avental (haidate). Avental em tecido celulósico, provavelmente linho, em comprimento que se estende da cintura até os joelhos, quase inteiramente dividido ao meio no sentido sul-norte, com duas extensões de tecido nas laterais de cada metade. Sobre o tecido, no anverso, encontram-se costuradas uma trama metálica e pequenos quadrados igualmente em metal que cobrem cerca de $70 \%$ da área total. Os $30 \%$ restantes são cobertos por tecido de seda. Uma faixa em papel, entre duas linhas de vivos em fios de seda multicoloridos, separa as duas áreas.

4. Par de manoplas com manga (tekkó - kote). Duas manoplas com manga feitas em tecido celulósico, provavelmente linho, sobre o qual se encontram - da mão para o ombro - partes em metal na região das mãos e malhas metálicas com pequenos quadrados e retângulos em metal. No anverso o tecido é separado em duas partes e atado por um cordoamento que perpassa toda sua extensão.

5. Proteção peitoral Estrutura de formato irregular acolchoada com algodão, medindo em suas máximas $28 \times 44 \mathrm{~cm}$, onde na parte superior do anverso encontra-se uma faixa de tecido de seda sobre a qual foram aplicadas pequenas contas metálicas. O verso é todo em tecido de seda adamascado com motivos florais.

\section{estado de conservação}


Regular/Mau. O traje foi encaminhado ao atelier junto com outro exemplar bem mais complexo e mais elaborado ${ }^{175}$. Na verdade acreditava-se que o museu possuísse apenas uma armadura de samurai, presente do governo japonês no centenário da Independência. Nenhuma outra informação constava em sua documentação. Ambos estavam embrulhados juntos, em papel ácido tipo craft, sendo que o corpo central da outra armadura estava sustentado por uma lata de tinta vazia ${ }^{176}$. O traje apresentava sujidade generalizada. Todos os elementos têxteis traziam distorções, perdas de suporte significativas (15-30\%) e processo ativo de decomposição. A estrutura metálica principal, separada em duas partes, apresentava problemas de oxidação avançada e desprendimento da camada de esmalte(?) que a recobre.

\section{possibilidades de encaminhamento.}

Não havia nenhuma informação disponível sobre o traje. Até hoje foram encontradas apenas referências a outra armadura da coleção. $O$ desconhecimento total sobre os materiais não têxteis ali encontrados e o fato, também, do traje estar incompleto não colocaram muitas dúvidas quanto ao procedimento a ser adotado: era preciso higienizar a peça, documentá-la e buscar a melhor forma de acondicioná-la. Os problemas sérios de oxidação do metal e deterioração da camada que a reveste teriam que ser abordados por um especialista em conservação de metais, especialidade não disponível no país. Neste caso o limite de nossa ação era bastante preciso: acondicionar as partes,

\footnotetext{
${ }^{175}$ Coleção Museu Paulista RG 1160.

176 Estes pacotes, juntamente com outros objetos, integravam o grupo dos grandes problemas no acervo que há muito não eram sequer olhados. Por ocasião do recadastramento das coleções e "abertura de todos os armários", iniciado em 1989 vários objetos foram "descobertos" pelas equipes e então trabalhados segundo as possibilidades e prioridades estabelecidas.
} 
todas pesadas, irregulares e frágeis do melhor modo possível e proteger os têxteis contra maiores danos.

\section{procedimento adotado}

1. os elementos têxteis foram limpos através de micro-aspiração. Apenas as faixas da cintura do avental, muito distorcidas mas de fácil acesso, foram limpas com esponja umedecida em água destilada sobre papel absorvente.

2. A superfície metálica foi limpa mecanicamente com swob em solução $50 \%$ etanol $\mathrm{C}_{2} \mathrm{H} 5 \mathrm{OH}, 50 \%$ metanol $\mathrm{CH} 3 \mathrm{OH}$.

3. As partes foram acondicionadas individualmente em pranchas de polietileno incolores POLIONDA®, 3mm. O suporte das partes mais pesadas foi construído sobre duas ou mais pranchas costuradas entre si com fio de pesca de poliamida ARATY®, 0,20mm.

4. Para construção dos suportes foi utilizada manta acrílica e tecido de algodão não alvejado, variando em altura e espessura conforme os diferentes pesos das partes exigiram.

6. Devido ao peso dos metais foram colocados acolchoados entre as partes e as bases- igualmente produzidos com manta acrílica e tecido de algodão não alvejado, - com o objetivo de amenizar o desgaste das partes inferiores a longo prazo.

7.Para evitar que as bandas pudessem deslizar no sentido lateral, foram costurados à base dos corpos centrais da armadura dois pequenos retângulos de ETHAFOAM ®.

8. As extremidades de cordões e fios fragilizados, assim como a proteção peitoral, foram acondicionados em sanduíche de tule sintético e, sempre que possível, costurados às bases. 
9. Todas as partes, nas bases, foram cobertas com tecido de algodão não alvejado $^{177}$.

\section{comentário final}

O trabalho realizado com o traje possibilitou sua documentação e garantiu o acesso eventual de futuros pesquisadores e interessados ao objeto. Entretanto os problemas concernentes a outras áreas de especialidade, cabe dizer, não foram resolvidos, tampouco estabilizados.

\section{analisando o que foi feito}

Este caso foi apresentado neste ensaio com o objetivo de ilustrar algumas situações freqüentes nos museus. A primeira diz respeito ao inusitado, ao improvável dentro das coleções. Técnicamente o acervo do Museu Paulista é composto de objetos relacionados a cultura material da sociedade paulista e/ou brasileira do período 1850-1950. Entretanto são muitas as excessões e às vezes elas são bastante estranhas como nesse caso específico, obrigando o profissional conservador a estudos muito especiais .

Uma segunda observação poderia ser feita em relação à natureza do objeto e de sua classificação como 'têxtil'. De um modo geral, mundo afora, todos os trajes e indumentária como um todo acabam sendo responsabilidade da área têxtil mesmo que se apresentem em outros materiais. Cabe ao conservador de têxteis, nesses casos, solicitar a parceria de outros profissionais:o conservadorcientista, politicamente correto e obediente às normas éticas internacionais da profissão, deve saber quando parar ou mesmo quando nem sequer iniciar determinados projetos. É importante mencionar, entretanto, que a consulta a colegas e instituições estrangeiras é bastante comum e se encontra hoje bastante

\footnotetext{
${ }^{177}$ É preciso mencionarmos, aqui, que todas as unidades de acervo conservadas retornam à reserva técnica cobertas. A medida visa proteger os objetos de futuros depósitos de poeira.
} 
facilitada pela informática. Os profissionais da área têxtil já contam há dois anos com um canal específico para discussões e consultas. ${ }^{178}$

Neste caso, mais uma vez, tratava-se de um projeto não prioritário dentro daquele momento institucional. Trazer um especialista do estrangeiro poderia e deveria ser feito caso o investimento se justificasse, o que não era o caso. $O$ prioritário naquele momento era acessar o objeto, fotografá-lo, documentá-lo e protegê-lo da melhor forma possível. Uma vez mais constatamos o less is more como a principal tendência na atitude dos profissionais de museus hoje.

\section{Estudo de caso 9:}

A CONSERVAÇÃO DE UMA BANDEIRA IMPERIAL DA GUARDA NACIONAL DA PROVÍNCIA DE SÃO PAULO ${ }^{179}$.

Detalhe da área do losango depois de aberta.

\section{descrição}

${ }^{178}$ Textile Conservation List TEXCONS é um foro de discussão sem moderadores de responsabilidade de Mary W. Ballard, da Smithsonian Institution e S. Gail Niinimaa da Austrália. O serviço é financiado pela Stanford University Libraries, Estados Unidos. As discussões podem ser acessadas por qualquer interessado no http://palimpsest.stanford.edu/byform/mailing-lists/texcons/ . Para integrar a lista basta escrever para majordomo@simsc.si.edu. 
Bandeira similar a bandeira brasileira do Império, em cetim de seda e impressões em quatro cores. Abaixo dos elementos tradicionais há uma faixa impressa com os dizeres "Batalhão da Guarda Nacional da Província de São Paulo". Em cada um dos quatro cantos há impressões de um brasão com as letras "G.N.", circundado por ramos de café e tabaco.

\section{estado de conservação}

Mau. A bandeira, de grandes dimensões, chegou ao atelier muito dobrada em área que não excedia o tamanho desta página. As partes estampadas encontravam-se todas aderidas umas às outras. A seda (heavy silk) encontravase muito frágil e bastante fragmentada. As partes misturavam-se a uma enorme quantidade de sujeira.

\section{encaminhamentos possíveis}

Nesse caso, num primeiro momento, não havia muito a decidir. Era preciso abrir a bandeira: uma operação de risco, sem alternativas.

\section{procedimentos adotados}

1. Foi providenciada uma grande tábua de madeira com cavaletes que foi coberta com um único grande plástico.

2. Em seguida as tintas da impressão foram testadas com swob em água destilada, mostrando-se resistentes.

3. Uma 'tenda' foi montada e dentro dela foram colocados, além da bandeira dobrada, vários tecidos úmidos. A umidade relativa na tenda foi controlada com higrômetro para que atingisse entre 80 e $90 \%$.

\footnotetext{
${ }^{179}$ Coleção Museu Paulista RG 390
} 
4. Nessa situação a bandeira começou a ser aberta mecanicamente, lentamente e, a cada movimentação diária que não excedia $1 \mathrm{~cm}$, pequenos paralelepípedos de espuma de polietileno eram colocados na abertura a fim de evitar o retorno da movimentação. Note-se que no final de cada dia a 'tenda' era aberta evitando o risco de condensação.

5. Assim seguiu-se trabalhando, aumentando-se os apoios até que a primeira dobradura foi desfeita. $\mathrm{O}$ mesmo procedimento foi adotado até que todas as dobraduras foram eliminadas.

6. Nesse processo todas as partes soltas foram guardadas para futura limpeza.

7. Com a bandeira aberta verificou-se que apenas a grande área do losango encontrava-se inteira, embora cheia de distorções causadas por duas linhas de costura, em forma de cruz, e pelas áreas impressas.

8. Iniciou-se então o trabalho de relaxamento das fibras. Do centro para as bordas, em todas as direções, foram utilizados pequenos retângulos de polietileno para induzir a movimentação das fibras.

9. O mesmo procedimento foi sendo adotado, paralelamente, com as pequenas partes impressas dos quatro cantos. Depois de colocadas nos locais certos remontando o desenho (assim como um quebra-cabeças), as partes foram limpas mecanicamente com trincha.

10. Depois de três meses a bandeira encontrava-se 'planificada'. Devido a suas dimensões optamos por não reunir as partes soltas ao losango central. Cada canto foi remontado dentro de um 'sanduíche' de tule, separadamente, tendo o mesmo ocorrido com outras áreas soltas de maior extensão.

11. O losango também foi protegido entre dois tules.

12. As pequenas partes foram guardadas em embalagem devidamente identificada de polietileno de baixa densidade, com fecho hermético, FREEZER ®, de uso doméstico. 
13. Devido a suas dimensões a bandeira precisou ser dobrada na gaveta de mapoteca onde foi acondicionada. Foram confeccionados, então, vários apoios (pequenas almofadas) em manta acrílica e malha de algodão para que fornecessem a sustentação necessária àquelas àreas.

14. Ao todo a bandeira encontra-se desmembrada em 07 partes que, se colocadas lado a lado 'formam' a bandeira completa.

\section{comentário final}

O trabalho foi bem sucedido não tendo sido registrado nenhum dano a qualquer uma das partes. A bandeira - ao que tudo indica única no país,- foi desenhada, fotografada e se encontra protegida e acessível.

\section{analisando o que foi feito}

A conservação de bandeiras é sempre assunto de uma série de discussões. Vários simpósios internacionais, grupos de pesquisa e centros de estudo dedicam-se exclusivamente a esse assunto ${ }^{180}$. São objetos grandes, recortados, com aplicações, repletos de simbologia e cuja conservação, geralmente impõe uma série de consequências como 'perda' de um dos lados, perda da sua flexibilidade, etc.

\footnotetext{
${ }^{180}$ Sobre os procedimentos e métodos mais utilizados na conservação dessa tipologia de têxteis vide, em especial, o artigo de Pat Trautman. Nele discute-se o trabalho de conservação desenvolvido com uma coleção de mais de 160 bandeiras de batalha, de propriedade do estado de Connecticut, Estados Unidos. Stabilization and documentation of Connecticut's State battle flags: one aproach to the presentation of an entire collection. IN: FLAG SYMPOSIUM, Harrisburg, Pennsylvania Capitol preservation committee, Oct. 1987.
} 
A maioria dos pedidos de assessoria que nos são encaminhados por outras instituições brasileiras, tratam da conservação de bandeiras. Elas são muitas em todo e qualquer museu histórico brasileiro e, geralmente, apresentam os mesmos problemas: seda em decomposição, mudança nas cores originais, manchas d'água, distorções, etc. Seu acondicionamento é igualmente difícil de ser resolvido a contento. A maioria não poder ser acondicionada em cilindros: o que fazer então?

A solução dada a esse caso descrito foi repetida em várias unidades do acervo do Museu Paulista, principalmente com as bandeiras brasileiras da República, todas em péssimas condições, todas muito parecidas; objetos que apesar de já terem merecido um estudo específico de nossa parte, apresentado em reunião da SBPC anos atrás ${ }^{181}$, dificilmente serão alvo do interesse de pesquisadores. No trabalho com essa coleção de bandeiras - a despeito das idéias de reversibilidade, intervenção mínima etc -, talvez tenha sido preponderante, sempre, a noção de importante. Perigosamente, nesses casos, a avaliação parte apenas de um profissional, baseia-se em uma única opinião.A vantagem desse tipo de trabalho, entretanto, reside no fato dele não excluir nenhuma possibilidade futura de ação, dele possibilitar - como o fim do milênio sugereque futuros profissionais, pensando diferentemente, venham a agir sobre eles com métodos e intenções hoje impensáveis.

\section{Estudo de caso 10:}

\footnotetext{
${ }^{181}$ Restauração de tecidos Históricos: os problemas de conservação da bandeira brasileira. Comunicação apresentada na 45 reunião anual da SBPC, Recife, 1993.
} 


\section{A CONSERVAÇÃO DA JAQUETA DE MÚSICO DA BANDA CASA DE SAVÓIA, PERTENCENTE AO MUSEU HISTÓRICO DE SÃO CAETANO DO SUL.}

Vista geral da jaqueta antes do trabalho de conservação.

Esse projeto de trabalho surgiu após um pedido de assessoria daquela instituição. Segundo o museu e a Fundação Pró-Memória da cidade nos explicaram, uma série de comemorações iriam acontecer na cidade de São Caetano em 1996, sendo sua intenção que a Jaqueta itinerasse por vários locais da cidade ao lado de alguns instrumentos da Banda Casa de Savóia. A Banda Casa de Savóia, no início do século XX, foi formada pelos chefes das famílias italianas fundadoras da cidade, daí sua importância na história da cidade.

Foi realizado um projeto completo de intervenção, a ser financiado pela instituição solicitante, na qual previram-se as seguintes etapas: documentação completa, conservação, projeto e confecção de suporte para exposição, confecção da embalagem para transporte da jaqueta montada e projeto de vitrine para exposição. Todo o trabalho seria documentado e reproduzido em duas $\operatorname{vias}^{182}$.

O projeto foi desenvolvido em seis meses, gerou um relatório final de mais de cinqüenta páginas com todas as etapas do processo descritas em textos, tabelas, dezenas de cromos e desenhos digitais. Alguns exemplos da documentação realizada foram anexados ao final desta dissertação.

\footnotetext{
${ }^{182}$ Quase sempre os custos visam cobrir despesas com material fotográfico, despesas com tecidos, fios e outros materiais utilizados na conservação e confecção de embalagens ou outros. O restante da verba solicitada foi utilizada para o pagamento de dois estagiários bolsistas que trabalharam conosco no projeto durante seis meses. $\mathrm{O}$ custo aproximado do projeto, em 1996, foi de $\mathrm{R} \$ 10.000,00$ (dez mil reais), num total aproximado de 340 horas de trabalho.
} 
Após o término dos trabalhos organizamos um seminário no Museu Paulista para todos os funcionários do Museu Histórico de São Caetano, durante o qual, explicamos, passo a passo, todas as etapas do trabalho e os cuidados futuros que seriam necessários à preservação da jaqueta em boas condições.

\section{descrição}

Jaqueta em tecido de lã (sarja 2/2) com forro de tecido de algodão, tipo japona, gola dobrada, abotoada no anverso em uma das duas séries verticais de quatro botões metálicos. Na região dos punhos e por toda a sua volta apresenta dois vivos - um dourado e um vermelho, - e dois pequenos botões metálicos. No verso inferior a jaqueta possui uma região central com pregas, em cujas laterais há um vivo vermelho com botões metálicos nas extremidades. Todos os botões possuem o desenho de uma lira em alto relevo.

\section{estado de conservação}

Mau. O objeto encontrava-se bastante fragilizado, com a lã em avançado estado de decomposição. Havia sujidade generalizada, manchas diversas, grandes áreas de distorção, remendos e costuras aplicadas principalmente na região dos ombros. As áreas de lã com perda de suporte excediam os 5\%. Faltavam-lhe cinco dos botões originais, quatro frontais e um traseiro. Além disso o casaco fora adaptado a uma outra forma, como se fosse um paletó ou japona com a gola dobrada para fora.

\section{possibilidades de encaminhamento}

O frágil estado de conservação e a preparação do objeto para exposição itinerante, impunham alguns procedimentos. Foram considerados, basicamente, os seguintes pontos:

-o estado de decomposição das fibras; 
-as propriedades das fibras de lã (higroscopia, elasticidade, etc);

-a construção do casaco (linhas de corte e montagem do tecido, peso, sustentação das diferentes partes);

-o objetivo dos curadores de expô-lo em caráter permanente;

-o caráter documental do objeto;

- grau de risco de vários procedimentos.

A análise microscópica evidenciou o estado de decomposição das fibras, já quebradiças, que ocasionavam um 'esfarelamento' da lã. Esta tal condição de fragilidade descartou a hipótese de lavagem, visto que as fibras poderiam não suportar tanta movimentação. Além disso, sabe-se, uma lavagem aquosa ou a seco demandaria a remoção de todos os elementos metálicos (botões e frisos) causando a perda das costuras originais.

Deste modo ficou definido que a limpeza do casaco seria feita mecanicamente, com pincel e trincha e que as manchas seriam trabalhadas caso a caso. As costuras antigas, que causavam distorções, seriam removidas e as áreas muito frágeis receberiam enxertos internos de tecido e externo de proteção. Todos os tecidos seriam aplicados com costura, descartando-se o uso de qualquer adesivo.

\section{procedimentos adotados}

1. A jaqueta foi fotografada em detalhes com identificação das áreas.

2. Todas as dimensões da jaqueta foram anotadas, já que nesses casos costumam ocorrer alterações significativas em algumas medidas.

3. Todos os detalhes foram minuciosamente desenhados em escala: linhas de costura, rasgos, rasgos com costura, manchas, distorções com costuras irregulares, etc. 
4. Foi construído um suporte interno para o casaco a fim de garantir-lhe sustentação durante a execução dos trabalhos (um 'boneco' em manta acrílica e tecido de algodão).

5. A maior parte da sujidade depositada sobre o tecido foi removida mecanicamente com trincha e microaspiração.

6. As manchas foram removidas com $s w o b$ em água destilada, sob ventilação constante e aplicação de papel absorvente.

7. A hidratação das fibras foi realizada com umidificador ultrasônico em cinco seções de 2 minutos.

8. Quase todas as recosturas foram removidas.

9. A restauração gradual da forma original do casaco aconteceu através de indução das partes à posição correta.

10. Enxertos de tecido (voal de poliester) foram fixados por pontos de costura (corrido, reto, cruzado, cruzado invertido, posado, alternado e de segurança) com fios desfiados do voal, para sustentação das áreas com rotura.

11. Foram aplicados reforços externos com tule de nylon e fios de poliester nas áreas especialmente fragilizadas (costas central e braços).

12. Inseriram-se ombreiras confeccionadas com filme de polietileno, malha de algodão e voal de poliester.

13. Os botões foram reposicionados.

14. Falsos botões foram produzidos em resina.

15. Providenciou-se a costura dos falsos botões.

16. Seguiu-se a preparação do suporte definitivo encomendado, feito em fibra de vidro com dimensões máximas de $45 \times 80 \mathrm{~cm}$, coberto com malha de algodão preta. A ele foram fixados, por costura, dois 'braços' feitos em manta acrílica e cobertos com o mesmo tecido.

17. O casaco foi acomodado no suporte definitivo. 
Paralelamente ao trabalho de conservação por nós executado, os estagiários trabalharam na construção de maquetes dos projetos de embalagem para transporte, e da vitrine que abrigaria a jaqueta.

O projeto de embalagem para transporte considerou os seguintes pontos:

- fragilidade do material da jaqueta;

- segurança do objeto;

- não movimentação do objeto através de pressão controlada;

-resistência ao impacto;

-manuseio e transporte da embalagem por profissionais não especializados.

Os materiais escolhidos foram: madeira, algodão não alvejado e pranchas de polietileno incolores POLIONDA®, 3mm, considerando-se as seguintes vantagens: resistência, baixo custo, facilidade de adaptação de formas e dimensões, adaptabilidade aos outros materiais.

Foram construídos 'acolchoados' em manta acrílica e recobertos com algodão não alvejado, para garantir a pressão necessária à permanência do objeto em lugar determinado. Cintos, segurando as áreas dos braços e torax, foram realizados com os mesmos materiais e com a mesma finalidade. Várias partes de POLIONDA ${ }^{\circledR}$ foram colocadas nas partes superior e inferior da caixa onde inexistiam os acolchoados. Todos os materiais internos foram fixados à madeira com tachas de cobre FTP ${ }^{\circledR}$ n. 2, $11 \mathrm{~mm}$. A embalagem quadrada abria-se frontalmente (com tampa removível) e articulava-se para fora nas duas laterais.

O projeto de vitrine proposto ao Museu Histórico de São Caetano do Sul considerou basicamente os seguintes pontos:

-segurança do objeto;

-leitura correta; 
-disponibilidade dos materiais.

A idéia inicial dos curadores, de expor uma tuba apoiada sobre a jaqueta, foi desaconselhada devido a condição frágil do objeto. Recomendou-se ainda,que a vitrine fosse corretamente vedada e que ficasse em local seco, com pouca luminosidade.

Vista geral da jaqueta já na vitrine para exposição itinerante

\section{comentário final}

O trabalho alcançou todos os seus objetivos já que as soluções encontradas não só garantiram a preservação do objeto como também satisfizeram as exigências dos curadores. A jaqueta foi exposta em diferentes locais da cidade de São Caetano e o trabalho realizado foi tema de discussão na imprensa local.

\section{analisando o que foi feito}

Este projeto de intervenção foi um longo exercício de aplicação de técnicas de costura, basicamente. Em nosso entender o trabalho de costura, dentre todas as atividades da conservação de têxteis, talvez seja o mais difícil de ser realizado. Trabalha-se com fios praticamente invisíveis durante longos períodos de tempo. A atividade exige muita concentração e muito controle dos movimentos e mesmo respiração. Aqui cabe um comentário: mais do que qualquer outra atividade, este trabalho específico requer serenidade e paz interior por parte do conservador. De outro modo ele simplesmente não acontece de forma satisfatória.

Objetivamente o trabalho nos ofereceu a oportunidade de trabalhar na conservação do importante, nos termos colocados no início deste ensaio. Era um projeto que fazia sentido, que justificava todo o tempo e investimento despendidos. A história da banda Casa de Savóia é conhecida pela população de São Caetano: aparentemente todo mundo teve um familiar integrante do grupo musical. Outro fator a destacar foi o fato da jaqueta ser exposta fora do museu, 
nos locais onde as festas da cidade iriam acontecer. Nesse caso houve um para $q u \hat{e}$ imediato a justificar a ação.

Uma última observação deve ser feita aqui por ser inédita neste ensaio. Diz respeito ao acréscimo de elementos 'supérfluos' (do ponto de vista estrutural) ao objeto original: nesse caso, os botões produzidos com resina.

Ao final dos trabalhos, com a jaqueta colocada em seu suporte definitivo, ficou evidente o vazio, a quebra do conjunto causada pela falta dos botões. E essa falta na verdade chamava sobre si muita atenção, daí nossa opção por reproduzi$\operatorname{los}^{183}$.

\title{
4. Um arremate necessário.
}

\begin{abstract}
Quem se examina de perto raramente se vê duas vezes no mesmo estado. Dou à minha alma ora um aspecto, ora outro, segundo o lado para o qual me volto. Se falo de mim de diversas maneiras é porque me olho de diferentes modos... E quem quer que se estude atentamente reconhecerá igualmente em si, e até em seu julgamento, essa mesma volubilidade, essa mesma discordância. Não posso aplicar a mim mesmo um juízo completo, simples, sólido, sem confusão nem mistura, nem o exprimir com uma só palavra. ${ }^{184}$
\end{abstract}

Como ficou evidente nem sempre pensamento e trabalho prático caminham num mesmo ritmo: ora a idéia avança sobre a prática lhe oferecendo novas possibilidades, ora é a prática que vem sugerir o que ainda não se fez idéia:

\footnotetext{
${ }^{183}$ A inclusão de elementos estranhos ao objeto por razões estéticas é geralmente aceita nos meios museológicos com tranqüilidade, desde que indicada nas etiquetas e/ou publicações. Em outras áreas de trabalho equivaleria, por certo, a agregar uma nova moldura à uma pintura de cavalete ou providenciar um novo pneu para uma bicicleta. Uma exposição sobre a história das bicicletas organizadas pelo Design Museum de Londres, em 1998, trazia várias unidades com pneus substituídos.

${ }^{184}$ Montaigne. APUD: Eduardo Gianetti, op.cit. p.95
} 
neste contexto específico de discussão a ordem dos fatores necessariamente altera o produto.

Nos trabalhos de conservação de têxteis desenvolvidos no Museu Paulista procurou-se sempre trabalhar com dois pontos de vista: o ideal e o possível. Apesar da inevitável subjetividade dos termos eles nos são úteis, aqui, para definir dois níveis de preocupação diferenciados. O primeiro ponto de vista, o ideal, requer constante avaliação e talvez venha sempre relacionado ao contexto internacional tanto de práticas quanto de idéias; já o segundo, o possível, é aquele sobre o qual se constroem novas possibilidades, novas alternativas de trabalho. Quer o desejemos ou não, como se nota nos estudos de caso apresentados, ambos estão presentes em todas as etapas do trabalho.

Nosso objetivo principal ao apresentar os dez estudos de caso foi registrar neste ensaio o modo como os trabalhos de conservação de têxteis foram se desenvolvendo e quais as idéias, critérios e escolhas determinantes em sua concretização. A intenção maior, sem dúvida, foi refletir e deixar registradas algumas das decisões tomadas e as circunstâncias que as determinaram.

Um dos principais motivos a impedir o avanço dos estudos de conservação no Brasil, em nosso entender, é a falta de registro e de reflexão sobre o que se faz e o que já se fez por aqui. Estamos sempre começando tudo outra vez e isso, dentro deste contexto específico, não é sinal de renovação e mudança, mas de descontinuidade e perda de tempo. A geração de profissionais que nos antecedeu em São Paulo, prematuramente falecida, pouco se preocupou em registrar seus estudos, idéias e projetos -tivessem eles se materializado ou não. Desse modo sólidas experiências de trabalho foram perdidas, laboratórios de conservação foram desarticulados, num movimento contraditório em sua essência, quer dizer: profissionais que se dedicaram à preservação da memória material não se detiveram em registrar seus próprios percursos de trabalho. 
Esperamos assim- com nosso registro de procedimentos e reflexões, - contribuir minimamente para uma melhor compreensão futura do entendimento que os profissionais de hoje, desse final de milênio, tinham de suas práticas institucionais. Pouco importa, em certo sentido, se o que se fez será considerado pertinente ou equivocado. Importa, sim, deixar registrado, esclarecido, aquilo que se pretendeu. Sem esse procedimento básico não haverá como avançar nas discussões e releituras que futuramente se farão necessárias. Com essa preocupação gostaríamos de deixar registrada aqui, uma última consideração sobre a forma como esses trabalhos vêm sendo documentados no Museu Paulista.

Desde o início das atividades, em 1994, os trabalhos de intervenção têm sido registrados de modo não uniforme. Os objetos chegam ao Setor necessariamente acompanhados de uma requisição de trabalho com a assinatura do responsável pela sua guarda e de quem o recebe, assegurando, assim, o controle de sua localização no edifício. Imediatamente sua chegada é registrada em um livro de entrada do Setor de Têxteis e em relação semelhante no computador. O passo seguinte é a abertura de uma ficha de conservação para início dos trabalhos. E aqui começam as diferenças.

Idealmente todos os trabalhos deveriam ser documentados com uma ficha completa na qual constassem todas as informações sobre os objetos e, ao menos, uma fotografia de registro. Este seria o procedimento ideal, desejável, mas não é o que sempre acontece. Hoje, ao menos, podemos atribuir esta situação ao momento institucional que estamos vivendo: o acervo ainda em fase de cadastramento quase nunca chega ao setor de conservação acompanhado de informações sobre sua procedência, datação, materiais e outros dados documentais importantes a qualquer intervenção que se pretenda. Quase sempre parte-se do quase nada: quando há tempo disponível procura-se por uma 
informação aqui e lá; quando há tempo examina-se o objeto como sempre deveria ser feito: tecedura, identificação dos fios, torção, formas de costura, bordados etc. Mas na maioria das vezes isso acaba acontecendo apenas nos trabalhos de média e/ou longa durações. Esta contingência, portanto, termina determinando o volume de informações registrado nas fichas de trabalho. Da mesma forma acontece com a documentação fotográfica. Nos primeiros anos de atividade não havia no museu nem fotógrafo nem equipamento adeqüados aos registros de conservação. As imagens de registro acabavam sendo feitas por nós resultando, muitas vezes, em fotografias ou cromos de baixa qualidade isso quando não ocorria de todo um processo de trabalho se perder com a queima total de um filme etc.

Nos últimos anos, felizmente, esses registros têm melhorado em qualidade embora não tenhamos definido ainda um padrão único a ser mantido: às vezes o registro é realizado em cromo, às vezes em papel. A quantidade de imagens geradas também não está definida: se por um lado uma ou duas imagens pouco traduzem de um registro de intervenção, um maior número delas pode gerar um acúmulo muito grande de material documental a ser preservado pela instituição. Todavia é importante salientarmos que esta aparente indefinição ou ausência de padrões competentes de registro não se verificou apenas no setor de conservação de têxteis: é uma característica dessa instituição e de outros tantos museus brasileiros.

A falta de critérios definidos para registro e documentação visual de objetos históricos tridimensionais nos museus e centros de mémoria ainda é uma constante no Brasil.. Diferentemente das ciências exatas e biológicas onde há muito se definiram critérios de documentação, as ciências humanas - em especial a História - , não desenvolveram o hábito de trabalhar documentalmente seu acervo, embora teoricamente os chamados "estudos de cultura material" pensem 
fazê-lo. Áreas como Botânica, Medicina, Biologia, possuem tradição de registro fotográfico e desenho de suas coleções e objetos de estudo. As fotos de uma operação cirúrgica, de uma planta, uma célula, precisam sempre seguir padrões internacionalmente definidos. $\mathrm{O}$ mesmo ocorre com a aerofotogrametria e algumas áreas determinadas das ciências humanas. É o caso da Arqueologia e da Etnologia, por exemplo, que sempre tiveram claros os critérios de desenho e fotografação. Já a História, curiosamente tendo como elemento definidor $o$ estudo de documentos textuais, não se preocupou com a produção de registros iconográficos.

Centros de memória, como o Museu Paulista, possuem hoje, paradoxalmente ainda, duas abordagens bastante distintas em relação à imagem fotográfica: uma primeira, é a de preservação da imagem fotográfica histórica, "antiga"; e a segunda, a documentalista, de registro cotidiano, assumidamente histórico, do trabalho de hoje para o amanhã. Na primeira abordagem, as imagens são trabalhadas de forma arqueológica, teoricamente coerente e consideradas como documento histórico. Já na segunda, são consideradas complementos, documentação acessória ou mesmo secundária. Seriedade, método e cientificidade marcam o trabalho com as imagens do primeiro grupo; incoerência, subjetividade e falta de qualidade marcam as imagens do segundo grupo.

E nesse contexto podemos incluir o Museu Paulista, cuja documentação fotográfica caracterizou-se, como já afirmamos, pela descontinuidade e falta de critérios e padrões definidos ${ }^{185}$.

No Museu Paulista, até a década de 1960 - curiosa e historicamente compreensível -, só haviam sido documentadas fotograficamente as coleções de

\footnotetext{
${ }^{185}$ Nunca é demais reiterarmos que definimos documentação fotográfica, neste texto como aquela produzida para fins de registro documental, interno da instituição.
} 
pintura de cavalete. Todas as outras tipologias de objetos nunca foram documentadas enquanto coleções; eventualmente, para fins de publicação, uma ou outra "fatia" do acervo foi fotografada. Dentre o conjunto de fotografias podemos verificar falta de critérios e qualidade técnica. As fotos em sua maioria são frontais, sem escala e quando coloridas nunca apresentam escala cromática ou regra de referência.

A fotografia de conservação/restauração no museu seguiu a mesma falta de critérios verificada na área de documentação. As poucas imagens existentes nos 100 anos de atividade do Museu Paulista são aleatórias, diríamos: são flashes de problemas: furos, rasgos, partes faltantes, que nunca remetem ao objeto como um todo e muitas vezes não trazem qualquer identificação ${ }^{186}$. $\mathrm{Na}$ área de conservação de têxteis não se verificou nada muito diferente. Os estudos de caso apresentados, por exemplo, possuem documentação fotográfica bastante diferenciada, sem padrão definido. Essas preocupações nos foram surgindo com o passar do tempo e se acentuaram, na verdade, durante o projeto de conservação citado da Jaqueta de músico da banda Casa de Savóia, 1905, pertencente ao Museu Histórico de São Caetano do Sul. A jaqueta utilizada como japona, em péssimas condições de conservação, precisou ser trabalhada, mudou de formato e sofreu acréscimos de suporte da ordem de $30 \%{ }^{187}$. Das

186 No caso de uma liteira por exemplo:encontra-se uma foto de uma área com desprendimento de policromia, sem qualquer referência e indicação que lhe atribua sentido. Outra característica - justificada em parte pela falta de recursos financeiros,- são as fotos da "mágica", ou seja: uma foto do ANTES e uma foto do DEPOIS a atestar o grande feito do restaurador. As fotos do DURANTE, do registro de transformação do objeto, simplesmente inexistem. E assim continuam sendo produzidos dezenas de registros bem intencionados, mas sem critérios; equívocos, do ponto de vista documental.

187 Já na fase de documentação inicial, a fotografação não foi eficaz para registrar quatro tipos diversos de recosturas, em diferentes tonalidades de cinza, em áreas de difícil acesso como mangas internas e região inferior das axilas, tendo sido necessário recorrer ao desenho exaustivo dos problemas. Cabe esclarecer que a cor preta do casaco aumentou o grau de dificuldade dos registros fotográficos. O maior problema, todavia, surgiu durante o processo. verificamos ser quase impossível registrar aquilo que, por definição, deve ser "invisível". Os novos tecidos e costuras aplicados são quase imperceptíveis ao espectador 
dificuldades em registrar satisfatoriamente os trabalhos, adveio a questão sobre a

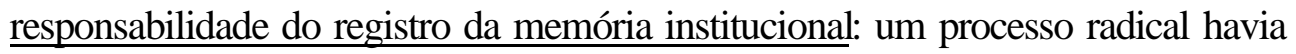
sido realizado sem ser competentemente registrado, apenas insinuado. Mas será que o registro "indutivo" é suficiente ?. Não estaríamos assim forjando uma memória e trabalhando com um excesso de representações ? Será que essa “documentação" realmente documenta alguma coisa, será que ela faz sentido? E se ela não faz sentido não estaríamos apenas, mais uma vez, adotando um procedimento politicamente correto que talvez nada acrescente ?

Em nosso entender seria fundamental que as instituições repensassem seus critérios de fotografação aproveitando-se da experiência de outras áreas de conhecimento como a Botânica, a biologia marinha, a citologia e a cirurgia médicas, que desde o início do século seguem regras e métodos bastante específicos de fotografia e desenho. Com isso poderíamos garantir padrões de qualidade de informação e documentação dos objetos e evitar gastos inúteis na produção e guarda de registros vazios de sentido.

comum; como então fotografá-los ? Assim os poucos slides produzidos apenas induzem ao registro da atividade desenvolvida, mas não a mostram. 


\section{capitulo 4}

\section{reflexões possíveis sobre um trabalho em construção}

Com certeza há alguns quebra-cabeças maravilhosos, alguns fenômenos em que as coisas parecem ser de um jeito, e depois você tem bons indícios de que não são do jeito que parecem ser. O que me fascina nisso é que existe uma boa norma prática, uma boa estratégia a adotar sempre que a ciência chega a um ponto de estagnação: encontre a asserção sobre a qual todos estão de acordo; negue-a e provavelmente você rompe a verdade auto-evidente, que acaba por revelar-se falsa, apesar de autoevidente. Devemos sempre procurar paradoxos, porque 
eles tendem a constituir-se em rupturas, em avanços científicos significativos. ${ }^{188}$

Todas as atividades desenvolvidas e reflexões decorrentes de nosso trabalho em conservação de têxteis- em parte narradas neste ensaio -, bem como o próprio ensaio, nasceram e se viabilizaram dentro de um contexto específico e restrito: a Universidade de São Paulo. Uma vez que teoria e prática foram já abordadas, gostaríamos neste último capítulo de considerar as eventuais especificidades do trabalho de conservação neste contexto determinado, se é que elas existem, apontando seus limites de atuação e de avaliação críticas.

\section{De rerum natura: a conservação e a USP. ${ }^{189}$}

Nas primeiras páginas deste ensaio destacamos a idéia de que no Brasil ainda prevalece a preservação da cultura material em suportes tradicionais e hierarquicamente valorizados: arquitetura, pintura, escultura e mobiliário ainda hoje são mais valorizados enquanto manifestações culturais do que todas as outras variáveis possíveis. Tal valoração- maior ou menor dos artefatos e imóveis, ainda que não necessariamente ideológica, - acompanha as regras do mercado de arte: a cultura material é pensada como capital, como valor que se valoriza. E tal visão predominante, sem dúvida, influenciou e ainda influencia as diretrizes de ação dos orgãos preservacionistas e, conseqüentemente, das atividades de conservação/restauração no país, ou seja: o termo patrimônio

\footnotetext{
${ }^{188}$ Daniel C. Dennett, entrevista. IN: Wim Kayzer MARAVILHOSA OBRA DO ACASO: PARA ENTENDER NOSSO LUGAR NO QUEBRA-CABEÇA CÓSMICO. Rio de Janeiro, Nova Fronteira, 1998, p.45.

189 De rerum natura (sobre a natureza das coisas) aludindo aqui ao poema de Lucrécio, editado por Cícero c. 70 AC.
} 
cultural, ironicamente na prática preservacionista relaciona-se diretamente com valores financeiro-comerciais.

Tudo indica que no Brasil os museus reproduziram tal valoração, principalmente no que diz respeito à conservação das coleções. A valoração de mercado, nas instituições, tratou de priorizar determinados grupos de acervo em detrimento de outros. E nesse mesmo raciocínio, laboratórios de conservação foram criados, sempre, para atender às mesmas categorias de bens culturais ${ }^{190}$. É estranho constatarmos que ainda hoje, institucionalmente, inexistam laboratórios formalmente especializados na conservação de metais, de couros e peles, de plumária, de instrumentos musicais, mecanismos etc. E mais estranho, ainda, é constatarmos que o mesmo aconteceu e acontece aqui dentro da Universidade de São Paulo. Mas qual a razão de insistirmos com a mesma valoração de décadas atrás? Por quê esse pensamento persiste dentro das instituições universitárias? Não seria de se esperar que a Universidade, justamente ela, trabalhasse sobre uma outra hierarquia de valores? ${ }^{191}$ Afinal o que limitou ou não propiciou o surgimento de outras especialidades da conservação?

Aparentemente tal situação na Universidade apenas refletiu o que ocorrera fora dela. Afinal como exigir especializações profissionais se elas não eram oferecidas no país e ninguém se preocupava em tê-las ? Ou talvez, ainda, -se preocupassem os profissionais de museus-, para quê serviriam especialistas

\footnotetext{
${ }^{190}$ Dentro dessa valoração foram organizados os poucos cursos de restauração no país que buscavam, a priori, formar profissionais para trabalhar na preservação da arquitetura, pintura, escultura, madeira e, bem posteriormente, papel. Curiosamente este movimento que no Brasil acompanhou uma valoração estrangeira do mercado de arte, não foi necessariamente verificado nos museus grandes, instituições de pesquisa e/ou universidades euro-americanas que trabalhavam com outra escala de valores e atribuições de juízo.

${ }^{191}$ Toda vez que neste texto estivermos falando dos museus da Universidade estaremos nos referindo apenas ao Museu de Arqueologia e Etnologia, Museu de Arte Contemporânea e Museu Paulista. Salvo quando mencionado, não estaremos incluindo, na expressão, o Museu de Zoologia .
} 
na conservação/restauração de tipologias que "pouco interessavam", que raramente eram e são expostas? ${ }^{192}$

Vejamos algumas idéias que o grupo de conservadores da Universidade fez publicar em edição recente:

“A Prática da Conservação na Universidade

A preocupação com a conservação dos acervos científicos aparece já descrita em 1896, nos relatórios do cientista Herman von Ihering, diretor do Museu do Estado, futuro Museu Paulista. Funcionalmente é o profissional zelador, o responsável pela limpeza e conservação das coleções. Apenas com a reforma administrativa de 27/12/1946 é que se cria o cargo conservador de museu, diretamente ligado ao diretor. Oficialmente, entretanto, a figura do conservador, no Ipiranga, aparece mencionada apenas no relatório da instituição de 1950. Sabe-se, também, que a orientação deste profissional e seu atelier de trabalho foram coordenados pelo restaurador Edson Motta, que veio do Rio de Janeiro com essa incumbência. O mesmo aconteceria, na década de 1960, quando ele retorna a São Paulo para organizar o laboratório de conservação de papel.

É na década de 1970, entretanto, que os museus se preocupam em organizar suas atividades de conservação, porquanto os acervos se encontram numa etapa de expansão e novas teorias museológicas e de restauro são implementadas no âmbito internacional. Tal iniciativa deve-se muito ao empenho pessoal dos intelectuais que assumiram a direção dessas unidades no período, inexistindo ainda órgãos centralizadores das políticas adotadas.

\footnotetext{
${ }^{192}$ É muito comum encontrarmos dificuldades para justificar a um visitante estrangeiro, por exemplo, porquê não expomos nossos acervos de plumária.
} 
Uma das primeiras atuações sistemáticas na área de conservação ocorre no MAE. O restaurador Carlos Régis Leme Gonçalves é contratado para organizar as atividades de conservação e restauração, implantar um laboratório e definir um perfil de carreira, que foi vigente nos museus até a recente reforma administrativa (1995).

A prática dessas atividades, entretanto, dada a autonomia das unidades, obedece a critérios próprios visando atender as necessidades prementes dos acervos, inexistindo interação entre as unidades. As posturas metodológicas e os critérios de intervenção sobre os objetos sempre foram determinados, na verdade, pela formação individualizada de cada profissional, realizada em cursos de formação no país e no exterior.

Precisamos definir enquanto universidade qual a nossa postura em relação às coleções. O que queremos preservar, afinal? Por que queremos fazê-lo ? Quais os critérios que norteiam, hoje, os trabalhos da USP em relação ao patrimônio cultural ${ }^{193}$

${ }^{193}$ Embora apresentado como um texto de autoria coletiva, a redação das diversas partes da publicação foi realizada por diferentes profissionais. O trecho acima foi escrito por nós em conjunto com Mariana Vanzolini e Regina Tirello, tendo sido 'editado' significativamente . O texto, já com outra autoria (?), prossegue nos seguintes termos:

"Projetos que Avançaram Dentro de um quadro descontínuo de ações em prol da proteção e gestão qualificada dos bens culturais da Universidade, a criação da Comissão de Patrimônio Cultural, em finais de 1986, e da Coordenadoria de Museus, em 1995, em muito avançaram, significando o início da discussão centralizada, por parte de especialistas e responsáveis pelos acervos, dos problemas relativos à conservação e das questões que envolvem o patrimônio da USP. Têm com sua atuação, ao longo destes anos, procurado caracterizar a noção da abrangência deste patrimônio com iniciativas como a criação de um banco de dados sobre patrimônio cultural.

Perante os esforços de instituições isoladas é que a Comissão de Patrimônio Cultural e a Coordenadoria de Museus podem vir a ser órgãos fundantes para uma reflexão da política universitária de proteção dos acervos da Universidade de São Paulo: as parcerias entre os museus e outras unidades da USP, a discussão mais ampla de uma política de acervos e um diagnóstico claro e preciso das reais condições do patrimônio universitário podem se transformar, a longo prazo, em uma ação efetiva baseada em uma nálise racional, sendo o presente trabalho da comu idade de restauradores uma formalização de tais intenções." CONSERVAC̄̃̃O E RESTAURO I Recomendações e projetos em Andamento na Universidade de São Paulo. Introdução. São Paulo: Comissão de Patrimônio Cultural/USP, 1996 , p. 9-12. 
Uma questão importante, apontada no texto, é a da inexistência de um projeto claro para a área de conservação dos bens culturais da Universidade, noção que ali extrapola os acervos dos museus. As ações e decisões, aparentemente, continuam sendo iniciativas individualizadas dos profissionais que governam as instituições. Mas será que isso é suficiente? Será que isso é profissionalmente competente enquanto prática institucional? É inegável que ocorreram avanços. A gestão anterior da Universidade, finalizada em 1997, por exemplo, assumiu questionando se a USP precisava e deveria conter museus; a gestão atual, contrariamente, fez do incentivo aos museus um dos ítens de sua plataforma ${ }^{194}$. Se este fato isolado nada garante quanto à prática administrativa que virá, ele sem dúvida é bastante significativo e 'novo' como conteúdo de uma plataforma política universitária.

Mas voltando à questão anterior. Será que a Universidade sabe o que está fazendo ou pretendendo, e para quê ? Como nós, na qualidade de Universidade, pretendemos administar o patrimônio? Quais os nossos critérios, a nossa definição de importante? Não seria desejável, para não dizer esperado, que da Universidade surgissem debates sobre a função de seus museus neste final de milênio? Será que não é hora de repensarmos seriamente nossas práticas institucionais, justamente agora quando se discute a criação de mais um museu na Universidade, o Museu de Ciências ? Quais as idéias que norteiam o projeto e qual a expectativa sobre uma iniciativa como esta? Qual o modelo internacional que vem servindo de base à execução do projeto? Para quê um Museu de Ciências? ${ }^{195}$ Será que temos estas respostas?

Este ensaio, como um todo, apresentou uma série de idéias extraordinárias e de questionamento das práticas e ideário preservacionistas

\footnotetext{
${ }^{194}$ A gestão atual, iniciada no ano de 1997, tem como reitor o Prof. Dr. Jacques Marcovitch. A anterior teve como reitor o Prof. Dr. Flávio Fava de Moraes.
} 
encontradas inclusive na Universidade de São Paulo, inclusive em nossa prática cotidiana de trabalho. Causa-nos estranheza, sempre, o discurso consensual e romântico que ainda vige na Universidade em relação aos bens culturais: os binômios preservação/destruição, bom/mau, favorável/desfavorável, parecem reger todo o ideário praticante. $\mathrm{O}$ ponto central das discussões está sempre no mérito da intenção e jamais no conteúdo da ação. Não será que diferentemente do ocorrido em todas as outras áreas do conhecimento representadas nesta Universidade - onde toda sorte de releituras se verificaram nas últimas décadas -, as áreas de museologia e conservação continuaram apenas repetindo o que sempre existiu, quase sempre tão antigo? Talvez seja hora de pensarmos um pouco, de pensarmos diferente e simples, de ampliarmos a mesma discussão de sempre, já tão restrita. Não se trata de defender o final disso ou aquilo, de destituir as importâncias: trata-se, apenas, de repensar ao invés de apenas repetir e prosseguir repetindo. Nossas idéias de século XIX estranhamente convivem, hoje, com teorias como a da ressonância mórfica ${ }^{196}$ e outras tão inovadoras quanto; mesmo na Universidade. Será que isso é indicador de alguma coisa ? Aparentemente vivemos numa geografia em que as idéias aparecem quase sempre de forma arrogante e pioneira e depois caem no esquecimento, sem nada acrescentar àquilo que já existia. Será que nossas "verdades auto-evidentes" e nossas práticas institucionais sobreviveriam a uma avaliação conceitual séria?

Cabe aos museus da Universidade promover tais discussões e incentivar as pesquisas nas áreas de museologia e conservação; estranhamente não é o que

\footnotetext{
195 Não se trata aqui de julgar o mérito da iniciativa, mas de compreender o que se pretende. 196 A impressionante teoria da ressonância mórfica da autoria do bioquímico Rupert Sheldrake - cuja fala tive a sorte de ouvir ao acaso em Cambridge, no início de 1998 -, muito questionada no meio científico (diz-se que ou Sheldrake revolucionará todo o conhecimento científico desde Einstein ,ou será lembrado como o maior charlatão do século XX), afirma que coisas semelhantes influenciam as coisas semelhantes subseqüentes. No campo das idéias a teoria sugere que qualquer coisa aprendida por alguém hoje será mais facilmente aprendida por outro alguém amanhã, independentemente deles travarem contato de qualquer espécie. A teoria introduz, ainda, o princípio de que existe memória na natureza.
} 
se verifica. Continuamos trabalhando para nós mesmos, sem um para quê consistente, atualizado, como se a importância do que fazemos fosse certa e acima de qualquer crítica. $\mathrm{E}$ isso não nos parece sério, muito menos científico. Preservar o patrimônio jamais significou preservar as mesmas idéias sobre esse patrimônio!

\section{Conservando aqui, destruindo ali: científico, pero no mucho.}

Se um laboratório de conservação levar um ano examinando ou tratando um objeto importante, do começo ao fim sob uma iluminação de 750 lux, ele será responsável por um dano equivalente ao causado por meio século de exposição desse objeto sob luz. controlada. ${ }^{197}$

Outro ponto sobre o qual todos nós precisamos pensar, sobretudo nos museus universitários, é se realmente sabemos o que estamos dizendo quando falamos em preservação de artefatos. É inegável que os museus da USP, nos últimos anos, têm buscado aprimorar seu conhecimento e sua prática preservacionistas. Contudo, talvez mais uma vez pela inexistência de discussões e revisões necessárias, verifica-se cotidianamente a adoção de procedimentos "caricaturais" de conservação: o que deveria ser conhecimento aplicado transforma-se em regra mal utilizada, em equívoco e desperdício. Mas que procedimentos equivocados seriam esses?

Segundo afirmam os cientistas, a máquina é a grande metáfora deste século que termina. Passamos, segundo dizem, da metáfora orgânica para a

197 Stefan Michalski, The Lighting Decision IN:FABRIC OF AN EXHIBITION: AN INTERDISCIPLINARY APPROACH, Ottawa, 1997. Preprints. Ottawa, Textile Symposium 97, Canadian Conservation Institute, 1997, p.101. 
metáfora mecânica, para o maquinismo ${ }^{198}$. A máquina ter-se-ía tornado indispensável à nossa compreensão da natureza trazendo a ela associada, necessariamente, a idéia de avanço tecnológico e científico. Nosso cotidiano encheu-se de máquinas de todos os tipos sem que ao menos tenhamos reagido com estranhamento. Finalmente chegamos à era JETSON ${ }^{199}$ ! Essa interpretação do mundo equipado, sem dúvida, também envolveu os museus oferecendo inúmeras vantagens em diversas áreas: educação, difusão, segurança, pesquisa e..... conservação. $\mathrm{O}$ fato em si não representaria problema algum: como já discutimos anteriormente, a conservação-ciência pressupõe o uso de equipamentos.

A conservação pode dispor hoje de uma série de métodos de análise a lhe garantir maior segurança e eficácia na obtenção dos resultados pretendidos: fluorescência por raio-X, espectroscopia, endoscopia, reflectografia, termografia, difração por raio-X são apenas alguns exemplos ${ }^{200}$. Maior o número de análises, maior o grau de cientificidade "atribuída" a uma intervenção. Ignoremos momentaneamente a discussão anterior sobre o exagero; o ponto a discutir agora é outro.

Toda essa tecnologia a serviço da conservação é utilizada nos museus do hemisfério norte dentro de um quadro de coerência, ou seja: exagerados ou não, tais procedimentos de alto custo têm continuidade assegurada nas práticas

\footnotetext{
${ }^{198}$ Esta é uma idéia recorrente em autores como Oliver Sacks, por exemplo. Com referência a essa idéia vide as entrevistas e debate organizados por Wim Kayzer em MARAVILHOSA OBRA DO ACASO: PARA ENTENDER NOSSO LUGAR NO QUEBRA-CABEÇA

CÓSMICO. Rio de Janeiro, Nova Fronteira, 1998, 352p.

199 JETSON refere-se à série homônima, futurista, de desenhos animados produzida na década de 1960. Alguns autores como J.G. Ballard defendem a idéia de que o discurso ficcional das últimas décadas foi tão vigoroso que retirou do real todo o impacto científico e tecnológico sobre o nosso cotidiano. vide: Back to the Heady Future IN A USER'S GUIDE TO THE MILLENIUM, ESSAYS AND REVIEWS. London, Harper\&Collins, 1996, p. 192-194.
} 
subsequientes. Os investimentos realizados na conservação de um objeto para uma exposição temporária, por exemplo, nunca são comprometidos pelo próprio projeto de exposição temporária: mobiliário, iluminação, materiais a serem utilizados, segurança e pessoal especializado garantem que o objetivo principal seja alcançado: a preservação do artefato está garantida. No Brasil, na Universidade de São Paulo, quase nunca isso ocorre.

Façamos alguns paralelos com outras áreas de atividade. Uma emissora de televisão, por exemplo, dificilmente investiria em equipamentos sofisticados de geração de imagem sem investir igualmente em todas as demais atividades e pessoal envolvidos na geração dessas imagens, por saber que basta um elemento da rede não apresentar o mesmo nível de qualidade para que todo o investimento seja comprometido e seu objetivo não seja alcançado. A indústria têxtil no Brasil é outro bom exemplo: milhões de dólares são investidos em pesquisas, equipamento e pessoal para que seus objetivos sejam alcançados. Um só aspecto negligenciado pode colocar tudo a perder. $\mathrm{E}$ assim procedem todos aqueles que têm claros os objetivos de suas ações e sabem identificar toda a rede de fatores envolvidos para alcançá-los. E os museus ? Será que os que nele trabalham realmente compreendem o porquê de suas ações? Será que eles compreendem, afinal, o que significa conservação?

As práticas de trabalho na Universidade vêm sugerir que não, e muitos são os exemplos a citar. Uma única biblioteca apropriada seria suficiente para reunir todas as chamadas "obras-raras", por exemplo, e garantir sua preservação efetiva. Por quê este projeto aparentemente simples não se viabilizou? Há anos a Universidade financia a restauração de pinturas murais em um edifício que está caindo e que paradoxalmente abriga a pós-graduação da Faculdade de

\footnotetext{
${ }^{200}$ Para um quadro completo dos métodos analíticos e estruturais de investigação científica vide o livro de Marco Ferretti SCIENTIFIC INVESTIGATIONS OF WORKS OF ART. Roma, ICCROM, 1993, p. 3.
} 
Arquitetura. O Museu de Arqueologia e Etnologia a despeito de se encontrar instalado em um edifício precário, infestado por cupins, gatos e goteiras, optou por investir em novos equipamentos de armazenagem e controle ambiental . Não faz muito tempo o Museu de Arte Contemporânea teve uma nova sede especialmente projetada na qual, entre tantos outros problemas, não há espaço suficiente para guardar seu acervo, nem tão numeroso assim! As necessárias reformas no Museu Paulista não ocorreram sem trazer uma série de prejuízos às coleções: excesso de manuseio e transporte, excesso de sujeira sobre os objetos quase sempre causado pelo excesso de limpeza do edifício! Será que realmente

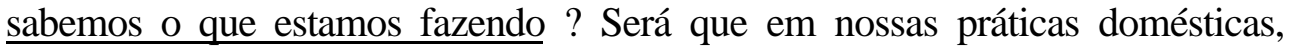
pessoais, agiríamos assim? Será que trocaríamos o carpete antes de consertar o telhado ? Será que manteríamos nossos livros prediletos espalhados em cantos úmidos e sujos ? Será que alugaríamos uma garagem na qual nosso carro não coubesse ? As respostas parecem bem evidentes. Não se trata aqui de buscarmos justificativas ou atribuir culpa; culpados somos todos: conservadores, curadores e diretores; uns por omissão ou preguiça, outros por negligência e arrogância. O que é preciso reafirmar, aqui, é que não existe conservação mais ou menos, meia-conservação, do mesmo modo como não existem pesquisas mais ou menos sérias ou gente meio-honesta.

Retomemos nossa primeira idéia neste tópico sobre os procedimentos caricaturais de conservação. Por procedimentos caricaturais entendemos, aqui neste texto, aqueles procedimentos equivocados que nada ou pouco contribuem à conservação das coleções, embora encantem visitantes, autoridades e não especialistas. Citemos alguns exemplos:

1. o uso de plástico bolha: o material plástico que conhecemos como plástico bolha é um dos materiais que mais sucesso fazem nos museus. Seu uso, assim como o dos plásticos em geral, é recomendado em determinadas situações desde 
que produzido com material adeqüado. Na verdade, no Brasil, consumimos indiscriminadamente com o nome de plástico várias matérias-primas diferentes; algumas, como o polietileno, são adeqüadas à conservação; outras muito pelo contrário.

O plástico bolha tem uma função bastante determinada: ele é um material de proteção anti-impacto e só. Sua utilização em outros contextos não faz sentido algum, é desperdício. Entretanto, em muitos museus, seu uso exagerado, indiscriminado, tornou-se indicativo de conservação, de cuidado, de atitude profissional : um museu sem plástico bolha não é um museu sério !

2. a embalagem rococó: a embalagem rococó é a embalagem exagerada, sempre muito bonita e carregada de detalhes e acessórios que nada acrescentam do ponto de vista da conservação: lacinhos de fita, fechos, alças, materiais importados etc. O mais grave é que, muitas vezes, elas costumam ser ineficientes não atendendo seu objetivos básicos de proteção e fácil acesso.

3. os armários deslizantes: os armários deslizantes, tão populares hoje para acondicionar coleções, possuem algumas vantagens evidentemente. Mas possuem muitas desvantagens também, sendo a pior delas a trepidação e movimentação excessiva e desnecessária de dezenas de objetos o que no caso de materiais cerâmicos, plumária, vidros e mesmo têxteis pode ser muito prejudicial a médio e longo prazos. Mas assim como nos casos anteriores, os novos mobiliários tornaram-se indicativos de boa conservação, de atualidade. $\mathrm{E}$ note-se que não estamos sequer discutindo o fato de que esses equipamentos não são protegidos com tintas adeqüadas como se faz no estrangeiro, e mesmo que em um clima úmido como o nosso a opção pelo metal pode não ser a escolha mais inteligente !

4. o microscópio: o microscópio é o grande indicativo, no Brasil, da cientificidade do trabalho executado. Entretanto poucos profissionais sabem 
trabalhar com ele, interpretar aquilo que veêm com exatidão. A microscopia, sem dúvida, é fundamental ao trabalho de conservação desde que ela seja corretamente interpretada. Mas será que é sempre assim ? Muito dinheiro tem sido investido em microscópios e outros tantos equipamentos. Será que sabemos o que fazer com eles? Tal qual o telefone celular, o microscópio é um instrumento de trabalho necessário para alguns e apenas um acessório para a maioria.

5. luvas e demais equipamentos de segurança. O uso de materiais de segurança nos museus ainda é bastante eventual. São vários os casos de intoxicação, alergias, danos à visão causados por fungos etc, recentemente na Universidade! Mais do que simples negligência, este mau hábito é uma questão cultural: no Brasil a idéia de segurança jamais foi levada a sério, em nenhuma situação. Consumimos produtos químicos perigosos, depressivos, material explosivo cotidianamente e de forma abusiva. Fuma-se em postos de gasolina, armazenam-se garrafas de álcool em todo e qualquer lugar, ingerimos diariamente o excesso de detergente que deixamos em nossos utensílios domésticos etc. A segurança é pensada ainda como um exagero, como um luxo ou preciosismo. E assim sendo por quê os museus seriam uma excessão ? Por quê a Universidade seria uma exceção ? Infelizmente, mesmo na Universidade, a idéia de segurança é uma questão legal no pior sentido: o sistema de segurança da Universidade trata apenas de protegê-la contra possíveis problemas de ordem legal e/ou trabalhista. Faz-se, apenas, o muito pouco exigido por lei.

Neste quadro seria surpreendente que aqueles que trabalham nos museus realmente compreendessem o porquê de determinados procedimentos e cuidados consigo e com os artefatos. Uma simples questão é um grande indicativo dessa situação: quantos de nós sabem operar um extintor de incêndio, uma operação que após treinamento é mais elementar do que usar um 
computador ? Qualquer pesquisa hoje na Universidade apontaria um resultado que não excederia os $5 \%$ de nós ! O que acaba ocorrendo então nos museus ? $\mathrm{Na}$ maioria das vezes o que encontramos são comportamentos ou hábitos caricaturais de segurança e limpeza: máscaras, luvas, óculos de proteção etc, são usados apenas sob pressão ou vigilância. Faz-se porquê sim ; não existe a noção de para quê.

Se do ponto de vista da segurança do trabalho as atitudes sob pressão resultam em algum benefício, do ponto de vista da conservação dos objetos raramente nota-se alguma vantagem. Vejamos por exemplo a recomendação quanto ao uso de luvas durante a manipulação de artefatos. Tal recomendação segue dois princípios básicos: proteger o objeto da gordura e sujidade das mãos e proteger o dono das mãos contra qualquer substância presente no objeto que possa ser nociva à saúde. Limitemo-nos aqui ao segundo princípio.

O uso de luvas de algodão é especialmente recomendado no manuseio de materiais porosos sob uma condição básica: elas precisam estar limpas. Contudo, a despeito da recomendação geral, é evidente que no caso de tecidos, cerâmicas e metais em decomposição, por exemplo, seu uso pode acarretar um dano ainda maior devido à aderência entre o suporte e o tecido da luva; isso deveria ser elementar. Para esses casos existe a opção por outro tipo de luvas ou mesmo por nenhuma luva. Uma vez mais voltemos ao paralelo com a situação doméstica: imaginemos que tenhamos que apanhar um caldeirão sem alça, há muito sobre o fogo. Qual o material que escolheríamos como intermediário entre o metal quente e nossa pele ? Será que algum adulto pensaria em usar uma luva de plástico ? É claro que não, porque ele saberia o que está acontecendo e do que precisa. Pois é, é simples assim. O problema é que nos museus as pessoas não sabem do que precisam porque não entendem o que estão fazendo (e espantosamente, em muitas operações isso se aplica inclusive 
aos conservadores). Paradoxalmente, principalmente em um museu histórico, é justamente essa proximidade com a situação doméstica que faz todos que lá trabalham acreditarem saber o que estão fazendo: esta é uma característica do contexto museológico universitário.

Dificilmente alguém na Universidade sugeriria a um biólogo a melhor forma de cuidar de um animal machucado ou discutiria com um engenheiro a respeito da quantidade de argamassa a ser utilizada em uma construção. Já quando falamos de museu todos parecem aptos a discutir. Não se trata aqui de defesa corporativa; acreditamos que esta talvez seja uma das causas a justificar tantos equívocos - maiores e menores,- já mencionados. Um músico talvez possa administrar um hospital melhor do que um médico o faria, por quê não? Dificilmente, entretanto, esse profissional aventurar-se-ía na execução de uma cirurgia. Por quê ? Porque ele como profissional reconhece o limite responsável de sua atuação, tem consciência daquilo que conhece e daquilo que não conhece. Já um médico talvez se atrevesse a substituir um maestro !

A reprodução de procedimentos estereotipados de conservação ainda é uma prática constante dos museus; mais do que um momento dentro de um processo de amadurecimento, digamos, ela é uma tendência. Questões como a apontada por Stephen. Michalski na citação que inicia este tópico são comuns e nem sequer são percebidas. Existe uma grande hipocrisia e uma grande ignorância no comportamento de trabalho dos museus em relação à conservação das coleções. Tentamos exibir uma preocupação que não existe de fato: o nosso exagero, quando existe, quase sempre é equivocado! Quando se entende de tudo não se procura aconselhamento pois tudo é considerado uma obviedade. E talvez anos de trabalho pautados em "obviedades" sejam os 
responsáveis por tantos equívocos, por tanta perda de tempo na gestão dos bens culturais da Universidade de São Paulo. ${ }^{201}$

\title{
3. Limites de atuação e crítica: a opção pela Universidade.
}

\begin{abstract}
E se um dia ou uma noite um demônio se esgueirasse em tua mais solitária solidão e te dissesse: "Esta vida, assim como tu a vives agora e como a viveste, terás de vivê-la ainda uma vez e ainda inúmeras vezes; $e$ não haverá nela nada de novo, cada dor e cada prazer e cada pensamento e suspiro e tudo o que há de indizivelmente pequeno e de grande em tua vida há de te retornar, e tudo na mesma ordem e seqüência - e do mesmo modo esta aranha e este luar entre as árvores, $e$ do mesmo modo este instante e eu próprio. A eterna ampulheta da existência será sempre virada outra vez e tu com ela, poeirinha da poeira!" - Não te lançarias ao chão e rangerías os dentes e amaldiçoarias $o$ demônio que te falasse assim? Ou viveste alguma vez. um instante descomunal, em que lhe responderias: "Tu és um deus, e nunca ouvi nada mais divino!".

Se esse pensamento adquirisse poder sobre ti, assim como tu és, ele te transformaria e talvez te triturasse; a pergunta, diante de tudo e de cada coisa: "Quero isto ainda uma vez e ainda inúmeras vezes?" pesaria como o mais pesado dos pesos sobre teu agir! Ou então, como terias de ficar de bem contigo mesmo e com a vida, para não desejar nada mais do que essa última, eterna confirmação e chancela ?
\end{abstract}

\footnotetext{
${ }^{201}$ Muitas vezes quando se busca aconselhamento de conservação, procura-se por outros especialistas de áreas com credibilidade. É inacreditável como a antiga valoração das áreas de exatas e biológicas como as únicas realmente sérias é poderosa dentro do imaginário da própria área de humanidades. Um químico tolo ou um engenheiro arrogante receberão mais atenção nos museus, por exemplo, do que qualquer conservador. Talvez isso ocorra por eles serem todos ainda bastante jovens, imaturos ou mesmo limitados em seu conhecimento. Mas será esta a principal razão?

${ }^{202}$ Este trecho da Gaia Ciência de Nietzche foi copiado da transcrição existente no início do texto O eterno retorno do mesmo: Tese cosmológica ou imperativo ético ? de Scarlett Marton, a quem agradeço por várias indicações valiosas, aqui e do outro lado do mundo. Vide: ÉTICA, op. cit. p. 205.
} 
Trabalhar na Universidade de São Paulo para muitos é apenas contingência ou acaso; para outros é opção. Talvez, como já afirmamos em outra ocasião, nada haja de objetivo nesta escolha: talvez a USP e todas as universidades mundo afora sejam apenas o refúgio natural daqueles indivíduos que não sobreviveriam no mundo financeiro-competitivo; talvez não. Quem sabe as universidades também representem algo de muito bom, de importante, uma fatia necessária do mundo a partir da qual ainda é possível enxergar-se a vida como espetáculo, tal qual num palco circular, shakespeareano, onde todos os elementos estão à vista daqueles que se interessem por olhá-los em suas muitas $\operatorname{possibilidades}^{203}$.

Este ensaio, acreditamos, encerra um projeto de trabalho: a introdução de uma atividade de conservação inexistente na Universidade de São Paulo. Independentemente do rumo ou encaminhamento que as atividades de conservação de têxteis no Museu Paulista venham a seguir, elas acontecerão, então, dentro de um novo contexto, serão já um outro projeto. Procuramos discutir neste texto, na medida do possível, as idéias que dominaram as práticas cotidianas, práticas essas que vieram se modificando com a experiência e as questões advindas do trabalho realizado. Contudo apesar dos encaminhamentos metodológicos terem sido registrados, sempre, desde o início dos trabalhos- quer na documentação específica quer em publicações e outras divulgações institucionais -, a verdade é que prática e discurso foram construídos sempre sem contraponto de nenhuma natureza, por um único e mesmo interlocutor ${ }^{204}$.

\footnotetext{
${ }^{203}$ Esta metáfora do palco shakespeareano, em oposição ao palco com proscênio, é utilizada em outro contexto por Stephen Toulmin, filósofo da ciência, na sua discussão entre consciência e mente. vide WIM KAYSER, op.cit.

204 Referimo-nos, aqui, exclusivamente à falta de interlocutores em nossa área de especialidade no Brasil. Muitas questões podem e são discutidas com Luciana da Silveira, do Rio de Janeiro, cuja atuação entretanto é bastante diferenciada já que a profissional trabalha em atelier particular como prestadora de serviços de conservação a museus. Nestes anos, todavia, vários profissionais de áreas próximas compartilharam nossas questões e
} 
Por mais que se deseje e se tente, todo e qualquer discurso torna-se sujeito a desgastes e contradições sérias de forma e conteúdo durante o desenvolvimento de um processo. Por maior que seja o empenho em enxergar por todos os lados, como sugere a imagem do palco shakespeareano, a proximidade excessiva necessariamente dilui o foco da atenção impedindo, muitas vezes, uma auto-crítica consistente. Afinal, será que todo esse trabalho fez algum sentido ? Será que ele realmente importa ?

A despeito de todas as críticas possíveis e pertinentes o projeto analisado não faria sentido algum em qualquer outro contexto que não fosse a Universidade de São Paulo. A USP é uma das poucas instituições no país e mesmo fora dele a propiciar e viabilizar projetos de autoria individual nos moldes pretendidos e a comportar sua expansão e continuidade. Nesse caso específico a oportunidade ficou e continua evidente. Dificilmente em algum outro contexto nacional e mesmo estrangeiro um projeto como esse teria conseguido tanto apoio e atenção: o nome Universidade de São Paulo e sua infra-estrutura foram sem dúvida alguma as bases necessárias a tudo que se organizou, mesmo se considerarmos que esse tudo seja ao mesmo tempo muito pouco. Em nenhum outro contexto institucional teríamos assegurada a extensão de nossas atividades à outras instituições, a orientação sistemática de novos profissionais incentivada, a oportunidade de buscar, desenvolver e propor outros parâmetros de atuação e pesquisa específicas, sem que tudo isso se configurasse em trabalho extraordinário, em trabalho a mais (isso sem mencionar, ainda, as possibilidades de intercâmbio e assessoria com profissionais do estrangeiro). As perspectivas de

dúvidas, oferecendo um amparo importante: Ricardo Bogus, Regina Tirello, Marilúcia Bottallo, Adriana Mortara Almeida, Renato Brancatelli, Álvaro Guimarães dos Santos. Mencione-se, ainda, a enorme contribuição trazida pelos jovens profissionais que estagiaram e estagiam conosco: Cristiane Ceskanauskas, Ana Cláudia Vibancos, Luciana Martins Costa, Maria Cláudia Alcântara, Joelma Leão, Rita Andrade e Rafael Celidônio. 
trabalho na USP nas áreas de conservação podem ser melhores do que em qualquer outra instituição do país; basta que saibamos construí-las com competência e conduzílas para um trabalho de importância. Curiosamente, entretanto, se todas essas condições favoráveis de trabalho por um lado geram entusiasmo- nos termos já definidos neste trabalho -, por outro geram uma preocupação constante com e sobre aquilo que se pretende realizar.

A fala do demônio no texto de Nietzche, citada no início deste tópico, acrescenta um argumento importante a esta discussão ${ }^{205}$. A aparente positividade detectada no desenvolvimento de nossas atividades vem sugerir que o mesmo projeto, caso fosse iniciado hoje ou amanhã- e se nos fosse permitido optar ou não pelo retorno do mesmo, - teria em linhas gerais as mesmas características deste já implantado. Algumas mudanças circunstanciais e atualizações deveriam ocorrer, evidentemente, mas de um modo geral o trabalho desenvolver-se-ía nos mesmos moldes da experiência anterior. As atividades afinal se desenvolveram de uma forma muito mais satisfatória do que o esperado, embora questões como o aumento considerável da coleção de objetos têxteis, é verdade, não tenham sido equacionadas nas proporções em que ocorreram. A aparente solidez da atividade, seu reconhecimento interno, no meio museológico e mesmo no estrangeiro superaram as previsões mais otimistas. Felizmente ou estranhamente, não há o que lamentar no percurso realizado. Portanto a pergunta a ser feita agora não é se as atividades devem continuar, pois tudo indica que sim, mas de como e para quê devem continuar.

Construir essas respostas, por sua vez, exige que pensemos sobre dois pontos em especial: o primeiro diz respeito à(s) forma(s) de se aprimorar a médio e longo prazos alguns procedimentos de trabalho, incorporando algumas das idéias expostas ao longo deste texto; o segundo seria refletir sobre o perfil 
profissional mais adequiado às atividades de conservação na Universidade, compreendendo aqui não só aquele perfil que desejamos para nós mesmos mas, principalmente, aquele que gostaríamos de ver acompanhando nossos futuros profissionais. A palavra-chave agora parece ser continuidade.

Tudo indica que o politicamente correto hoje já tenha invadido boa parte do pensamento, dos trabalhos e da atitude da Universidade de São Paulo nas mesmas proporções e intensidade verificados fora dela. Da administração aos esportes, das salas de aula aos museus somos todos reprodutores dessa tolice fim de século. Pensando nesses termos, nada mais natural que o trabalho de conservação na Universidade tenha tomado esse rumo. Em nosso caso específico, como já discutimos nos capítulos anteriores, a adesão foi quase irrestrita. Será possível rompermos com um entorno tão vigoroso, tão estabelecido de influências ? Será possível construir um trabalho diferente ? Talvez apenas uma postura pautada num auto-engano ${ }^{206}$ temporário, instrumental, possa viabilizar uma perspectiva de mudança.

O trabalho de conservação de têxteis no Museu Paulista tem, por contingência, delineado determinadas posturas profissionais esquisitas. O fato do trabalho ser coordenado por uma especialista não filiada a nenhuma das associações profissionais existentes no Brasil e no estrangeiro - apesar de ainda causar estranhamento-, aos poucos vai sendo compreendido enquanto mensagem: o que existe, do modo como existe, não nos interessa. Quer se queira quer não, esse comportamento tem influenciado outros profissionais e

\footnotetext{
205 A citação, neste texto, é apenas uma ilustração. O contexto original da citação na Gaia Ciência aqui não importa .

${ }^{206}$ Auto-engano aqui entendido nos termos desenvolvidos por Eduardo Gianetti: “O que aconteceria se o auto-engano fosse inteiramente banido da existência e da convivência humanas? Como seria viver num mundo em que a verdade objetiva prevalecesse sempre? Um mundo em que ninguém jamais se enganasse a si mesmo (local) ou sobre si mesmo (global)?....A crença de que conseguiremos realizar muito (ou o impossível) é muitas vezes a condição necessária para que realizemos pelo menos um pouco (ou o possível).." AUTO-ENGANO, op.cit., p. 56 e 61.
} 
talvez possa, a longo prazo, construir uma situação peculiar. Não se trata de lutar contra mas de defender um outro padrão profissional: trabalhar e parecer trabalhar são coisas bastante distintas. Todos sabemos o conteúdo promocional e pouco profissional das associações no Brasil: quase sempre o trabalho sério na área de conservação aqui e mesmo no estrangeiro, acontece longe das politicagens dos colóquios e seminários patrocinados com e para os mesmos profissionais de sempre, muitas vezes instalados já dentro das agências financiadoras ${ }^{207}$. Este comportamento "distante" entretanto jamais significou isolamento. O número de assessorias solicitadas, assim como o atendimento a todo e qualquer profissional que solicitou estágio ou qualquer outra forma de cooperação, vêm comprovar a possibilidade de trabalharmos com outros parâmetros e sugerir, também, uma direção a ser seguida.

Talvez a maior dificuldade mesmo esteja em estabelecer-se algumas mudanças internamente, no Museu Paulista e na Universidade. Com grande facilidade idéias como a do exagero e do comportamento politicamente correto nos museus, por exemplo, podem tornar-se justificativa do não fazer nada, do fazer menos e do desfazer. O não fazer nada, o fazer menos e o desfazer, nesse caso, podem tornar-se posturas legítimas desde que se apresentem como produto de propostas consistentes de trabalho e não como um oportunismo de ocasião. A busca de uma prática diferenciada e teoricamente consistente apresenta-se, assim, como a melhor opção e o maior desafio a médio e longo prazos.

Toda e qualquer chance de mudança futura, seja das práticas seja das idéias, está associada necessariamente ao surgimento de novas oportunidades de educação e formação profissionais. Dificilmente alterações significativas na área de conservação ocorrerão nos museus da Universidade, enquanto não contarmos

${ }^{207}$ É evidente que existem excessões, que pelo Brasil afora vários profissionais insistem em 
com cursos sistemáticos de especialização e programas de estágio. O formato dessas atividades, sem dúvida, necessitará ser estudado e amplamente discutido, mas sua criação deve ser seriamente considerada. O ideal seria contarmos com uma formação básica que pudesse ser desdobrada, em seguida, nas diferentes especialidades possíveis. Assim, numa segunda etapa, o aprendizado já direcionado poderia ter prosseguimento nos diferentes museus nos moldes,talvez, do trabalho realizado entre a Royal School of Art e o Victoria \& Albert Museum em Londres ${ }^{208}$.

Os estágios oferecidos no Museu Paulista desde 1994 têm oferecido resultados bastante positivos. Neles os interessados desenvolvem um projeto de trabalho em conservação em todas as suas etapas: pesquisa histórica, pesquisa bibliográfica, caracterização da tipologia e dos materiais, documentação, possibilidades de intervenção, projeto de acondicionamento etc. No planejamento dessas atividades entende-se que tanto os trabalhos do Museu na área quanto o aprendizado do estagiário avancem num ritmo paralelo, articulado e mutuamente vantajoso. ${ }^{209}$ Além deste trabalho específico os estagiários acompanham outras atividades do setor e participam de atividades externas como as diversas edições da exposição Labirinto da Moda, por exemplo.

Se resultados tão satisfatórios têm sido obtidos em um programa informal, diríamos, e orientado por um único profissional, imagine-se o resultado que poderíamos obter caso envolvêssemos outros especialistas da Universidade

\footnotetext{
lutar para que essas associações se tornem representativas, competentes e profissionais.

${ }^{208}$ Nestas instituições poucos alunos são admitidos anualmente, cerca de um ou dois por especialidade. Após um núcleo comum de aprendizado os estudantes passam a estudar e desenvolver um projeto de trabalho nos laboratórios do museu sob orientação direta e constante de um profissional.

${ }^{209}$ Neste ano de 1998 quatro projetos estão em andamento: 1. Estudo de caso: Traje Samurai do século XVII, por Rafael Celidônio; 2. Estudo de coleção: mantas e xairéis, por Joelma Leão; 3. Estudo de coleção: luvas e mitenes, por Rita Andrade; 4. Estudo de Caso: Traje de Anjo do século XIX, por Cláudia Alcântara.
} 
e do estrangeiro! A atividade de conservação no Brasil ainda é uma atividade de poucos e isso precisa mudar: a Universidade de São Paulo tem toda a infraestrutura necessária ao desenvolvimento desse centro de formação que teria por endereço natural a Escola de Comunicações e Artes. Por que não ?

Hoje o trabalho de conservação de têxteis em São Paulo ao menos, encontra-se num momento no qual ainda é imprescindível que outros profissionais viagem ao exterior para se especializarem nesta área e outras correlatas como história do tecido e da indumentária, por exemplo. Uma vez constituído um pequeno grupo de profissionais que seja, teremos assegurada a continuidade do trabalho institucional. Temos tudo por aprender e pesquisar, ainda e o Museu Paulista, repetindo o que afirmamos acima, é a instituição apropriada, o endereço natural ao desenvolvimento dessas atividades. Juntos, curso de formação e trabalho institucional poderão introduzir novos parâmetros de trabalho àqueles interessados que agora pouca escolha têm, garantindo também, quem sabe, a renovação das práticas e idéias tão cansadas de hoje.

Falta-nos, finalmente, considerar o perfil profissional que gostaríamos de incentivar. Acreditamos que as diversas especialidades da conservação requeiram determinadas especificidades. No caso dos têxteis o perfil ideal, diríamos, viria de uma mistura $70 \%$ conservador-cientista e $30 \%$ restaurador artista, nos termos definidos anteriormente neste ensaio. De modo algum deveríamos incentivar o modelo norte-americano, do conservador quase virtual; ao mesmo tempo não precisamos incentivar a formação de restauradores criativos pois eles sempre existirão, longe dos cursos e universidades. Sem dúvida alguma os diversos modelos de formação profissional europeus são bem mais interessantes tanto do ponto de vista teórico quanto do prático. Em termos metodológicos, acreditamos, parece ser mais sadio incentivarmos possibilidades 
diversas, múltiplas e mesmo antagônicas. A opção única, exclusiva, é redutora e perigosa por definição.

Prioritário talvez seja optarmos por um perfil inteligente de profissional, por indivíduos dispostos a reconsiderar e renovar sempre aquilo que se mostra como certeza, como auto-evidente. Incentivar a formação de profissionais nos moldes em que ela acontece hoje em outras especialidades seria no mínimo insensato: o que está por aí não precisa ser copiado, tampouco incentivado. É preciso construir diferente, construir mais simples e quem sabe melhor.

Sem esta perspectiva, ainda que sustentada sobre o auto-engano, a fala do demônio criada por Nietzche transformar-se imediatamente numa grande maldição, em um grande e interminável castigo. 


\section{a bibliografia comentada}

\section{A reunião de uma bibliografia introdutória ${ }^{210}$}

A bibliografia de Conservação de Têxteis Históricos, hoje, é vastíssima, plurilíngüe, e é acrescida, a cada ano , por dezenas de novas contribuições, sejam elas publicadas ou não. Especialistas de museus, institutos de pesquisa e centros de formação, em todo o mundo, encontram-se ao menos uma vez ao ano - em seminários, conferências e/ou grupos de trabalho de diferentes características, níveis e objetivos -, para discutirem ou rediscutirem sua filosofia, métodos e técnicas de trabalho. Este ensaio, no entanto, limitar-se-á a apresentar comentários de parte dessa bibliografia, com limites e cortes bem precisos.

A reunião desses trabalhos teve início em 1991, quando se decidiu pela implantação dessa área nova no Museu Paulista e na Universidade de São Paulo. A escolha de títulos levou em consideração os seguintes fatores:

1. a especificidade das coleções de um museu histórico universitário;

\footnotetext{
${ }^{210}$ A aquisição e reprodução de sessenta por cento desta bibliografia foi possível graças ao financiamento da Samuel H. Kress Foundation, Nova York.
} 
2. a preferência por títulos em inglês, francês e italiano, excluindo-se, portanto, quase toda a bibliografia nas línguas alemã, escandinavas e leste-européias, quando não disponíveis idiomas citados, ${ }^{211}$

3. a indicação por parte de especialistas, daqueles textos considerados fundamentais às futuras discussões, quer teóricas quer metodológicas que se dariam, nas diferentes atividades da curadoria, com o início dos trabalhos em São Paulo. ${ }^{212}$

A bibliografia reunida, portanto, foi composta por trabalhos de naturezas diversas: livros e manuais de edição comercial, publicações institucionais, periódicos especializados, resumos e/ou textos de trabalhos apresentados em congressos e seminários, projetos acadêmicos de pesquisa, boletins informativos e estudos de caso.

Foram considerados, apenas, os trabalhos diretamente ligados à área de conservação de têxteis e alguns, de áreas correlatas como couro e metal, que necessariamente integram esse referencial bibliográfico. Os trabalhos que abordam a Conservação em geral, embora apareçam citados enquanto obra, tiveram discutidas, apenas, as partes relativas a têxteis. ${ }^{213}$

É preciso ainda citar, aqui, uma fonte importante de estudos e pesquisas não incluída em nossa bibliografia: os Diploma Reports, do The Textile Conservation Centre (TCC), Surrey, Inglaterra ${ }^{214}$. Esses trabalhos, desenvolvidos

\footnotetext{
${ }^{211}$ Sabe-se, entretanto, que a produção de livros e artigos de pesquisa em alemão, sueco, dinamarquês é húngaro é bastante grande e tem influenciado, por exemplo, a formação do referencial teórico-metodológico dos museus chilenos.

${ }^{212} \mathrm{O}$ trabalho de seleção de títulos que formaram parte substancial dessa bibliografia foi orientado, em 1992-1993, por Janey Cronyn - então Coordenadora'científica do The Textile Conservation Centre - Courtauld Institute of Arts - University of London - e Dinah Eastop, conservadora-orientadora da mesma instituição.

213 Não estão incluídos nesta bibliografia, os títulos dedicados exclusivamente à conservação de Tapeçarias, bem como os inúmeros periódicos que abordam a área têxtil direta ou indiretamente.

214 The Textile Conservation Centre, Apartment 22, Hampton Court Palace, East Molesey, Surrey, KT8 9AU, Inglaterra. (e. mail tccuk@compuserve.com)
} 
pelos profissionais formados pelo centro em seus vinte anos de existência, constituem, acreditamos, o que existe de mais sério e competente na área de conservação de têxteis. Infelizmente, o acesso a esses trabalhos só é possível na Biblioteca do TCC, em Hampton Court Palace, sendo sua reprodução vedada por tratar-se de trabalhos inéditos. Apenas um desses trabalhos, doado pela autora, encontra-se relacionado e disponível no Museu Paulista. ${ }^{215}$

A bibliografia comentada foi agrupada em tópicos e apenas comentada. Os comentários têm por objetivo tão somentea ilustrar, definir e apontar conteúdos. As eventuais críticas, cotejamentos e discussões dos textos - quando pertinentes -, foram incluídas nas discussões dos capítulos .

1. AS OBRAS ESSENCIAIS

FINCH, Karen; PUTNAM, Greta. The care \& preservation of textiles. London: B.T. Batsford, 1985. 144p. il.

Este livro é baseado em trabalho anterior, uma primeira versão, de mesmo título, publicada pelas a. em 1977. Trata-se de um guia, de planejamento cuidadoso e de fácil compreensão, destinado a todos aqueles que trabalham com têxteis históricos.

Karen Finch, profissional de formação dinamarquesa, foi responsável pela renovação dos trabalhos de conservação de têxteis no Victoria \& Albert Museum, Londres, e a fundadora, em 1975, do The Textile Conservation Centre, Surrey, Inglaterra, um dos principais centros de formação profissional e pesquisa na área de conservação de têxteis.

O trabalho fornece ao leitor informações de como e por que os têxteis deterioram e orienta o não- especialista a trabalhar a conservação preventiva dos objetos.

\footnotetext{
${ }^{215}$ Luciana da Silveira - The conservation of two pre-Hispanic Andean tunics: two contrasting approaches.
} 
São discutidos alguns exemplos de tratamentos realizados, visando auxiliar curadores e pesquisadores na avaliação de eventuais problemas na administração de acervos têxteis sob sua responsabilidade.

Os a. apresentam o The Textile Conservation Centre (TCC), seus objetivos e as definições de conservação, restauração, reparos, renovação, adotados pela escola desde sua fundação.

No final do trabalho há um pequeno glossário e encontram-se relacionados os materiais e equipamentos mais necessários aos trabalhos básicos de conservação.

\section{FLURY-LEMBERG, Mechtild. Textile conservation and research. Riggisberg: Abegg-Stiftung, 1988. 532p.il}

O livro é uma edição comemorativa dos vinte anos da Fundação Abegg, instituição voltada à coleta e pesquisa histórica de têxteis e detentora da maior coleção do Ocidente nesta tipologia de objetos

As atividades de conservação/restauração tiveram início em 1967 e estiveram, até 1994 , sob orientação da Prof. Flury-Lemberg. De formação alemã, foi responsável pela formação de dezenas de profissionais de vários países europeus.

$\mathrm{Na}$ introdução, a a. faz algumas considerações sobre a prática de preservação de têxteis por museus e instituições afins. Segundo a a., quando os tecidos começaram a ser recolhidos pelos museus, no século XIX, iniciaram-se as discussões sobre como estes deveriam ser preservados. Na Suécia, por exemplo, os têxteis começaram a ser coletados e conservados segundo os padrões domésticos de manutenção, e essa experiência, veio a determinar a metodologia de trabalho adotada por todos os museus nórdicos.

Na Alemanha, após a Segunda Guerra, a mudança de atitude em relação aos têxteis ocorreu por ocasião da chegada dos mantos do Papa Clemente II às mãos do historiador da arte Sigrid Muller-Christensen que, considerando imprópria a escolha de um alfaiate para restaurar o objeto, iniciou seus estudos em restauração e foi um dos pioneiros dos trabalhos especializados naquele país.

A a. discute, ainda na introdução, o conceito de autenticidade e explicita a metodologia de trabalho adotada pela Fundação. Para ela, o conservador deve 
ter em mente que está trabalhando com uma obra-de-arte, que precisa ser observada como tal, não se justificando, portanto, sua preservação com sujidades, ou partes em desprendimento

$\mathrm{Na}$ primeira parte do livro, a autora discute a importância da documentação, apresenta os métodos de limpeza adotados pela instituição e cita alguns tratamentos mal conduzidos com a utilização de adesivos plásticos. Os sistemas de armazenagem e exposição, considerados os melhores do mundo, são ilustrados em detalhe, fornecendo ao leitor uma idéia geral de como sistemas perfeitos devem ou podem ser.

Na segunda parte do livro, são apresentadas ilustrações, em cores, de aproximadamente uma centena de tratamentos realizados. A terceira parte, descreve cada um dos tratamentos, apresentando a ficha catalográfica dos tecidos anteriormente citados. A quarta e última parte apresenta uma longa bibliografia em alemão.

\section{LA CONSERVATION DES TEXTILES ANCIENS. Journées d'Études de la SFIIC. Angers, outubro de 1994.293p.il.}

A publicação francesa, com texto introdutório de L. Masschelein-Kleiner, reúne vinte quatro trabalhos divididos em: Abordagem histórica e científica; Metodologia/museologia; e Estudos de caso. Um pequeno glossário bilingüe (francês/inglês) poder ser encontrado ao final da edição. O livro é uma das poucas publicações sobre conservação de têxteis disponíveis em francês.

\section{LANDI, Sheila. The textile conservator's manual. 2.ed. London: Butterworth-Heinemann, 1992. 340p. il.}

Este livro integra a Butterworth-Heinemann Series in Conservation and Museology e foi publicado pela primeira vez em 1985, ano em que a a. assumiu a coordenação do Departamento de Conservação de Têxteis do Victoria \& Albert Museum, Londres. Como a coleção emprega um padrão único nos seus volumes, os textos apresentam, necessariamente, conteúdos balanceados entre informação teórica e prática. 
Esta segunda edição foi acrescida por vários estudos bastante mais aprofundados, assinados por outros profissionais e cientistas da área. O livro é dividido em duas partes: o manual, propriamente dito e os estudos de caso.

O manual se inicia discutindo a profissão do conservador, sua formação, sua atitude e limites de atuação. Seguem-se estudos detalhados sobre as principais fibras, sobre sua construção, estrutura, tingimento, relação com corantes e pigmentos, para, só então, discutirem-se as etapas do trabalho de abordagem do objeto têxtil.

A a. discute as várias fases do planejamento do exame a ser realizado : o que observar e quais perguntas formular durante a abordagem do têxtil histórico. Sheila Landi propõe nove categorias de análise e apresenta um roteiro para o levantamento dos principais problemas. A seguir, a a. discute a documentação e as principais questões envolvidas: preparação física do objeto e a importância dos testes. Define termos como flamabilidade, ponto de ignição, toxicidade, polaridade, etc, que introduzem, teoricamente, o estudo da profissional holandesa, J.Hofenk de Graaf, sobre detergência e utilização de solventes na conservação de têxteis.

Das teorias sobre detergência passa-se a discutir o tingimento: o comportamento das principais fibras em relação aos tipos de corantes exaustivamente testados e disponíveis, hoje, no mercado.

A seguir a a. aborda as questões envolvidas com a exposição de objetos. Discutem-se não apenas as questões específicas das diferentes tipologias, como, também, as várias possibilidades de abordagem e interpretação, por parte do conservador, na preparação de um objeto que vai ser exposto. Segundo a a., um mesmo objeto será exposto de forma diferente em um museu de história social, em um museu de moda, e em um museu de arte.

Esta primeira parte do livro apresenta, ainda, a descrição e imagens para um laboratório básico, e um apêndice sobre materiais e diferentes teceduras.

A segunda parte do livro apresenta exclusivamente estudos de caso. Em cada um, discute-se a abordagem, o método e a opção escolhida em cada situação. Os tratamentos desenvolvidos são descritos e discutidos do ponto de vista de sua eficácia. 
LEENE, Jentina, org. Textile conservation. London: Butterworths, The International Institute for Conservation of Historic and Artistic Works (IIC), 1972. 275p. il.

A publicação, de iniciativa do IIC, foi organizada por Jentina Leene no final da década de 1960. Este trabalho pioneiro de sistematização dos conhecimentos da área, apresenta narrativas bastante diferenciadas, já que cada capítulo foi coordenado por um profissional com experiência específica em determinada tipologia de objeto. Assim, cada um dos capítulos é apresentado, abaixo, com a indicação do nome e instituição de seu autor.

O primeiro capítulo, introdutório, e o segundo, Textiles, são de responsabilidade da coordenadora. Nele, a a. aponta a expressão têxtil como definidora não só de uma tecedura, mas também, daqueles objetos que tenham sido fabricados à partir de uma tecedura. Ele se aplicaria, igualmente, assim, às estruturas construídas a partir de fios, como as malhas, o bordado e mesmo, a materiais como o feltro e os não-tecidos, já que, segundo a a., o tratamento mecânico que originou sua produção lhes conferiu coerência estrutural. A a. exclui de sua definição, no entanto, os objetos de cestaria que não se apresentem na forma de indumentária.

Natural Dyestuffs, é de autoria de Johanna M. Diehl, do Atelier de Restauração de Tecidos Antigos em Haarlem, Holanda.Traz um pequeno histórico da utilização de pigmentos e corantes naturais em diferentes culturas e aborda, brevemente, os problemas que eles podem apresentar em situação de degradação e/ou durante um processo conservativo de estabilização.

Principles of Fragile Textile Cleaning, foi trabalhado por James W. Rice, pesquisador do The Textile Museum, Washington. O cientista preocupa-se em responder às principais questões que, segundo ele, todos os conservadores se colocam ao abordar um têxtil fragilizado, sejam elas de natureza teórica, metodológica ou técnica.

Bleaching, também de autoria da coordenadora, discute a necessidade, às vezes imperativa, de realizar-se o branqueamento em unidades de acervo como rendas e roupas intímas, admitindo, entretanto, a subjetividade desse raciocínio, na medida em que se sabe ser praticamente impossível, a determinação do tom ou nuance de branco que um objeto possuiu originalmente. Além disso, lembra a 
a., não se pode esquecer que agentes azuladores como o indigo e a anilina foram acrescidos aos têxteis durante os processos de branqueamento e que esses elementos não podem ser recuperados.

Textile Pests and Their Control, foi desenvolvido por H.J. Hueck, Chefe do Departamento de Biologia, Central Laboratory TNO, Delft. O a. discute a biodeterioração dos têxteis, examinando cada um de seus possíveis agentes e então sugere métodos químicos e físicos para seu controle e monitoramento.

Textiles in the Museum Environment, ensaio apresentado por Garry Thomson, consultor científico da National Gallery, Londres, discute os principais fatores a serem considerados na relação têxteis-ambiente.

Storage and Display, de autoria de Anne Breck, da The Gallery of English Costume, Manchester e de Jentina Leene, discute os tópicos abordados anteriormente, do ponto de vista da armazenagem e da exposição de longa permanência. São discutidas, ainda, algumas propostas para acondicionamento.

The Equipment of a Textile Conservation Workroom, é de autoria de Sheila Landi, do Departamento de Conservação de Têxteis do Victoria \& Albert Museum, Londres, que apresenta, brevemente, os equipamentos e ferramentas básicos aos trabalhos de conservação.

Restoration and Conservation, foi desenvolvido por Johan Lodewijks, Diretor do Central Research Laboratory for Objects of Art and Science, Amsterdam, e de Jentina Leene. São apresentados, de forma sucinta, alguns métodos de intervenção. São ilustradas as principais técnicas reparativas com pontos de costura e apresentadas algumas receitas para utilização de adesivos sintéticos.

Tapestries, é de responsabilidade de Johanna M. Diehl e F. Visser, do Workshop for Restoration of Ancient Textiles, Haarlem que apresenta, brevemente, as principais características das tapeçarias e os métodos utilizados em sua conservação e restauração.

Carpets, foi escrito por Dora Heinz, do Austrian Museum of Applied Art, Viena. Nele a a. discute os principais problemas de conservação apresentados por essa tipologia de objetos e sugere métodos de limpeza e restauração a partir de sua experiência com a coleção austríaca. 
Flags and Banners, trabalhado por Johan Lodewijks, diretor do Central Research Laboratory for Objects of Art and Science, Amsterdã, discute os métodos utilizados na conservação de bandeiras e estandartes. $\mathrm{O}$ a.classifica estruturalmente esses objetos, para então discutir os processos de higienização e intervenção em cada uma das categorias estabelecidas.

White Linen Damasks, preparado por C.A. Burgers, do Departament of Sculpture and Applied Art, Rijksmuseum, Amsterdã, descreve, brevemente, um processo para limpeza,- por pressão mecânica em meio aquoso, - desta tipologia de têxtil.

Historic Costumes, foi trabalhado por Gudrun Ekstrand, do The Kungliga Livrustkammaren (The Royal Armoury), Stockholm. Os principais problemas que afetam os trajes históricos são abordados brevemente pelo a., que apresenta, ali, alguns estudos de caso desenvolvidos pela instituição sueca .

Uniforms, foi escrito por P.M. Mader, do Departmant of Conservation of Military Textiles, Swiss National Museum, Zurich, e por J.G. Kerkhoven, conservador do The Netherlands Army Museum, Leiden. Esta tipologia de trajes históricos é discutida em capítulo à parte, devido a especificidade de problemas que costuma apresentar. Uma grande quantidade de acessórios aplicados e a consequente diversidade de materiais encontrados, geralmente requerem procedimentos especiais de conservação. Os a. sugerem alguns procedimentos técnicos de limpeza e discutem a importância decisiva de um suporte correto para esses trajes, seja para armazenagem, seja para exposição.

Lace, é de autoria da profissional portuguesa, Maria José Taxinha, do Instituto José de Figueiredo, Lisboa, que discorre sobre os principais cuidados necessários à boa conservação de rendas, em geral.

Beadwork, foi escrito por Karen Finch, do Victoria \& Albert Museum, Londres. A a. discute os problemas mais comuns apresentados pelas contas, sejam elas produzidas com materiais proteicos, vegetais ou sintéticos.

Gloves, também de autoria de Karen Finch, discute a especificidade desses têxteis e descreve alguns procedimentos de conservação adotados em unidades do acervo do Victoria \& Albert Museum.

O tema Ethnographical Textile Collections, foi desenvolvido por A.C. van der Leeden, do Indonesian Department, National Museum of Etnology, 
Leiden. $\mathrm{O}$ a. discute, em seu ensaio, as influências de ordem cultural que afetam os métodos e técnicas utilizados em conservação. Para ele, as noções ocidentais de cultura que permeiam e são referência à conservação e restauração de têxteis não podem ser aplicadas, simplesmente, a objetos oriundos de culturas nãoocidentais.

Ethnographical Featherwork, de autoria de Harold J. Gowers, Department of Etnography, British Museum, Londres, discute a especificidade do trabalho de conservação de objetos com plumária, salientando que alguns cuidados básicos podem, certamente, diminuir a necessidade futura de intervenção. São descritos, também, alguns estudos de caso trabalhados naquele museu.

Some New Techniques for Archaeological Textiles, foi preparado por Hanna Jedrezejewska, Research Laboratory, Department of Antiquities, National Museum, Warsaw. A a. apresenta algumas técnicas de conservação para têxteis arqueológicos que, segundo ela, levam em consideração a especificidade dos objetos. Tais técnicas devem, obrigatóriamente, considerar esses aspectos: reversibilidade máxima; pequena utilização de produtos químicos; não alteração das propriedades físicas do objeto ; garantia de acesso ao verso do têxtil e não agressão a autenticidade da peça.

O último tema discutido, Leather Objects, foi preparado por John W. Waterer, Museum of Leathercraft, London. $\mathrm{O}$ a. fornece elementos para que o não-especialista saiba como diferenciar um couro de outro material semelhante. São discutidos , brevemente, sua composição, natureza e os principais processos utilizados em seu beneficiamento. Também são fornecidas algumas orientações básicas à sua conservação.

\section{A TEORIA}

BROOKS, Mary; CLARK, Caroline; EASTOP, Dinah; PETSCHEK, Carla. restoration and conservation - issues for conservators: a textile conservation perspective. In: RESTORATION. IS IT ACCEPTABLE ? BRITISH MUSEUM CONFERENCE, London, British Museum, 1994, p. 103-114. (British Museum Occasional Papers, 99). ${ }^{216}$

216 Publicado em português como : Conservação e Restauração: algumas questões aos conservadores. A perspectiva da conservação de têxteis. IN: ANAIS DO MUSEU 
O texto discute as idéias e diferentes conotações que os conceitos de conservação e restauração trazem em diferentes idiomas e culturas. São discutidas as possíveis diferenças de abordagem, procedimentos e objetivos que as duas atividades apresentam, hoje.

CONFERENCE AT THE BRITISH MUSEUM: RESTORATION, IS IT ACCEPTABLE? London, 1994. /Resenha de RICHMOND, Alison. $V \& A$ Conservation Journal, n.15, p.10-11, Apr. 1995. (London, Victoria \& Albert Museum).

A resenha apresenta as principais conclusões dos especialistas de diversos países e instituições que participaram dessa Conferência.

O papel da Conservação institucional, hoje, em suas diversas modalidades, sua ética, prática e métodos, encontra-se discutida no texto. Aspectos como modismo. gosto, segurança, função e motivação são alguns elementos que, segundo o a., foram apontados como determinantes do referencial teórico e prático do profissional Conservador.

JEDRZEJEWSKA, Hanna. Problems of ethics in the conservation of textiles. IN: CONSERVAZIONE E RESTAURO DEI TESSILI: CONFERENCIA INTERNAZIONALE. Como, 1980. p. 99-103

A profissional polonesa preocupa-se, nesse trabalho, em discutir as principais questões éticas específicas da atividade de conservação de objetos têxteis.

Segundo a a., todo conservador, ao abordar um objeto têxtil, deve considerar três espécies distintas de características: a matéria-prima e suas propriedades originais; o design; e a mão-do-artífice, ou seja: o reflexo, no objeto, das características individuais de uma determinada técnica de produção.

A a. introduz na discussão, o conceito de documento, que, afirma, está necessariamente ligado à questão da autenticidade. Segundo afirma, um objeto

PAULISTA. São Paulo. N. Ser p. 235-250 jan/dez. 1994. Tradução Teresa Cristina Toledo de Paula 
só pode ser considerado um documento enquanto mantiver sua autenticidade. $\mathrm{E}$ nos objetos antigos, a autenticidade implica na existência de características originais, primárias, quer de seus materiais, quer de suas características humanas. Assim, coloca Jedrzejewska, é preciso que o profissional dimensione e assuma estar interferindo diretamente na essência do objeto, e fazendo com que características importantes possam vir a perder-se durante os trabalhos de conservação.

Para a a., cabe ao profissional lembrar-se, sempre, que a meta principal da conservação é proteger a substância de cada objeto de sua contínua deterioração, além de melhorá-lo do ponto de vista estético. E que quando a combinação destas operações torna-se inviável e muitas de suas características correm o risco de ser sacrificadas em detrimento de outras, o profissional precisa ter claro quais são os parâmetros éticos, técnicos e históricos que fundamentam suas decisões.

KAHLENBERG, Mary Hunt. Collecting considerations. In: Textile Conservation Symposium. Los Angeles: Los Angeles County Museum of Art, 1986. p. 54-57

Este artigo narra a trajetória de um Pua, tecido cerimonial produzido em Borneo, desde o ritual da escolha dos fios de algodão para tecê-lo, até sua doação, décadas depois, ao museu americano.

A a. discute e sugere que conservadores e curadores investiguem em profundidade e conheçam melhor o histórico dos objetos com os quais lidam, antes de abordá-los e submetê-los a determinado tratamento ou modo expositivo. Mesmo concordando que todo objeto musealizado, é, necessariamente, re-semantizado, a a. propõe que os profissionais tenham evidenciados os limites da interpretação em seus trabalhos, sejam eles de conservação, sejam de pesquisa.

KAJITANI, Nobuko. Cuidado de los tejidos em el Museo. Apoyo, v.4, n.1, 1993. Traduzido do original em inglês. Preservation of Paper and Textiles of Historic and Artistic Value. Advances in Chemistry. Series 164, p.161-180.(American Chemical Society: Washington, DC, 1977, Copyright 1977 American Chemical Society). 
O texto traz uma série de direções teóricas e técnicas àqueles profissionais de museus que lidam com objetos têxteis, direta ou indiretamente.

A a., responsável pela redefinição dos trabalhos com têxteis nesse museu e indiretamente, nos Estados Unidos, define a preservação como atividade contraposta à conservação. Preservação compreenderia toda a atividade permitida e não permitida que contribua para garantir a vida dos objetos, estejam estes em exposição, armazenados, em manipulação, em estudo ou sob tratamento. Já a Conservação, referir-se-ia ao tratamento radical, realizado em um laboratório, com o objetivo de devolver ao objeto uma aparência semelhante à original, e estabilizar sua condição físico-química através do acréscimo de novos materiais.

O texto apresenta recomendações de ordem genérica sobre o manuseio de têxteis, salientando os danos que atividades mal planejadas podem causarlhes.

\section{ORLOFSKY, Patsy; TRUPIN, Deborah Lee. The role of connoisseurship} in determining the textile conservator's treatment options. Journal of the American Institute for Conservation v.32, n.2, p. 109-118, 1993.

Os a. sugerem, neste artigo, três ordens de fatores a serem consideradas antes que o conservador determine a natureza de sua intervenção sobre um objeto. O primeiro fator, de natureza classificatória, seria o de definir funcionalmente o tipo de têxtil a ser abordado: se indumentária, se documento, etc. O segundo fator determinante, seria a formação do conservador (background) responsável pelo projeto e, o terceiro, a combinação dos dois primeiros na execução do trabalho de conservação.

Para os a., um mesmo profissional terá sua atitude constantemente questionada, aprimorada e, com certeza, seu trabalho, em determinada coleção de objetos, refletirá todas essas mudanças de atitude.

\section{PUBLICAÇÕES RESULTANTES DE CONGRESSOS E/OU ENCONTROS ESPECÍFICOS.}


CONSERVATION OF FURNISHING TEXTILES. Glasgow, 1990. Postprints. Glasgow, The Scottish Society for Conservation \& Restoration (SSCR), 1990. 110p. il.

A publicação reúne alguns trabalhos apresentados na Conferência de mesmo nome, realizada na The Burrell Collection, Glasgow, em março de 1990, sob coordenação da SSCR e do United Kingdom Institute for Conservation (UKIC). Todos os ensaios são estudos de caso desenvolvidos por conservadores de instituições inglesas e americanas.

\section{CONSERVAZIONE E RESTAURO DEI TESSILI. Convegno Internazionale. Como, 1980, Centro Italiano per lo Studio della Storia del Tessuto - Sezione Lombardia, 285p. il.}

A publicação reúne 47 trabalhos de conservadores e cientistas de várias nacionalidades que foram agrupados em cinco sub-grupos: 1 . Conservazione dei tessili: il controllo delle condizioni ambientali; 2. conservazione dei tessili: la pulitura; 3. conservazione dei tessili: il restauro; 4. Profilo di un centro per la conservazione e il restauro dei tessili; 5. esperienze di restauro.

\section{FABRIC OF AN EXHIBITION: AN INTERDISCIPLINARY} APPROACH, Ottawa, 1997. Preprints. Ottawa, Textile Symposium 97, Canadian Conservation Institute, 1997. 206p. il.

A publicação reúne os trabalhos apresentados durante a primeira conferência norte-americana sobre conservação de têxteis. Os textos em inglês (com resumo em francês) foram agrupados da seguinte forma: Perspectivas em relação à exposição de têxteis; Mostras em casas históricas; Considerações a longo prazo; A exposição e seu meio ambiente; Exposições itinerantes; Suportes e formas de apresentação; e Expansão de 'tarefas'. 
PAPER AND TEXTILES: THE COMMON GROUND, Glasgow, 1991. Preprints. Glasgow, The Scottish Society for Conservation \& Restoration (SSCR), 1991. 136p. il.

A publicação reúne trabalhos apresentados no encontro de mesmo nome realizado pela SSCR na Burrell Collection, Glasgow, em setembro de 1991. Durante o encontro foram apresentados trabalhos de pesquisa sobre questões técnicas e práticas relacionadas à conservação de materiais celulósicos. São discutidas as diferenças e similitudes químicas e o uso de equipamentos e materiais.

Destacam-se, aqui, dois trabalhos: Cellulose in Paper and Textiles, de Anthony Smith, aponta o que para ele seriam as quatro ordens de diferenças fundamentais entre os dois produtos: a) quanto à estrutura; b) quanto ao estado físico das fibras; c) quanto à essência química das fibras; d) quanto ao grau de degradação da celulose. A pesquisa demonstra, ainda, como as diferentes fibras reagem quando imersas em água e como as fibras de papel, durante seu processo de manufatura, sofrem mais ataques físicos e químicos do que as têxteis.

Wet cleaning of paper and textiles: similarities and differences, de Vincent Daniels e Yvonne Shashoua, discute os métodos de conservação dos dois materiais, modos de abordagem e tratamentos mais utilizados. Os a., dentre outras, discutem a hipótese de que os tratamentos de conservação tenham sido influenciados pelas atividades comerciais e abordagens domésticas dos materiais envolvidos.

A conservação de têxteis seria, então, herdeira do trabalho de manutenção doméstica dos têxteis, tendo desenvolvido métodos de trabalho que envolvem e privilegiam a limpeza em meio aquoso, o detergente, a agulha e a linha como instrumentos. Já a conservação de papel, teria, assim, surgido dentre as atividades de encadernação, impressão e fabricação de papel. Daí, então, sua preferência pelo uso de adesivos e clareamentos.

Os demais trabalhos apresentam estudos de caso de objetos compostos, como mostruários de tecelagens e obras de arte. 
PASCOE, M.W. Science and ethics in textile conservation In: CONSERVAZIONE E RESTAURO DEI TESSILI: CONVEGNO INTERNAZIONALE. Como, 1980, p. 104-106. (Centro Italiano per lo Studio della Storia del Tessuto - Sezione Lombardia).

O profissional do British Museum procura, neste texto, apontar o que segundo ele deva ser a questão principal com a qual se deparam todos os conservadores de têxteis: o que deve ser conservado em um objeto têxtil, e por que deve ser preservado?

$\mathrm{O}$ a. aponta sua dificuldade em responder estas questões quando se abordam objetos tão complexos quanto os têxteis: fios, estruturas, manchas, pigmentos que se alteram com o tempo e provocam reações químicas em determinadas partes ou áreas, remendos, etc.

Ao elencar uma série de tratamentos e opções de trabalho executados no British Museum, Londres, o a. enfatiza a necessidade do conservador trabalhar em conjunto com químicos têxteis e dispor de um laboratório bem equipado.

\section{SAVING THE TWENTIETH CENTURY: THE CONSERVATION OF MODERN MATERIALS. Ottawa, setembro de 1991. Proceedings of a Conference. Ottawa, Canadian Conservation Institute, 440p. il.}

O livro apresenta artigos apresentados no encontro realizado pelo Canadian Conservation Institute em setembro de 1991. Os trabalhos foram divididos em sete grupos: 1. Materiais Modernos nas coleções; 2. Projetos e Políticas de Conservação; 3. História da Tecnologia; 4. Processos de degradação; 5. Estudos de caso: problemas específicos com materiais. 6. Elaboração e desenvolvimento de métodos de conservação; 7. Métodos de análise e identificação.

Quatro trabalhos são específicos da área têxtil: Ardil: The Disappearing Fibre?, de Mary M. Brooks; Degradation of Polyurethanes in 20th-Century 
Museum Textiles, de Nancy Kerr e Jane Batcheller; Treatment of 20thCentury Rubberized Multimedia Costume: Conservation of a Mary Quant Rain Coat (ca.1967), de Clare Stoughton-Harris e Spacesuits: NASA's Dream - Conservator's Nightmare, de Mary T. Baker and Ed McManus.

\section{SILK - DIFFERENT ASPECTS. Stockholm, set. 1977. Svenska} Föreningen för textilkonservering, 1977, 70p. il.

A publicação traz vinte dois estudos de caso apresentados no encontro homônimo, todos eles discutindo problemas e soluções encontradas na conservação de objetos produzidos parcial ou totalmente em seda. A extensão e abordagem dos textos, todos em inglês, não é uniforme.

\section{SYMPOSIUM RIJKSMUSEUM: CONSERVATION OF FLAGS.} Amsterdam, nov. 1977 Recommendations adopted at the working session. Amsterdam, Rijksmuseum, 1977. 6p.

O texto apresenta as recomendações de ordem geral e técnica para a abordagem de bandeiras, deliberadas pelos participantes daquele Simpósio. São indicados padrões para descrição dos diversos tipos de bandeiras e estandartes e sugeridas algumas recomendações gerais para a conservação dessa tipologia.

TATE, J.O; TENNENT, N.H.; TOWSEND, J.H., eds. Resins in conservation: the proceedings of the symposium. Edinburgh, Scottish Society for Conservation and Restoration (SSCR), 1988. 122p. il.

A publicação reúne trabalhos apresentados no seminário de mesmo nome, realizado na Universidade de Edimburgo ,em maio de 1982. Destaque-se, aqui, a pesquisa de Dilys Blum, Conservadora do Museu de Londres, An evaluation of some uses of synthetic resins in textile conservation, 8p.il.

A a. analisa o uso que a Conservação de Têxteis tem feito das resinas sintéticas nos últimos trinta anos. Apesar das controvérsias que o uso de adesivos 
têm gerado, afirma a a., poucos estudos de avaliação foram realizados. Seu trabalho discute e reavalia uma série de tratamentos realizados no Museu de Londres, no passado, e o comportamento desenvolvido pelos objetos através do tempo.

Segundo a a. é imprescindível o acompanhamento e a reavaliação das resinas aplicadas a médio e longo prazos. Problemas como maior atração de partículas , craquelamento devido a menor flexibilidade das fibras na relação Umidade Relativa/Temperatura, surgimento de manchas e alterações cromáticas, foram alguns dos problemas detectados.

WILLIAMS, Marc A., ed. Upholstery conservation: preprints. s.l. Colonial Williamsburg American Conservation Consortium, 1990. (Symposium)

A publicação apresenta trinta e um trabalhos apresentados no Simpósio, subdivididos em seis grupos: Upholstery Conservation Overview; Analysis and Documentation; Upholstery Materials; Upholstery Styles and Techniques; General Conservation Treatment; Treatment Case Histories.

\author{
4. CONSERVAÇÃO/RESTAURAÇÃO GERAL, COM CAPÍTULOS \\ DEDICADOS À ÁREA TÊXTIL.
}

\title{
ASSOCIATION DES CONSERVATEURS-RESTAURATERS EN TEXTILES (A.C.R.E.T.). Textiles: mesures de conservation préventive, grandeurs et mesures. In: LA CONSERVATION PRÉVENTIVE: Colloque sur la conservation/restauration des biens culturels, Paris, oct. 1992. Paris, Association des restaurateurs d'Art et d'Archéologie de formation universitaire (A.R.A.A.F.U.), oct. 1992, p. 241-244 \\ $\mathrm{O}$ artigo, de autoria coletiva, apresenta as principais etapas a serem seguidas em um trabalho de conservação de coleções têxteis, quando abordadas como um todo.
}


A metodologia descrita foi elaborada pelos a., a partir de três projetos desenvolvidos em coleções têxteis francesas : reacondicionamento das coleções do Musée de la Mode et du Costume ; do Conservatoire National des Arts et Métiers; e da Maison Lanvin.

Os a. sugerem que projetos envolvendo grandes coleções sejam estruturados e desenvolvidos em cinco etapas. A primeira, consistiria em arrolar e compreender os objetivos e a natureza dos fatores envolvidos no desenvolvimento do projeto: uma situação de emergência, um projeto de melhoria de infra-estrutura, um projeto de cunho político, etc.

A segunda, envolveria o contato com diferentes especialistas. Somente na terceira etapa, então, é que os conservadores-restauradores diagnosticariam a situação, examinando o local, a coleção e os meios disponíveis para a execução do trabalho.

A fase quatro, compreenderia a documentação do estado de conservação de cada objeto: uma descrição, registro fotográfico e confecção de nova embalagem permanente.

A quinta e última fase, seria a própria instalação física dos objetos já conservados, em situação de reserva ou exposição.

Alguns pressupostos éticos são arrolados brevemente pelos a. e, ao final do artigo, é indicada uma bibliografia sumária, datada de 1974 a 1990.

\section{BACHMANN, Konstanze, ed. Conservation Concerns: a guide for collectors and curators. New York: Cooper-Hewitt National Museum of Design/ Smithsonian Institution, 1992. 149p. il.}

Conjunto de ensaios produzidos por especialistas de diferentes áreas da Conservação sob coordenação do Cooper-Hewitt National Museum of Design, de Nova York. Dirigido a curadores e demais profissionais envolvidos com coleções museológicas, o trabalho procura tornar acessíveis os conhecimentos e procedimentos básicos de conservação.

O livro apresenta cinco ensaios sobre Conservação de Têxteis: Storage of Historic Fabrics and Costumes; Textile Conservation; Storage Containers for Textile Collections; Upholstery Conservation. 


\section{INSTITUT CANADIEN DE CONSERVATION. Notes de L'ICC. Ottawa: Canadian Conservation Institute, s.d. 34p. il.}

A publicação disponível em inglês e francês (antes oferecida gratuitamente a instituições que abrigam coleções em todo o mundo e, hoje, vendida) apresenta, sob a forma de fichas, recomendações gerais a preservação de objetos históricos.

Aos têxteis, dedicam-se treze fichas, que abordam desde questões sobre os efeitos da luz e do ambiente sobre os objetos, a outras bastante específicas como, por exemplo, a que traz recomendações para a lavagem de têxteis, a seco, por empresas particulares.

KÜHN, Hermann. Conservation and restoration of works of art and antiquities. London: Butterworths, 1986. v. 1, 34p. il.

A obra, em dois volumes, integra a Butterworth-Heinemann Series in Conservation and Museology. O primeiro volume, apresenta um texto denso sobre Têxteis e pequenas inserções sobre Corantes e Pigmentos e Fibras Têxteis. Têxtil ,para o a., é qualquer produto feito de fios. Assim, encontram-se descritas as formas básicas de teceduras, tapeçarias, bordados e rendas, sendo apresentadas recomendações preventivas, de ordem genérica, no tocante aos cuidados com luz e poluição.

A seguir, são indicados, brevemente, os procedimentos adotados em tratamentos de limpeza aquosa e, descritas, as principais técnicas utilizadas para reparos.

O texto sobre Corantes e Pigmentos apresenta, de forma sucinta, as principais características desses materiais e seus processos de utilização. O texto sobre Fibras Têxteis, discute cada uma das fibras quanto à micro-estrutura e composição química.

PLENDERLEITH, H.J. The conservation of antiquities and works of art: treatment, repair and restoration. London: Oxford University Press, 1956. 373p. il. 
Este trabalho pioneiro da área de conservação como um todo, foi escrito para orientar colecionadores, curadores e arqueólogos, conforme afirma o a.

No capítulo dedicado aos têxteis, o então Cientista-Chefe do Laboratório de Conservação do British Museum, apresenta, em detalhe, os procedimentos para a realização de lavagens aquosas e a seco, indica os principais solventes utilizados na "remoção" de manchas, e introduz a discussão sobre a importância do que hoje entendemos por conservação preventiva.

SAAVEDRA MÉNDEZ, Jorge. Conservación y restauración de antigüedades y objetos de arte. Buenos Aires: Librería Hachette, 1945. 365p.

O texto, dirigido a colecionadores, apresenta dois capítulos de recomendações para o cuidado dos têxteis. Um, Las Sedas y los Tejidos, traz alguns procedimentos de lavagem a seco e receitas para remoção de manchas. Outro, Tapices y Alfombras, indica já, em 1945, alguns sistemas de armazenagem em cilindro, discutindo suas principais vantagens.

Ambos discutem os efeitos da luz, da umidade e dos insetos na degradação desses objetos.

SHELLEY, Marjorie. The care and handling of art objects: practices in the Metropolitan Museum of Art. New York: Bradford, 1987.

O manual da instituição americana, apresenta dois capítulos dedicados à conservação dos têxteis: Textiles e Costumes.

Ambos apresentam recomendações conservativas no tocante ao ambiente, iluminação, armazenagem, manuseio, uso de biocidas e transporte desses objetos.

THOMPSON, John M.A. Manual of curatorship: a guide to museum practice. Oxford: Butterworth-Heinemann, 1992.

O manual, editado pela primeira vez em 1984, destina-se a todo profissional envolvido com a direção e administração de museus. Sua terceira 
parte, Conservation, discute as características gerais das várias tipologias de objeto.

O capítulo Conservation and storage: textiles, inicia definindo têxtil, como uma estrutura tecida e produzida através do entrelaçamento de dois grupos de fios, afirmando, todavia, que, no contexto do museu, o termo é ampliado e utilizado para designar três categorias de objetos que contenham matéria têxtil: dos planos, dos tridimensionais e dos compostos.

Ricamente ilustrado, apresenta vários exemplos de objetos antes e após os trabalhos de conservação, centrando sua discussão, entretanto, nas várias opções de suporte e estruturas para armazenagem permanente. Ao final, o texto traz bibliografia específica, organizada por assunto: análise técnica, introdução à conservação, ambiente do museu, manuseio (transporte, armazenagem e exposição), laboratório, segurança, ética e periódicos afins.

5. RECOMENDAÇÕES GERAIS SOBRE CONSERVAÇÃO DE TÊXTEIS.

\section{LISTER, Alison. GUIDELINES FOR THE CONSERVATION OF} TEXTILES. London, Ancient Monuments laboratory, Conservation and Technology Branch, 1996. 19p. il. (Scientific and Technical Publications Guideline N. 5)

O texto dirigido a não especialistas apresenta todas as questões envolvidas na conservação de têxteis: da classificação das técnicas e objetos à descrição dos princípios básicos da prática profissional. Apresenta glossário e sugere uma bibliografia básica.

MAILAND, Harold F. Considerations for the care of textiles and costumes. Indianapolis, Indianapolis Museum of Art, 1980. 25p. il.

Este trabalho, desenvolvido pelo a. durante quatro anos de estágios em diversos laboratórios de conservação têxtil dos Estados Unidos, é um guia para 
os não-especialistas.Controle ambiental, iluminação, fungos e insetos, são alguns dos tópicos desenvolvidos de forma sucinta. Os tópicos sobre armazenagem e preparo de exposiçõos, fornecem informações sobre os cuidados básicos a serem tomados por aqueles que mantêm contato direto com acervos e coleções têxteis.

PAUlA, Teresa Cristina Toledo de. Iniciação à conservação $e$ restauração de têxteis históricos. São Paulo, Museu Paulista/USP, abr. 1994, 22p. il. (Apostila desenvolvida para o curso de difusão cultural, homônimo).

A apostila apresenta, em sua primeira parte, quatro séries de recomendações técnicas para profissionais que trabalham diretamente com objetos têxteis históricos: para manuseio seguro; para guarda em reserva; para exposição; para limpeza mecânica.

A segunda parte traz, traduzido pela a., o texto Questões éticas na conservação de têxteis, de Hanna Jedrzejewska (vide nesta bibliografia).

PAULA, Teresa Cristina Toledo de. A conservação do patrimônio têxtil. Revista da Biblioteca Mario de Andrade. São Paulo, v.52, jan./dez.1994, p.167-175.

$\mathrm{O}$ artigo discute o caráter de novidade atribuído à Conservação de Têxteis no Brasil e apresenta algumas questões teóricas específicas sobre ética na conservação de têxteis. São mencionados alguns dos problemas mais frequentes enfrentados pelos profissionais da área, a partir da experiência de trabalho da a. no Museu Paulista da Universidade de São Paulo.

A a., nesse contexto, utiliza-se da expressão patrimônio têxtil para definir todos os tecidos - planos ou não - produzidos em determinado momento histórico e toda a enorme diversidade de objetos produzidos a partir desses tecidos.

O artigo apresenta ,ainda, três roteiros com instruções de procedimentos seguros, destinados aos profissionais não-especialistas que trabalham diretamente com objetos têxteis: recomendações para o manuseio 
seguro de objetos têxteis; recomendações para a guarda de têxteis em reserva e recomendações para a exposição de têxteis.

PAULA, Teresa Cristina Toledo de. Conservação de Têxteis. Começando uma nova atividade: a experiência do Museu Paulista da USP IN: CONSERVAÇÃO E RESTAURO I. Recomendações e projetos em andamento na Universidade de São Paulo.SP, Pró-Reitoria de Cultura e Extensão Universitária - Comissão de Patrimônio Cultural, 1996,p.83-89.

A texto traz um pequeno balanço do projeto de implantação deste setor na Universidade de São Paulo ,sugere uma bibliografia básica e apresenta, também, algumas recomendações para a conservação de acervos têxteis.

RICE, James W. Conservação de têxteis. Rio de Janeiro, CETIQT/SENAI, 1987. 325p. (Série de artigos do autor, traduzidos para o português e reunidos em apostila para o Curso Introdução à conservação e restauração de têxteis antigos e/ou históricos).

Os 13 artigos do cientista americano, produzidos na década de 1960, abordam as estruturas físicas e químicas das fibras têxteis, os problemas da relação conservação/ambiente e as vantagens e desvantagens encontradas no processo de lavagem por meio aquoso.

6. TRABALHOS PRODUZIDOS NO MUSEU PAULISTA DA USP.

COSTA, Luciana Ciglioni Martins. Faixas têxteis: bandas, talins e cintos. Estudo e projeto de acondicionamento da coleção do Museu Paulista da USP. Relatório final de estágio supervisionado, Museu Paulista da USP, 1994. 56p. il. 
O trabalho apresenta o estudo da coleção do museu, sua especificidade quanto a técnicas e materiais, apontando seus principais problemas do ponto de vista da conservação.

A a. apresenta duas propostas de acondicionamento: uma ideal, em termos de mobiliário, materiais e climatização, e outra, em termos possíveis.

São apresentados dois estudos de casos, explicando a opção por materiais e soluções adotadas.

VIBANCOS, Ana Claudia Lopes. Casacas e sobrecasacas. Estudo e projeto de acondicionamento da coleção do Museu Paulista da USP. Relatório final de estágio supervisionado, Museu Paulista da USP, 1994. 59p. il. dat.

O trabalho estuda a coleção de casacas e sobrecasacas do Museu Paulista/USP, apresentando, em detalhes, os principais problemas de conservação detectados e os dois projetos desenvolvidos para seu acondicionamento: um, em termos ideais; outro, em termos possíveis.

São apresentados dois estudos de caso, explicando a opção por materiais e soluções adotadas.

VIBANCOS, Ana Claudia Lopes. Leques. Estudo e projeto de acondicionamento da coleção do Museu Paulista da USP.Relatório final de estágio supervisionado, Museu Paulista da USP, 1995. 2 v. 175p. il. dat.

A autora apresenta um detalhado estudo da coleção de leques do Museu Paulista/USP. O primeiro volume apresenta um histórico dos leques, esclarece suas principais características, diferentes tipologias e nomenclaturas. $\mathrm{O}$ segundo, apresenta cada uma das unidades da coleção, seu estado de conservação e sugere um projeto de acondicionamento .

7. DISSERTAÇÕES DE MESTRADO. 
SILVEIRA, Luciana da. The conservation of two pre-Hispanic Andean tunics: two contrasting approaches. London, 1995. Diploma Report - The Textile Conservation Centre/Courtauld Institute of Arts - University of London. il.

O trabalho da profissional brasileira, avalia a conservação de duas túnicas pré-colombianas pertencentes ao Brighton Museum, Inglaterra, em suas diversas fases.

As túnicas receberam abordagens distintas: a menor, recebeu um tratamento mais extenso, incluindo lavagem aquosa com o uso de aditivos, seguida de costuras de reforço, consolidação e montagem, preparando-a para exposição vertical. A túnica maior, mais frágil, foi submetida a um tratamento de umidificação, menos intervencionista, com suporte para guarda e exposição em plano inclinado.

Segundo afirma a a., o contraste entre as formas de tratamento dos dois objetos, propiciou a análise da dimensão prática de questões éticas ligadas à preservação de evidências históricas presentes em objetos arqueológicos.

\section{PUBLICAÇÕES LATINO-AMERICANAS}

\section{COMITE NACIONAL DE CONSERVACION TEXTIL (Chile). Boletim Informativo, 1990. 18p.il.}

Este primeiro boletim do Comitê chileno, formado em 1987, apresenta os objetivos do grupo, suas atividades, projetos propostos e seis pequenos textos de diversas autorias: Etica en la Conservación, Conservación Preventiva en Textiles, Patrimonio Textil Arqueológico, El Patrimonio Historico en Chile, Textiles Etnograficos Zona Sur e El Textil, complemento de la Imaginería Religiosa.

Cada um dos textos procura discutir as principais idéias a eles associadas, destacando, sempre, a importância dos têxteis na cultura andina ,com ênfase à região chilena. 
MUSEO NACIONAL DE ANTROPOLOGIA Y ARQUEOLOGIA. Los textiles precolombinos y su conservación. Lima: UNESCO/PNUD, [1977]. 37p. il.

O catálogo, de autoria ignorada, reúne quatro estudos. O primeiro discute as origens e o desenvolvimento da arte têxtil; o segundo dedica-se ao estudo dos têxteis na América Pré-Colombiana. O terceiro estuda os têxteis no Peru pré-hispânico e o quarto é dedicado à Conservação de têxteis.

Discutindo brevemente os principais problemas de preservação enfrentados por objetos têxteis, o artigo narra o processo de criação do Centro de conservação têxtil no Museu Nacional de Antropologia e Arqueologia do Peru. Com o auxílio do PNUD/UNESCO foi realizado, em 1977, o primeiro curso de Conservação de Têxteis daquele país, com a duração de seis meses. As matérias do curso foram agrupadas em : Arqueológicas, Museográficas e Especialidades Têxteis.

Finalizando, o catálogo apresenta, em três páginas, informações sobre os procedimentos básicos da conservação de têxteis, aponta alguns materiais a serem evitados em armazenagem e exposição, indicando, ainda, alguns cuidados a serem tomados durante tratamentos por meio aquoso.

\section{LEVANTAMENTOS BIBLIOGRÁFICOS}

COOK, Philippa; DEVITT, Cliodna, orgs. Bibliography on the use of adhesives in Textile Conservation. Trabalho não publicado, The Textile Conservation Centre- Courtauld Institute of Arts - University of London, 1991-1992. 12p.

A pesquisa desta bibliografia foi realizada pelas a. sob orientação de Dinah Eastop, Conservator Tutor, do The Textile Conservation Centre (TCC). As publicações encontram-se reunidas por ordem cronológica de edição e apresentam breves comentários sobre seus conteúdos e utilidade enquanto material de apoio. 
10. DOCUMENTAÇÃO/LAUDOS TÉCNICOS

LORD, Allyn. Condition reports, textiles. s.l. South Eastern Registrars Association - SERA, 1988. p. 47-53.

Este texto é dirigido àqueles profissionais que trabalham exclusivamente, ou não, com a documentação de objetos têxteis. Nele, encontram-se descritos os principais cuidados a serem tomados em relação aos critérios utilizados para avaliar os danos existentes nos objetos.

A a. apresenta um glossário de termos definidores de estragos e defeitos mais encontrados em têxteis históricos, indicando o termo têxtil como definidor de uma grande variedade de objetos, que vão dos tecidos planos e seus produtos, aos não-tecidos (nonwovens).

\section{ARMAZENAGEM E ACONDICIONAMENTO}

BEAUDOIN-ROSS, Jacqueline; BURNHAM, Eva. Recent Trends in Costume and Textile Storage, Suplemento ao Textile Conservation Newsletter, Spring 1990, Canadian Museum of Civilization/ Canadian Conservation Institute, 15p. il.

Este trabalho é consequência do projeto de expansão e renovação do sistema de armazenagem do MCCord Museum of Canadian History, de Montreal, iniciado em 1987. O museu abriga a segunda maior coleção de indumentária do país que, em sua maioria, é composta por trajes e vestes de 1763 até os nossos dias.

Em sua primeira parte, são analisadas as vantagens e desvantagens dos sistemas de armazenagem compacta-deslizante. Os a.contataram 19 instituições museológicas que utilizam esse sistema e verificaram, por exemplo, que nenhuma delas relatou a ocorrência de problemas com poeira, risco de incêndio ou infestação por insetos. Entretanto, várias apresentaram problemas com os efeitos da vibração sobre os têxteis, ocasionada pelo movimento das unidades. 
Na segunda parte as a. fazem um balanço da bibliografia disponível sobre o assunto e terminam por destacar a importância da troca de experiência entre os profissionais e/ou instituições de todo o mundo a respeito de problemas e soluções encontradas para sistemas de armazenagem de coleções têxteis.

\section{BLUM, Stella. Costume preservation and conservation. New York: Metropolitan Museum Of Art - Costume Institute, [1980], 10p. il.}

O texto é destinado a profissionais que trabalham com acondicionamento de coleções de indumentária. O manual limita-se a discutir os materiais adotados para armazenagem de trajes e acessórios daquele Instituto. São apresentadas, em anexo, as especificações técnicas dos materiais utilizados.

\section{LAMBERT, Anne M. Storage of textiles and costumes: guidelines for decision making. Vancouver: University of British Columbia-Museum of Anthropology. 1983, 125p.il.}

Este trabalho é resultado de um projeto de pesquisa desenvolvido pela Universidade de British Columbia, com o objetivo principal de desenvolver métodos satisfatórios para armazenagem de têxteis que - ao contrário do que normalmente ocorre - facilitassem e estimulassem o acesso de pesquisadores e interessados às coleções a serem preservadas.

A a. afirma, na introdução do trabalho, que nenhum sistema de armazenagem de têxteis consegue ser ideal, devido à grande variedade de formas nas quais eles se apresentam . Entretanto, complementa a a., os processos de planejamento e tomada de decisão podem ser bem sucedidos, desde que os principais detalhes do conceito de boa armazenagem sejam considerados em conjunto com as necessidades específicas e recursos de cada instituição.

$\mathrm{O}$ estudo discute, em detalhe, cada etapa a ser trabalhada em um projeto de planejamento de reserva técnica. As principais opções são discutidas uma a uma, assim como cada um dos sistemas e design técnicos mais eficientes.

O trabalho apresenta, ainda, métodos de avaliação do projeto a ser desenvolvido e indica extensa bibliografia de apoio. 
NORTON, Ruth E. Storage and display of textiles (for museums in SouthEast Asia). Paris: UNESCO, s.d. 61p. il. (Studies and Documents on the Cultural Heritage, 8).

Este manual é dirigido a curadores e conservadores sem treinamento na área de conservação de têxteis. Seu objetivo, segundo a a., é evitar que a pouca informação dos profissonais induza em erro e ocasione danos irreversíveis aos objetos.

As possibilidades básicas de armazenagem e exposição são apresentadas e ilustradas em detalhe, com linguagem simples e direta. $\mathrm{O}$ trabalho não apresenta discussões teóricas sobre os procedimentos técnicos; apenas indica soluções corretas, de baixo-custo, que dispensam ou ignoram o uso de equipamentos mais sofisticados.

\section{TÊXTEIS EM EXPOSIÇÃO}

STOLOW, Nathan. Conservation and exhibition: packing, transport, and environmental considerations. London: Butterworth-Heinemann, 1987. 266p. il.

Este livro, que integra a Butterworth-Heinemann Series in Conservation and Museology, destina-se a orientar profissionais de museus envolvidos com atividades de exposição, sobre as especificidades da conservação das várias tipologias de objetos.

Em todos os ítens abordados - embalagem, transporte, fatores ambientais, etc - os têxteis encontram-se mencionados, sendo fornecidas algumas recomendações específicas e imagens de soluções adotadas nas diferentes atividades.

\section{CIÊNCIA TÊXTIL}


GOHL E.P.G.; VILENSKY, L.D. Textile Science: an explanation of fibre properties. Melbourne: Longman Cheshire, 1983. 217p.il.

Dirigido a estudantes da área técnica têxtil, o livro apresenta explicações sobre as propriedades físicas, químicas, tingimento, impressão e beneficiamentos terciários das fibras têxteis. Rico em ilustrações, torna acessíveis as identificações de fibras a olho nu e ao microscópio.

Os conceitos de polímero, fibra e filamento são exaustivamente discutidos na introdução e retomados dentro de cada um dos capítulos: fibras celulósicas, ester-celulósicas, proteicas e sintéticas.

TROTMAN, E.R. Dyeing and chemical technology of textile fibres. 6.ed. London: Edward Arnold ed., 1990.

O trabalho é dividido em dois grandes núcleos. O primeiro descreve a química e as propriedades das fibras têxteis nos processos que antecedem o tingimento. O segundo, descreve os corantes e seus métodos de aplicação. Há, ainda, dois capítulos dedicados a testes e a teoria das cores.

\section{ARTE E TECNOLOGIA TÊXTEIS}

\section{BURNHAM, Dorothy K. Warp and Weft: a textile terminology. Toronto: Royal Ontario Museum, 1954. 216p. il.}

A obra reúne, sob a forma de glossário, a terminologia têxtil, ilustrada e definida, nos idiomas francês, alemão, italiano, português, espanhol e sueco. Ele é resultado de um trabalho iniciado em 1954 com a criação, em Lyon, França, do Centre International d'Étude des Textiles Anciens (CIETA).

Profissionais de diferentes países trabalharam na, até que, em 1974, o grupo de profissionais escandinavos conseguiu publicar o Nordisk Textilteknisk Terminologi, - sistematizando a terminologia utilizada nos países escandinavos na descrição dos processos têxteis do linho e da lã - acrescido do vocabulário já reunido pelo CIETA. O passo seguinte foi a publicação desse trabalho. 
O vocabulário em língua portuguesa, foi trabalhado pela Sra. Maria José Taxinha, Conservadora e Restauradora de Têxteis do Instituto José de Figueiredo, em Lisboa, responsável, também, por outros estudos publicados em português.

DANTYAGI, Susheela. Fundamentals of textiles and their care. 4.ed. New Delhi: Orient Longman , 1984. 352p. il.

Este livro foi elaborado para escolares e donas de casa da Índia, em 1959, com o objetivo de fornecer informações detalhadas sobre a boa conservação de tecidos em geral.

Divide-se em quatro áreas básicas: fibras têxteis (incluindo as fibras de animais como o camelo, a lhama, geralmente ignoradas pelas publicações euroamericanas.); estruturas têxteis , que discute como se deve escolher um tecido; lavanderia, que inclui técnicas para diferenciação dos sabões, teoria e método de utilização de reagentes, clareadores, e finaliza com uma explicação especial de como utilizar máquinas e ferros movidos a eletricidade. A última parte, dedica-se aos tratamentos propriamente ditos, que vão dos receituários de remoção de manchas diversas, à listagem dos pigmentos utilizados na India para produção de batik e outros tecidos.

O livro aborda, em detalhe, cada um dos tópicos citados, sistematizando procedimentos de tradição doméstica de uma cultura onde os têxteis são expressão de religiosidade, condição social e tecnológica.

FUNG PINEDA, Rosa. Manual de terminologia textil en espanõl: un estudo comparativo. s.ed., 1990. 90p. il.

Este estudo comparativo foi realizado pela a. quando de sua participação no Encuentro Regional de Expertos sobre Conservación de Textiles Precolonbinos, realizado em Arica, Chile, em 1990, por iniciativa do PNUD (Projeto Regional de Patrimônio Cultural e Desenvolvimento)/UNESCO.

Seu trabalho teve como fonte de análise o tratado de Irene Emery (1966), The Primary Structures of Fabrics: an ilustrated classification, que foi largamente utilizado por arqueólogos e antropólogos peruanos em seus trabalhos 
de classificação de estruturas têxteis. A partir dele, a a. elabora uma terminologia têxtil em espanhol, cotejando a maioria dos termos com as definições apresentadas no trabalho de Irene Emery. Em toda sua análise, a a. procura levar em consideração as especificidades das culturas andinas e o vocabulário tecnodescritivo na língua espanhola.

Segundo a a.,o termo têxtil pode ser utilizado para nomear todas as estruturas tecidas de um ou mais elementos de qualquer material ou fibra.

SENAI/CETIQT. Diretório de artigos técnicos traduzidos: setor têxtil e de confecção. Rio de Janeiro: Senai/Cetiqt, 1990. 53p.

O diretório reúne referências de 800 artigos traduzidos pelo Serviço de Tradução do Núcleo Setorial de Informação Têxtil e de Confecção.

Os artigos encontram-se agrupados nos seguintes setores de especialização: ciência de polímeros; fibras; fios; tecidos; química têxtil; confecção; análises; testes e controle de qualidade; engenharia; administração; organização e métodos; treinamento e educação; pesquisas; assuntos diversos.

THE TEXTILE INSTITUTE. Identification of textile materials. 7.ed. Manchester, The Textile Institute, 1985. 262p. il.

O trabalho, publicado pela primeira vez em 1951, oferece informação teórica e visual para a identificação de materiais têxteis. Suas características estruturais encontram-se descritas em detalhe, acompanhadas de uma grande série de fotomicrografias, organizadas por tipologia.

São apresentados, ainda, os principais esquemas de análise e métodos de identificação de materiais têxteis, disponíveis, hoje.

\section{QUESTÕES PONTUAIS}

CARPENTER, Jane; HATCHFIELD, Pamela. The problem of formaldehyde in Museum Collections. In: Textile treatments revisited. 
Washington: Washington National Museum of American History/Smithsonian Institution, 1986. p. 35-39.

$\mathrm{O}$ artigo discute os efeitos do formaldeído sobre as coleções museológicas, a partir de pesquisa desenvolvida durante estágio dos a. nos Harvard University Art Museums.

Através de questionário respondido por 93 instituições americanas, verificaram-se possíveis danos causados aos objetos pela ação do formaldeido presente em madeiras utilizadas em mobiliários de armazenagem e exposição. Dentre as instituições envolvidas no projeto, seis apresentaram relatórios que evidenciam a deterioração dos objetos, em sua maioria orgânicos.

FONTARIGO, José. Corantes Sintéticos (para fibras celulósicas e proteicas). Apostila do curso Introdução à conservação e restauração de têxteis antigos e/ou históricos, realizado pelo CETIQT/SENAI. Rio de Janeiro, 1987. 44p.

$\mathrm{O}$ a. apresenta um breve histórico da atividade do tingimento, explicita o conceito de cor e descreve os principais processos de tingimento de fibras celulósicas e proteicas.

SIMPSON, Loern Palmer. Abrasiveness of certain backing fabrics for supporting historic textiles. Journal of the American Institute for Conservation, n.30, p. 179-185, 1991.

A a. apresenta o resultado de suas pesquisas sobre o efeito abrasivo de alguns tecidos de algodão utilizados para suporte de têxteis históricos. A metodologia da pesquisa é descrita em detalhe e são apontadas as principais conclusões sugeridas pelos testes realizados.

\section{TEXTOS DE DIFUSÃO}

ROCKLIFF, Doreen; BROOKS, Mary M.; CLIPSON, Jackie A. Teaching and learning preventive conservation: the TCC postgraduate 


\section{textile conservation diploma In: SEMINÁRIO DA ASSOCIAÇÀO BRASILEIRA DE CONSERVADORES E RESTAURADORES DE BENS CULTURAIS - ABRACOR, 7, Petrópolis, 1994. Anais. Rio de Janeiro, ABRACOR, 1994. p.201-205.}

O texto discute os métodos de ensino utilizados pelo The Textile Conservation Centre (TCC), Surrey, Inglaterra, em seu curso de pós-graduação em Conservação de Têxteis. As várias atividades técnico-científicas desenvolvidas pelo Centro são apresentadas tópico a tópico.

\section{CONSERVAÇÃO DE TÊXTEIS POR TIPOLOGIA}

- RENDAS

EARNSHAW, Pat. Bobbin \& needle laces: identification \& care. London: B\&T Batsford, 1983. 191p. il.

A a. inicia seu trabalho definindo Renda como uma forma de têxtil. Segundo P. Earnshaw, o têrmo têxtil, hoje, pode ser usado para classificar qualquer tecido flexível construído a partir de fios. Um têxtil, afirma, pode ser formado por um único fio, por um conjunto de fios, ou por vários grupos de fios.

Um grande número de ilustrações de estruturas rendadas acompanha a análise histórica das diferentes tipologias. Ao final do trabalho, a a. sugere alguns procedimentos de higienização e introduz a discussão sobre os diferentes padrões da cor branca, em diferentes períodos históricos.

Segundo a a., não podemos submeter uma renda branca do século XVI, por exemplo, a uma lavagem aquosa com detergentes comerciais. Não podemos assumir tal procedimento, afirma, não porque eles possam trazer ao têxtil elementos indesejáveis à sua preservação, mas porque estes introduzirão no objeto, necessariamente, branqueadores ópticos que lhe darão características branco-azuladas, que uma renda, com essa datação, não poderia conter.

Para a a., os diferentes tons de branco existentes nos séculos XVI, XVII, XVIII e XIX são bastante difíceis de serem estabelecidos ou reestabelecidos. 
Registros do século XVIII, referem-se a diferenças nos preços das rendas de acordo com o nuance de branco desejado.

\section{- TÊXTEIS CELULÓSICOS}

FLORIAN, Mary-Lou; KRONKRIGHT, Dale P.; NORTON, Ruth E. The conservation of artifacts made from plant materials. Marina Del Rey: The Getty Conservation Institute, 1992. 332p. il.

A idéia desta publicação surgiu após a realização pelo The Getty Conservation Institute, de um curso de seis semanas sobre conservação de artefatos de matéria-prima vegetal. Três de seus professores foram então convidados a sistematizar as informações sobre o tema e produzir este trabalho.

Os dois primeiros capítulos, de autoria de Mary-Lou Florian, conservator-scientist, introduzem ao Conservador, a anatomia e morfologia das plantas, permitindo, assim, que os profissionais possam melhor identificá-las e melhor compreender suas composições químicas. Incluem-se, aqui, também, as instruções para atividades em Laboratório.

O terceiro capítulo, é de responsabilidade de Ruth Norton, Conservadora com experiência de trabalho nos Museus do Havaí, Filipinas e Austrália (Canberra), e especialista no estudo dos principais métodos e técnicas conhecidos na construção de artefatos de matéria-prima vegetal.

O quarto capítulo, de autoria de Dale Konkright - atual Conservador Senior de Objetos no Pacific Regional Conservation Center - Bernice Pauauhi Bishop Museum de Honolulu,- discute a deterioração enquanto processo. $\mathrm{O}$ a. sistematiza os principais fatores envolvidos, apontando a dificuldade em estabelecerem-se parâmetros gerais - uma vez que os materiais de origem vegetal deterioram devido a vários fatores que atuam simultaneamente sobre eles, em níveis diversos, e que dependem, sempre, das condições ambientais às quais ficam expostos, aos tipos de tecido vegetal que os formam e seu design. Estes fatores determinarão, necessariamente, suas alterações de ordem física, mecânica e química .

O último capítulo, também de autoria de Ruth Norton, enfatiza a importância da não intervenção em objetos etnográficos, sempre que possível. 
Alguns tratamentos são discutidos pela a., e são sugeridos , também, alguns procedimentos para situações consideradas críticas.

A publicação traz ainda quatro apêndices: Como realizar reparos com papel de fibra de mulberry (tipo amoreira), Construção de Caixas e folders para armazenagem; Tabela de adesivos e suas características; Informação sobre o tingimento de materiais celulósicos com corantes reativos.

-MATERIAIS MODERNOS

KOZLOSKI, Lillian; BAKER, Mary T.; MCMANUS, Ed. Space suits, a legacy of America's space program: their evolution and conservation problems. In: ICOM COMMITTEE FOR CONSERVATION, 10th Triennial Meeting. Preprints. Washington, 1993, p. 308-313.

$\mathrm{O}$ artigo dos conservadores e cientista do National Air and Space Museum e Conservation Analytical Laboratory (CAL), ambos unidades da Smithsonian Institution, apresenta uma breve descrição técnica dos trajes espaciais e explicita a natureza dos fatores que atuam em seu processo de degradação. Os a. concluem ressaltando a necessidade atual e futura de se desenvolverem projetos de pesquisa na área de indumentária espacial e/ou produzida com materiais modernos e/ou especiais.

- BANDEIRAS

LEWIS, G.M.; MUIR, N.T.; YATES, N.S. The link between the treatments for paintings and the treatments for painted textiles. In: INTERNATIONAL RESTORERS SEMINAR. Hungary, 1983, p. 169182.

Os a. discutem possíveis semelhanças entre tratamentos de pinturas de cavalete e têxteis pintados, à partir da análise de aproximadamente 750 bandeiras da coleção do National Maritime Museum, Greenwich.

São discutidos os principais tratamentos utilizados para essa tipologia de têxteis e analisados os limites e alcance do uso de adesivos. Em anexo, os a. 
apresentam um apêndice onde estão compilados os adesivos e consolidantes mais utilizados na conservação de têxteis e pinturas.

TRAUTMAN Pat. Stabilization and documentation of Connecticut's State battle flags: one aproach to the presentation of an entire collection. In: FLAG SYMPOSIUM, Harrisburg, Pennsylvania Capitol preservation committee, Oct. 1987.

O artigo apresenta o trabalho de conservação desenvolvido com uma coleção de mais de 160 bandeiras de batalha, de propriedade do estado de Connecticut, Estados Unidos.

Cada um dos parâmetros de abordagem adotados é indicado e analisado do ponto de vista ético-metodológico. Também encontram-se descritos todos os procedimentos de estabilização físico-química dessa coleção de objetos

\section{-TAPETES}

MYERS, George Hewitt et al. Rugs: preservation, display and storage. Principles of practical cleaning for old and fragile textiles. Museum News technical Supplement. s.d. (Washington, The Textile Museum).

O texto, impresso pela primeira vez em 1952, como parte de uma série de vinte quatro Workshop Notes, apresenta os métodos de conservação de tapetes usados por aquele museu americano. São examinadas questões relativas ao acesso aos objetos, recomendam-se alguns processos de fumigação e são sugeridos cuidados para seu transporte.

A segunda parte da publicação apresenta, brevemente, os procedimentos de limpeza mecânica de têxteis fragilizados e sugere alguns testes para determinação das condições desses objetos frente a uma eventual lavagem por meio aquoso e/ou solvente.

- SUPORTES MULTIMIDIA

NEWMAN, Jerri; LEVEQUE, Margaret; SMITH, Leslie. An interspecialty approach to the conservation of multi-media objects: the 
conservation of a collection of fans. In: THE AMERICAN INSTITUTE FOR CONSERVATION OF HISTORIC AND ARTISTIC WORKSPreprints. Vancouver, British Columbia, 1987, p. 85-98.

Os a., respectivamente, Conservador de Papel, Conservadora de Objetos e Conservadora de Têxteis, descrevem o trabalho multidisciplinar desenvolvido na conservação de 150 leques da coleção do Museum of Fine Arts de Boston.

$\mathrm{O}$ artigo resume as principais etapas desenvolvidas, as posturas éticometodológicas adotadas em diferentes situações, avaliando vantagens $e$ dificuldades do trabalho em suportes multimídia.

-INDUMENTÁRIA MILITAR

STORCH, Paul. Military leather objects in the South Carolina State Museum collections: manufacture, condition and treatment. Columbia, South Carolina State Museum, s.d. 7p.

O artigo apresenta os principais problemas de conservação encontrados em objetos feitos total ou parcialmente em couro, em situação permanente de armazenagem.

São discutidas algumas medidas profiláticas, do ponto de vista da administração da coleção, não sendo apresentado, entretanto, nenhum estudo de caso.

18. ÁREAS CORRELATAS

- METAL

CONSERVATION OF METALS: problems in the treatment of metalorganic and metal-inorganic composite objects. International Restorer Seminar. Veszprém, Hungary, jul. 1989. 
Dentre os trabalhos que integram a publicação, foram destacados, aqui, apenas aqueles que abordam direta ou indiretamente os objetos têxteis.

1. Hanna Jedrzejewska, Ethical problems in the conservation of composite metal objects. p.25-26. Neste artigo, a a. discute alguns dos problemas de ordem ética apresentados pelos tratamentos de conservação de objetos que contenham elementos metálicos. Segundo afirma, tais objetos, do ponto de vista de sua conservação, dividem-se em dois grupos: aqueles cujas partes metálicas podem ser removidas e tratadas em separado, e aqueles cujo tratamento deve desenvolver-se em presença de outros materiais.

A a. sugere que, somente após uma pesquisa exaustiva, o conservador avalie os prós e contras apresentados pelos diferentes encaminhamentos práticos, evitando, com isto, que evidências documentais do objeto venham a perder-se.

2. Norman Indictor, Mary Ballard, The effects of aging on textiles that contain metal: implications for analysis. p. 67-75. As a. discutem, neste artigo, os principais fatores que afetam a preservação de têxteis que contenham metal em sua composição. As a. sugerem cinco categorias classificatórias para têxteis que contenham metal: 1. Têxteis com metal aplicado por aderência à estrutura já tecida; 2. Têxteis com fios ou fitas metálicas; 3. Têxteis com fios ou fitas metálicas envolvendo o cerne da fibra; 4. Têxteis com a superfície metálica aplicada por aderência à outra estrutura, orgânica, celulósica ou proteica, que envolve o cerne da fibra; 5. Têxteis com superfície metálica aplicada por aderência a fitas de material orgânico, celulósico ou proteico.

Os a. discutem os tratamentos mais utilizados por conservadores, afirmando que a maioria deles, hoje, não mais se justifica, refletindo ou uma sensibilidade obsoleta ou ignorância por parte dos conservadores, em relação às implicações trazidas pela maioria das intervenções realizadas. Os a. fornecem, ao final do artigo, uma bibliografia específica com 112 títulos.

\section{Eniko Sipos, Erzsébit Gondár, Effect of different treatments on} textiles with metal threads. p. 83-86. São apresentados, neste trabalho, os resultados obtidos pelos a. em sua pesquisa de análise dos principais métodos de limpeza de fios metálicos. Tais métodos, para efeito de análise, oram divididos em dois grupos: aqueles que envolvem tratamentos mecânicos e aqueles quimicamente ativos. 
Os a. analisam os resultados confrontados e sugerem que os tratamentos químicos só sejam utilizados em caso de extrema necessidade, já que o efeito da re-corrosão não pode ser evitado.

4. David Howell, Experiments with chemical cleaning for metal threads. p.87-89. Estudo de caso do trabalho de conservação de um docel pertencente à Câmara de Audiências do Rei, no Hampton Court Palace, Surrey, Inglaterra. Apesar da política definida da instituição ser contra a limpeza de fios metálicos, esta pesquisa foi realizada para evidenciar os aspectos negativos e os positivos desse procedimento. $\mathrm{O}$ texto analisa os testes realizados para identificação do metal e os possíveis efeitos de uma limpeza química sobre o tecido de seda presente no objeto.

5. Luydmila Andreevna Kalinina, The treatment of metal threads in Russian north-European textiles. p. 94. A a. descreve, brevemente, a metodologia de trabalho adotada na limpeza de fios metálicos nas coleções têxteis dos inúmeros museus regionais de Arkhangelsk, Rússia.

6. Marta Járó , Re-corrosion of silver and gilt silver threads on museum textiles after treatment p. 95-98. O artigo apresenta o trabalho de pesquisa da a. sobre a re-corrosão apresentada por objetos têxteis cujos fios metálicos foram limpos, quimicamente, dez ou vinte anos atrás.

\section{CRONYN, Janey M. The elements of archaeological conservation.}

\section{London: Routledge, 1990, 326p. il.}

A a. introduz seu trabalho, salientando que ele foi produzido com a intenção de esclarecer os profissionais não conservadores sobre os principais problemas envolvidos na atividade de conservação arqueológica.

A primeira parte do trabalho apresenta um estudo sobre os diversos agentes encontrados em ambientes arqueológicos, discute o impacto de degradação causado pelas escavações e orienta o trabalho de registro e catalogação do material encontrado.

Em sua segunda parte, o livro aborda todas as tipologias de materiais, orgânicos e inorgânicos, e analisa cada uma quanto a natureza, deterioração, procedimentos para exame, procedimentos de higienização e estabilização. 
- COUROS E PELES

RAPHAEL, Toby J. The care of leather and skin products: a curatorial guide. Leather conservation news: the newsletter journal of treatment and materials research in the specialty of leather conservation, v.9, p. 1-15, [1994].

O guia apresenta as principais características físico-químicas dos couros e peles, os principais agentes atuantes em sua deterioração, sugerindo medidas preventivas e curativas desses materiais. 


\section{conclusão}

Pela concepção pontual e contingencial do tempo, que ninguém se deslumbre com a importância conferida a datas. Em torno destas só há um formigamento de interesses individuais, de paixões não raro inconfessadas que se acendem e se apagam. Os efeitos teatrais que essas paixões ensejam (eventos tão celebrados e identificados por suas datas) na verdade logo foram modificados por outras microconjunturas nas quais novas ou 
velhas motivações se repropuseram ocupando e afinal engolindo os dias que foram passando... Tempus edax, tempo voraz. ${ }^{217}$

A redação deste trabalho foi um exercício surpreendente. Aparentemente as principais idéias, práticas e bibliografia que nortearam as atividades de conservação de têxteis no Museu Paulista da USP foram aqui discutidas. A oportunidade de refletir sobre o próprio trabalho além de mostrar-se bastante proveitosa acabou por transformar-se, ela própria, numa etapa a mais dessa mesma atividade : a ocasião rara a possibilitar o registro daquilo que se pensou, realizou e pretendeu.

Dentro dos limites apontados em cada capítulo foram introduzidas várias idéias diferentes, não consensuais talvez, nem entre os profissionais de conservação no Brasil e no estrangeiro nem na Universidade de São Paulo. Certamente muitas das idéias apenas apontadas, aqui, precisariam ser aprofundadas em outros trabalhos e preferencialmente por outros profissionais.

Esperamos que este ensaio seja entendido futuramente como uma tentativa de iniciar uma discussão que se fazia necessária neste momento histórico e, acima de tudo, como uma possibilidade outra de interpretação das inquietações e da sensibilidade presentes nas atividades de conservação de bens culturais neste fim de milênio.

teresa cristina toledo de paula

Escola de Comunicações e Artes - Universidade de São Paulo - agosto de 1998

${ }^{217}$ Alfredo Bosi, O Tempo e os Tempos IN: TEMPO E HISTÓRIA, op.cit., p.26 


\section{anexo}

documentação do Estudo de Caso 10:

desenhos digitais 